UNIVERSIDADE DE SÃO PAULO

FACULDADE DE ECONOMIA, ADMINISTRAÇÃO E CONTABILIDADE DEPARTAMENTO DE ADMINISTRAÇÃO

PROGRAMA DE PÓS-GRADUAÇÃO EM ADMINISTRAÇÃO

\title{
FATORES DE INFLUÊNCIA NA GERAÇÃO DE PREÇO-PRÊMIO EM E-MARKETPLACES
}

Michael Gomes Van der Linden

Orientador: Prof. Dr. Cesar Alexandre de Souza

SÃO PAULO

2017 
Prof. Dr. Marco Antonio Zago

Reitor da Universidade de São Paulo

Prof. Dr. Alberto Américo Fichmann

Diretor da Faculdade de Economia, Administração e Contabilidade

Prof. Dr. Roberto Sbragia

Chefe do Departamento de Administração

Prof. Dr. Moacir de Miranda Oliveira Júnior

Coordenador do Programa de Pós-Graduação em Administração 


\title{
MICHAEL GOMES VAN DER LINDEN
}

\author{
Michael Gomes Van der Linden
}

\section{FATORES DE INFLUÊNCIA NA GERAÇÃO DE PREÇO-PRÊMIO EM E-MARKETPLACES}

\begin{abstract}
Dissertação apresentada ao Programa de Pós-Graduação em Administração do Departamento de Administração da Faculdade de Economia, Administração e Contabilidade da Universidade de São Paulo, como requisito parcial para obtenção do título de Mestre em Ciências.
\end{abstract}

Orientador: Prof. Dr. Cesar Alexandre de Souza

\section{Versão Corrigida}

(versão original disponível na Faculdade de Economia, Administração e Contabilidade)

SÃO PAULO

2017 
FICHA CATALOGRÁFICA

Elaborada pela Seção de Processamento Técnico do SBD/FEA/USP

Van der Linden, Michael Gomes

Fatores de influência na geração de preço-prêmio em e-marketplaces /

Michael Gomes Van der Linden. - São Paulo, 2017.

$126 \mathrm{p}$.

Dissertação (Mestrado) - Universidade de São Paulo, 2017.

Orientador: Cesar Alexandre de Souza.

1. Comércio eletrônico 2. E-marketplace 3. Reputação 4. Preços I. Universidade de São Paulo. Faculdade de Economia, Administração e Contabilidade. II. Título.

CDD - 658.05678 
Aos meus pais. 


\section{AGRADECIMENTOS}

Aos meus pais, Marta e Haeckel, que me ensinaram desde cedo a importância do estudo e não pouparam esforços para que eu tivesse a oportunidade de ter uma boa educação. Meus pais, assim como meu irmão, Marx, sempre foram apaixonados pela vida acadêmica e os tenho como grandes exemplos na minha formação. Sem eles, com certeza não teria chegado até aqui.

À Camila, pelo enorme apoio e paciência durante o desenvolvimento deste trabalho. Foram incontáveis finais de semana, feriados e até viagens de férias em que não pudemos aproveitar juntos integralmente pois tive que focar nos estudos. Mesmo assim, ela sempre me apoiou. Desde o primeiro dia, ela sempre foi minha maior incentivadora para continuar seguindo sempre em frente.

Aos meus amigos da Equinix, mais especificamente ao Victor Arnaud. Reconhecendo a importância da academia e do meu desenvolvimento pessoal, ele me estimulou a iniciar este Mestrado e possibilitou a flexibilização de horários para que fosse possível conciliar as duas atividades.

Ao Prof. Dr. Cesar Alexandre de Souza por ter acreditado no meu potencial desde o princípio e me acolhido como seu orientando. Foram muitos encontros e discussões que me direcionaram nos momentos mais importantes.

Ao Prof. Dr. Otávio Sanchez da FGV e ao Prof. Dr. Nuno Fouto pelas valiosas observações durante a banca de qualificação. Estendo este agradecimento à Prof. Dr. Adriana Backx e a todos os colegas do grupo de pesquisa e orientação conjunta pelas ideias e sugestões em nossos encontros mensais. 



\section{RESUMO}

VAN DER LINDEN, Michael. Fatores de influência na geração de preço-prêmio em emarketplaces. 2017. 126f. Dissertação (Mestrado). Faculdade de Economia, Administração e Contabilidade da Universidade de São Paulo, São Paulo. 2017.

As plataformas de e-marketplace (EM) atuam como um ponto de encontro virtual, onde vendedores e compradores encontram-se e eventualmente fecham negócios. Em um EM, diversos vendedores competem entre si anunciando ao mesmo tempo produtos exatamente iguais por preços possivelmente diferentes. No entanto, não necessariamente o anúncio mais barato é o que realiza a venda. Dado que nos anúncios publicados nestas plataformas há um grande conjunto de elementos sob responsabilidade do operador do EM, iguais entre todos os anúncios, este trabalho busca colaborar com a compreensão dos fatores controláveis pelo vendedor que influenciam na geração de preço-prêmio em e-marketplaces.

A partir da revisão de pesquisas anteriores sobre o tema, foi elaborado um modelo que considera que a geração do preço-prêmio é influenciada pelas características do vendedor (reputação, porte e localização), do anúncio (utilização de recursos multimídia, divulgação, opções de pagamento e entrega, serviço e histórico do anúncio) e do produto (condição e tipo).

Para validar este modelo, foi desenvolvido um programa que ao longo de 56 dias coletou dados reais de vendas de três produtos diferentes (celulares iPhone, videogames Playstation 4 e tênis femininos da marca Osklen) no maior e-marketplace deste tipo no Brasil. Estes dados foram analisados e utilizados para a verificação de nove hipóteses, base do modelo proposto.

Como resultado observou-se que a reputação que o vendedor construiu ao longo das vendas anteriores mostrou-se como um importante fator de influencia. Vendedores com boa reputação conseguem vender com preços maiores, assim como vendedores com pior reputação são penalizados nos valores de suas vendas. O porte dos vendedores influencia positivamente até certo ponto. Existem vendedores de grande porte que, possivelmente se beneficiando dos ganhos de escala, praticam preços menores. A localização do vendedor é relevante no preço da venda e esta relevância varia de acordo com o produto. Também há diferença na influência de acordo com o produto para a utilização de recursos multimídia e para o envio da nota fiscal junto ao produto. Pagar por um pouco mais de exposição que o oferecido por padrão pela plataforma gratuitamente permitiu a realização de vendas com preços maiores, mas o efeito oposto foi observado quando pagou-se pela máxima exposição possível. Também venderam por valores mais altos os anúncios mais antigos e os que ofereceram frete gratuito.

Palavras-chave: comércio eletrônico, e-marketplace, reputação, preços 
VAN DER LINDEN, Michael Gomes. Factors that influence premium price generation in e-marketplaces. 2017. 126f. Dissertação (Mestrado). Faculdade de Economia, Administração e Contabilidade da Universidade de São Paulo, São Paulo. 2017.

\begin{abstract}
E-Marketplace (EM) platforms are virtual meeting points where sellers and buyers can meet and eventually close a deal. In an EM, various sellers compete against each other offering similar products with different prices. The cheapest offer is not necessarily the one that make the sale. As listings published in an EM have a great number of elements controlled by the platform operator, hence equal to all listings. This work aims to understand the factors controllable by the seller that can influence premium price generation in EMs.

Based on the existing literature a model is proposed, in which premium price is influenced by seller characteristics (reputation, size and location), listing characteristics (multimedia resources, exposure, payment and shipping methods, service and ad history) and product (item condition and type).

To validate this model a software was developed to collect real data from the largest retail EM in Brazil. During 56 days sales of three products (iPhone smartphones, Playstation 4 videogame consoles and Osklen female tennis shoes) were watched and stored in a database. This data was analyzed and used for verification of nine hypotheses.

Reputation acquired by a seller with his previous sales was found as an important element influencing the sale price. Sellers with good reputation were able to sell its items by a higher price and sellers with bad reputation had to sell it cheaper. Seller size exerted positive influence to some extent. Big retailers selling in the EM may be able to sell for a smaller price and make profit thanks to the economies of scale. Seller localization is also relevant. The intensity of this relevance varies by product. It was also noticed difference according to the product for the use of multimedia resources and to if the seller says it will provide a tax invoice attached for the sale. Paying to the EM operator for some additional exposure also made it possible for the seller to achieve prices, but the effect was the opposite when the seller paid for the maximum exposure possible. Old listings and listings that offered free shipping also reached higher prices.
\end{abstract}

Keywords: e-commerce, e-marketplace, reputation, prices 


\section{FIGURAS}

Figura 1 - Anúncios similares com preços diferentes no Mercado Livre .............................. 18

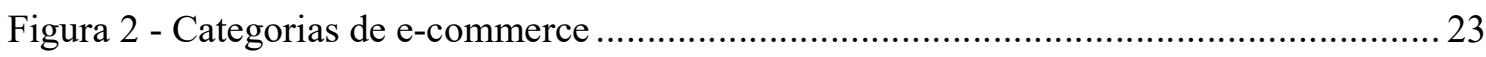

Figura 3 - Classificações de E-marketplaces............................................................... 27

Figura 4 - Fatores de influência em um e-marketplace..................................................... 37

Figura 5 - Seção de reputação em um anúncio...................................................................... 41

Figura 6 - Seção de reputação em um anúncio de vendedor MercadoLíder Gold .................. 42

Figura 7 - Selo de loja oficial que é exibido no topo do anúncio do produto........................ 43

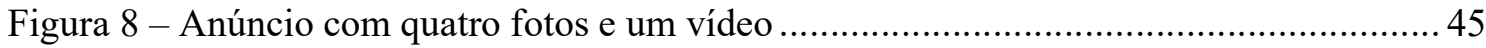

Figura 9 - Seção de garantia do anúncio, com garantia adicional do vendedor de 90 dias..... 46

Figura 10 - Resultado de busca com indicação sobre o frete ............................................ 48

Figura 11 - Exemplo de anúncio que resultou em 319 unidades vendidas .......................... 50

Figura 12 - Primeira abordagem proposta para a coleta de dados ..................................... 58

Figura 13 - Abordagem aperfeiçoada da coleta de dados................................................ 59

Figura 14 - Fluxo de coleta de dados e geração do extrato de vendas................................. 60

Figura 15 - Diagrama de Atividades do programa de extração de dados ................................ 63

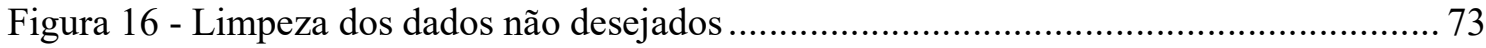

Figura 17 - Distribuição de freqüencia dos preços das vendas de iPhone ............................. 76

Figura 18 - Boxplot dos preços das vendas de iPhones novos e usados.............................. 77

Figura 19 - Variação do preço ofertado dos iPhones nas lojas virtuais tradicionais ............... 78

Figura 20 - Distribuição de freqüência para os preços das vendas de PS4 ........................... 81

Figura 21 - Valores das vendas de PS4 com um controle ou dois controles ........................ 81

Figura 22 - Variação do preço ofertado de Playstation 4 nas lojas virtuais tradicionais ......... 82

Figura 23 - Distribuição de anúncios de iPhone pela quantidade de vendas realizadas .......... 86

Figura 24 - Distribuição de anúncios de PS4 pela quantidade de vendas realizadas .............. 87

Figura 25 - Distribuição de anúncios de tênis pela quantidade de vendas realizadas ............. 88

Figura 26 - Distribuição de vendedores de iPhone pela quantidade de vendas realizadas ...... 92

Figura 27- Distribuição de vendedores de PS4 pela quantidade de vendas realizadas............ 93

Figura 28 - Distribuiçào de vendedores de tênis pela quantidade de vendas relizadas ........... 93 


\section{TABELAS}

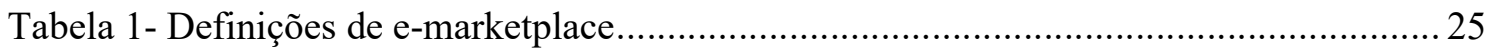

Tabela 2 - Exemplos de E-marketplaces B2C (e C2C) com suas classificações ................... 29

Tabela 3 - Fatores influenciadores do sucesso de um anúncio em um e-marketplace ............ 38

Tabela 4 - Variáveis relacionadas à reputação ............................................................. 41

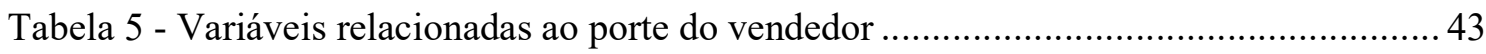

Tabela 6 - Variáveis relacionadas a localização do vendedor ............................................ 44

Tabela 7 - Variáveis relacionadas ao uso de recursos multimídia....................................... 46

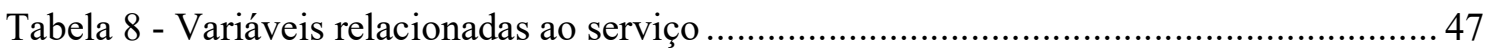

Tabela 9 - Variáveis relacionadas ao pagamento e a entrega........................................ 48

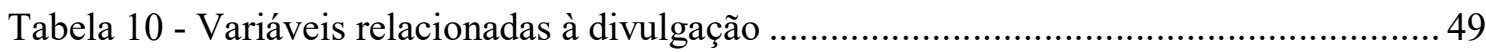

Tabela 11 - Variáveis relacionadas à divulgação .......................................................... 50

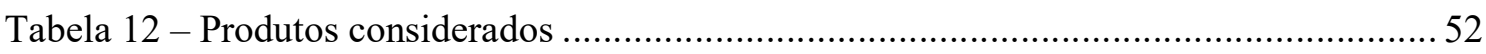

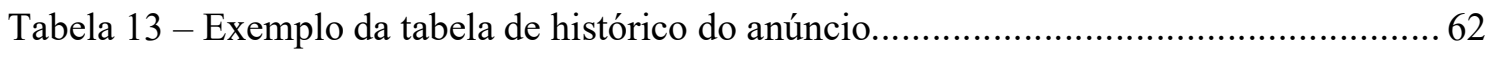

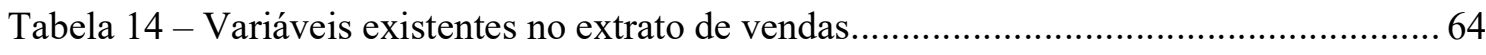

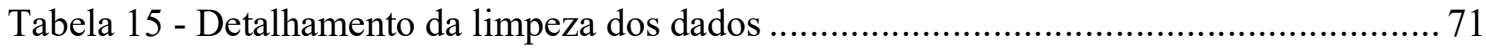

Tabela 17 - Características dos anúncios nas vendas de iPhones ...................................... 74

Tabela 18 - Características dos vendedores nas vendas de iPhones .................................. 75

Tabela 18 - Variação de preços nas vendas de iPhones ...................................................... 76

Tabela 19 - Características do produto nas vendas de iPhones ........................................ 77

Tabela 20 - Características dos anúncios nas vendas de Playstation 4 ............................... 79

Tabela 21 - Características dos vendedores nas vendas de Playstation 4 ........................... 79

Tabela 22 - Variação de preços nas vendas de iPhones ..................................................... 80

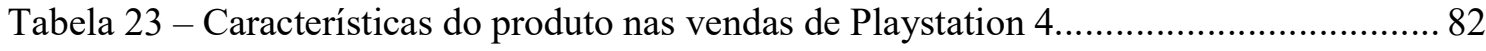

Tabela 24 - Características do produto nas vendas de Tênis ............................................ 83

Tabela 25 - Características do vendedor nas vendas de Tênis.......................................... 84

Tabela 26 - Variação de preços nas vendas de Playstation 4 ............................................ 84

Tabela 27 - Características do produto nas vendas de Tênis .......................................... 85

Tabela 19 - Participação dos anúncios no total de vendas ............................................... 90

Tabela 20 - Participação dos vendedores no total de vendas ............................................. 94

Tabela 30 - Fatores de inflação da variância (VIF) ....................................................... 96

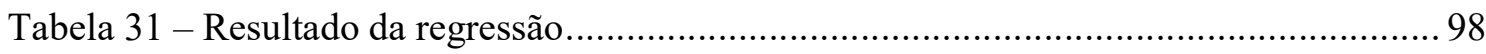





\section{SUMÁRIO}

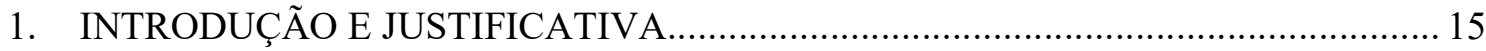

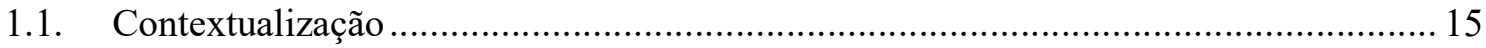

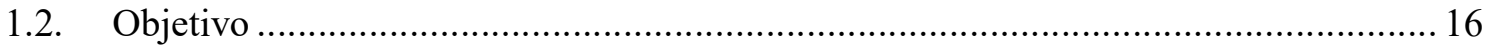

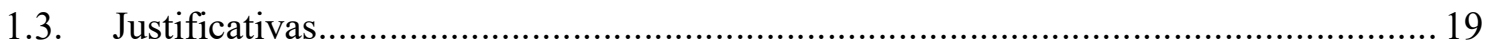

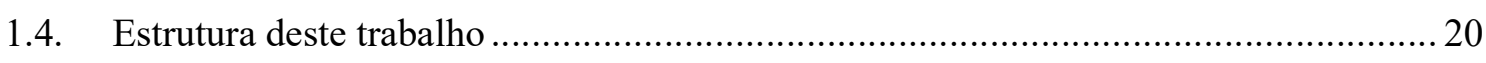

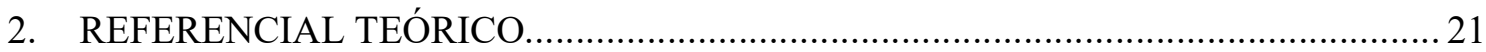

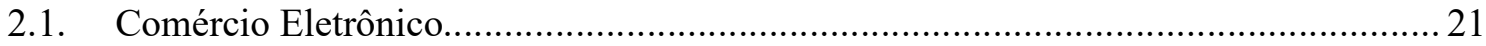

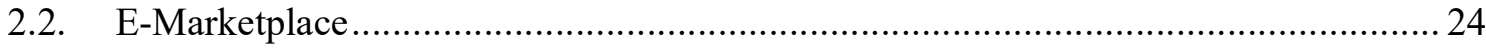

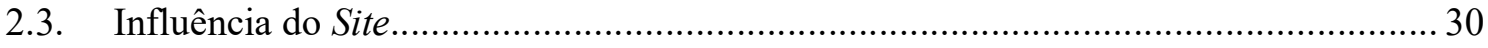

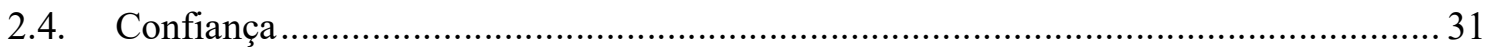

2.5. Fatores de Influência dentro de Marketplace......................................................... 34

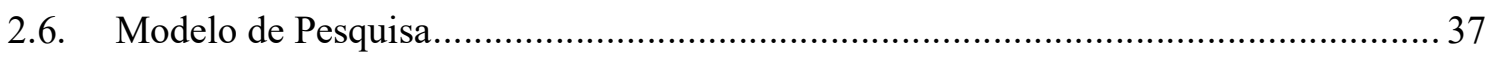

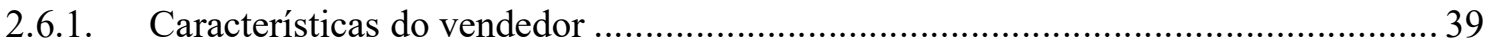

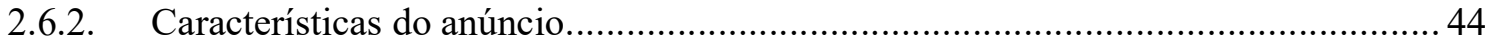

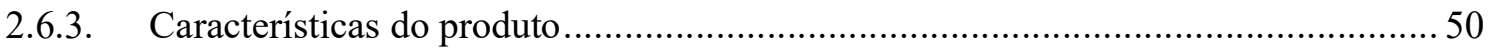

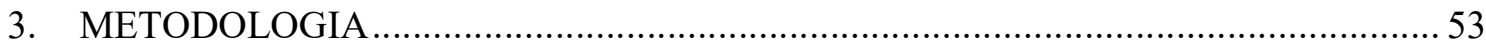

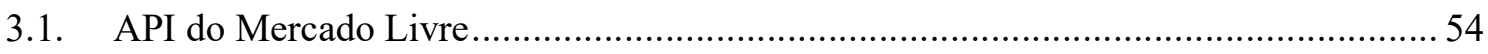

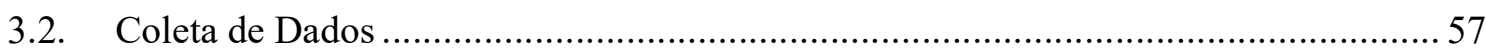

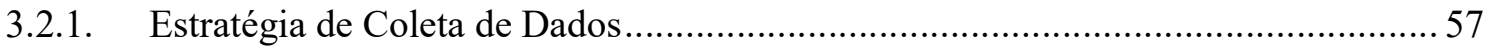

3.2.2. Geração do histórico de anúncios e vendedores................................................. 61

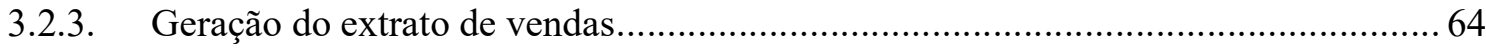

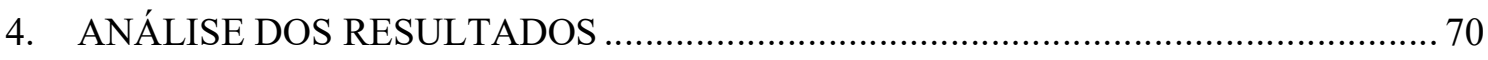

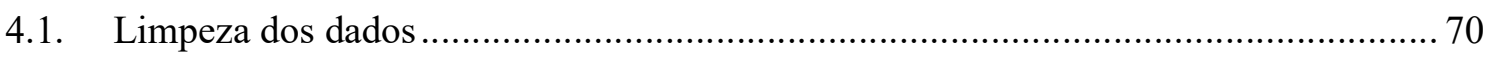

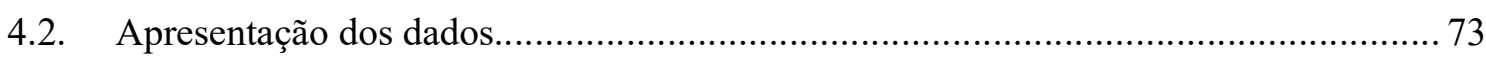

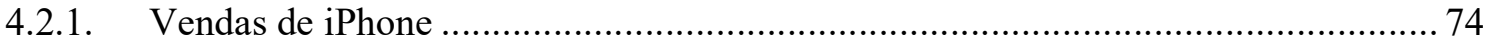

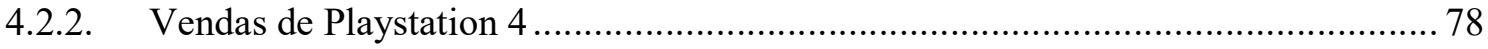

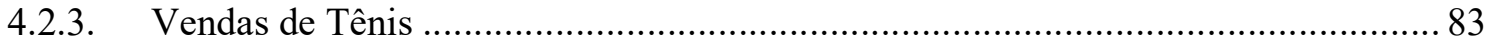

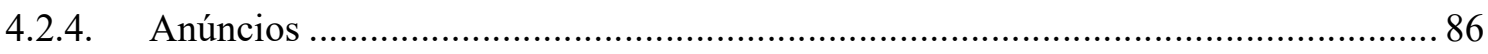

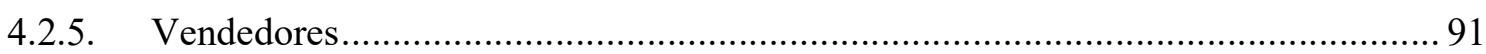

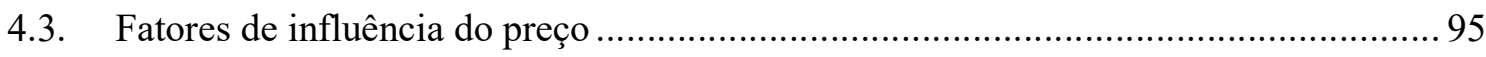

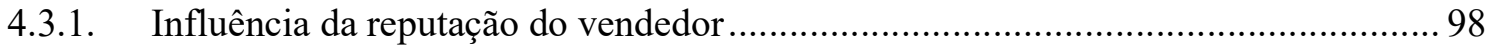

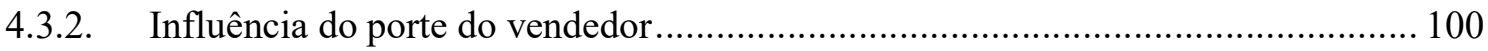

4.3.3. Influência da localização do vendedor......................................................... 101

4.3.4. Influência dos recursos multimídia do anúncio............................................... 101

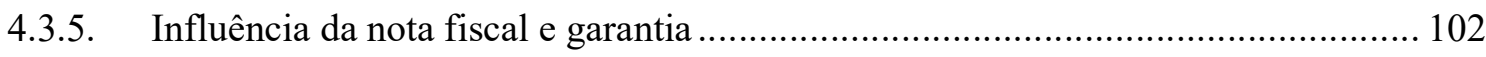




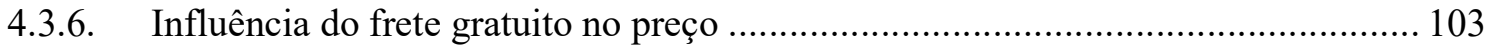

4.3.7. Influência do tipo do anúncio no preço........................................................ 104

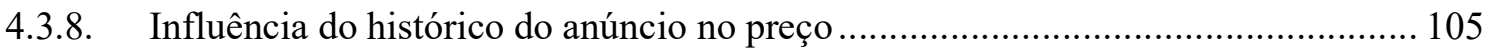

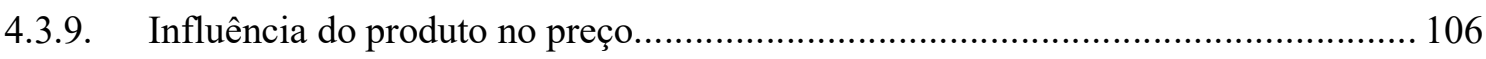

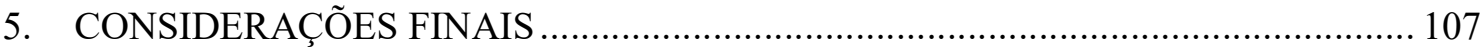

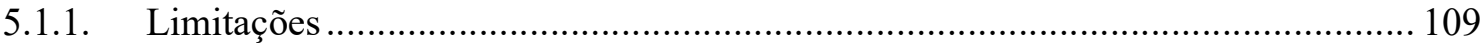

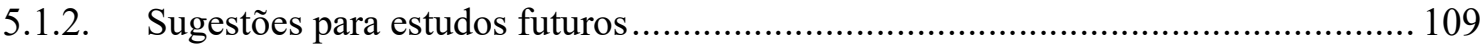

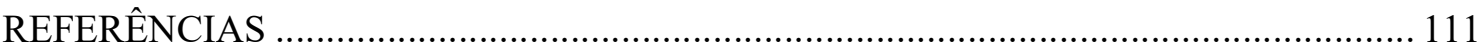

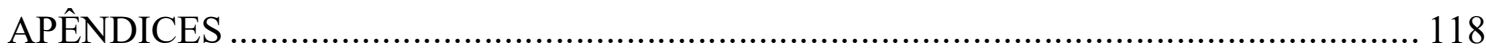




\section{INTRODUÇÃO E JUSTIFICATIVA}

\subsection{Contextualização}

A Internet possibilitou o surgimento das lojas virtuais e tornou mais comum a realização de negócios entre compradores e vendedores localizados em lugares diferentes. Desde então, cada vez mais, os consumidores estão levando em consideração na sua decisão de compra, além das lojas em sua região, a possibilidade de comprar remotamente.

Segundo relatório Webshoppers (EBIT, 2014), em 2001 apenas 1,1 milhões de brasileiros compraram pela Internet. Em 2014, o total de consumidores virtuais no Brasil chegou a 61,6 milhões (EBIT, 2016). O faturamento do varejo eletrônico apresentou um crescimento consistente, acima de dois dígitos percentuais ao ano, em todos os anos desde 2001, inclusive durante os períodos de crise na economia (FECOMERCIOSP, 2015).

O comércio eletrônico mostrou-se uma oportunidade para alçar novos mercados e conquistar novos consumidores, com um investimento inferior ao necessário para o estabelecimento de operações tradicionais, presenciais. Vender pela Internet não exige uma série despesas e investimento comuns às lojas físicas, como aluguel de pontos comerciais em locais disputados e contratação de equipe de vendedores.

Mas, apesar do comércio eletrônico ter simplificado ou eliminado diversas atividades do varejo tradicional, ele trouxe consigo novos desafios. Na Internet o consumidor assume simultaneamente dois papeis: consumidor em um local de compra e usuário de Tecnologia da Informação (TI). O planejamento de uma loja online e o estudo do consumidor virtual deve, então, levar em consideração estes dois papéis, que são assumidos simultaneamente (CHO e PARK, 2001).

Neste cenário, observa-se o surgimento de um modelo de negócios denominado e-marketplace (EM). Trata-se de empresas que oferecem um ponto de encontro online, no qual vendedores e compradores podem interagir, expor suas intenções de compra e venda, negociar preços e eventualmente fechar negócios, geralmente pagando uma comissão por isso (GRIEGER, 2003). 
Apesar de existir crescente literatura sobre este tema, não há um consenso em relação a nomenclatura adotada. Alguns autores preferem se referir a este conceito por outros termos, como online marketplace, e-hub ou plataforma. Esta diversidade de conceitos é justificada por tratar-se de um fenômeno novo e em desenvolvimento. É natural que os termos adotados também evoluam, como já aconteceu com outros conceitos da área de sistemas da informação (WANG e ARCHER, 2007).

Ao longo deste trabalho adotaremos o termo e-marketplace (EM) para se referir ao modelo de negócios ou ao operador e chamaremos de plataforma o sistema que suporta o e-marketplace.

Os operadores do EM atuam como intermediários, agregando a demanda dos compradores e a disponibilidade de produtos dos vendedores, aplicando mecanismos que promovam a confiança, facilitando o mercado para reduzir custos operacionais e formando pares de compradores-vendedores (BAILEY e BAKOS, 1997). Os EMs podem se estender para além de um catálogo de produtos ou ferramentas de leilão, e oferecer serviços complementares como logística, processamento dos pagamentos (BRUNN, JENSEN e SKOVGAARD, 2002).

Utilizando EMs como o Mercado Livre e o eBay qualquer pequena empresa e até pessoas físicas podem realizar vendas pela Internet de forma bastante simples. Pequenas livrarias dos EUA, por exemplo, estavam sofrendo com a proliferação das grandes redes e com a concorrência das lojas virtuais nos anos 1990. Com a inauguração da Amazon Marketplace, estes pequenos comerciantes tiveram a oportunidade de ofertar seus itens para milhares de potenciais clientes (RITALA, GOLNAM e WEGMANN, 2014). No Brasil, sites como o Submarino e a Saraiva possuem plataformas similares ao Amazon Marketplace.

Empresas de maior porte também podem se interessar em vender através dos EMs. Este é o caso de empresas como a Centauro e o Extra, que além de operarem sua própria loja virtual, realizam vendas através dos EMs do Submarino e do Mercado Livre, respectivamente.

\subsection{Objetivo}

Vender em um EM traz duas complexidades principais. A primeira, amplamente abordada na literatura, é conseguir fazer com que duas partes que possivelmente nunca interagiram anteriormente e não tornarão a interagir no futuro, confiem no sistema e na outra parte o 
suficiente para fechar um negócio (BA e PAVLOU, 2002; PAVLOU e GEFEN, 2004; KIM e AHN, 2007; PAVLOU e GEFEN, 2004; VERHAGEN, SELMAR e YAO-HUA, 2006). A segunda é o entendimento de como os vendedores que atuam em um EM, concorrendo entre si, vendendo produtos similares, podem se diferenciar e alcançar melhores resultados (LI, FANG, et al., 2015).

Este trabalho busca justamente explorar esta segunda linha de pesquisa. Dado que a maioria dos elementos relacionados ao EM não está sob o controle do vendedor, procura-se entender quais fatores podem ser trabalhados pelo vendedor em um EM para que este consiga realizar vendas com valores mais altos.

A pergunta-problema deste estudo é: quais fatores controláveis pelo anunciante influenciam na geração de preço-prêmio em um e-marketplace voltado para consumidores?

Temos os seguintes objetivos específicos:

- Identificar na literatura aspectos relacionados a precificação em e-marketplaces.

- Analisar dados por meio de técnicas estatísticas para identificar fatores importantes relacionados a geração de preço prêmio em e-marketplaces.

Gregg e Walczak (2010) definiram preço prêmio em sua pesquisa sobre a influência da qualidade do website e da confiança no preço cobrado em e-marketplaces como o preço recebido por um anúncio de qualidade em relação a um anúncio de baixa qualidade. Neste trabalho, será adotada uma definição similar, mas um pouco mais ampla, incluindo outras variáveis como, por exemplo, as características do vendedor e exploração de recursos da plataforma. Aqui, o preço prêmio será entendido como um preço acima da média cobrada pelos outros anúncios de produtos similares oferecidos na mesma plataforma, no mesmo período.

\subsection{Contexto}

O contexto desta pesquisa são os e-marketplaces de produtos diversos (varejo) que permitem que as vendas sejam realizadas tanto por pessoas físicas quanto por empresas, e cujos preços ofertados são escolhidos pelos vendedores. Mais especificamente, serão verificados os fatores que causam preço prêmio em anúncios similares publicados no Mercado Livre. 
A escolha da realização do estudo nesta plataforma deu-se principalmente pela sua relevância no mercado nacional. O Mercado Livre é o site de comércio eletrônico que mais recebe visitas no Brasil (ALEXA, 2016) e, sozinho, representa mais de $80 \%$ das vendas realizadas em $e$ marketplaces nacionais de varejo (MERCADO LIVRE, 2014). Também contribuiu para a escolha o vasto conjunto de dados disponibilizado pela plataforma, seja através de sua Application Programming Interface ${ }^{1}$ (API) ou diretamente na página do anúncio. É possível obter, por exemplo, além do valor do anúncio, a quantidade de itens vendidos e detalhes sobre o perfil do vendedor (incluindo seu histórico de vendas).

A figura 1 mostra dois exemplos anúncios publicados no Mercado Livre. Trata-se exatamente do mesmo produto (Iphone $616 \mathrm{gb}$ nacional), sendo anunciado na mesma plataforma, no mesmo período, por vendedores diferentes. O valor cobrado em um anúncio é aproximadamente $10 \%$ superior ao outro, mesmo assim, ambos resultaram vendas (o mais barato vendeu 641 unidades e o mais caro 149 unidades).

Figura 1 - Anúncios similares com preços diferentes no Mercado Livre

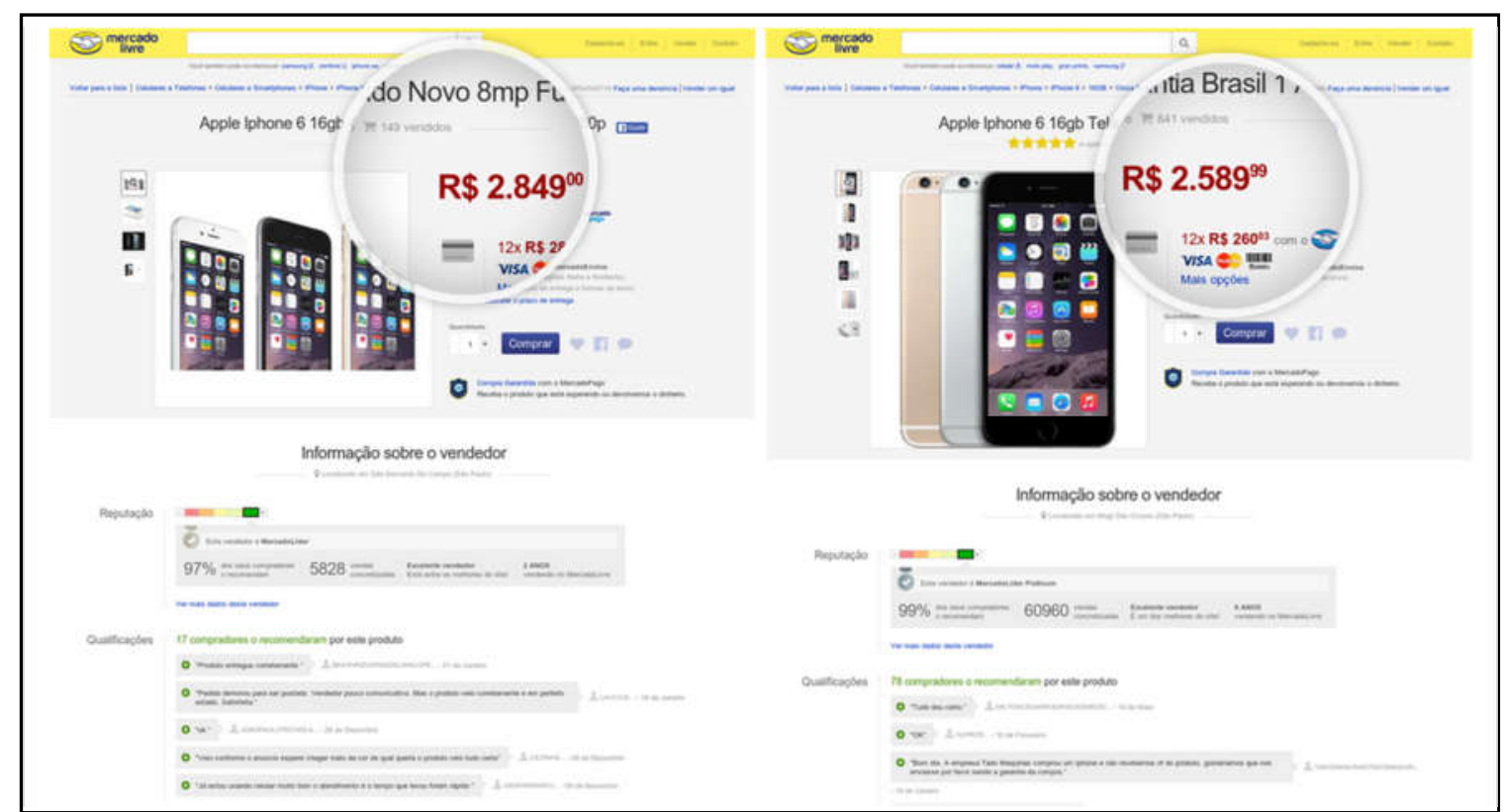

Fonte: adaptado do site do Mercado Livre

\footnotetext{
${ }^{1}$ Uma API é um conjunto de padrões e definições estabelecidas por um software (neste caso, o site do Mercado Livre) para permitir que determinados recursos ou funcionalidades sejam utilizados por outro componente do software ou outra aplicação independente.
} 


\subsection{Justificativas}

A importância dos EMs no e-commerce nacional justifica o interesse prático desta pesquisa. Conforme apresentado na introdução deste trabalho, o comércio eletrônico vem apresentado um volume de vendas significante e com crescimento constante no Brasil. Dentre as diversas modalidades de e-commerce, a realização de vendas através de EMs é bastante representativa, tendo atingido $21 \%$ (6,6 bilhões) de todas as transações realizadas no varejo eletrônico do Brasil em 2012 (EBIT, 2014).

Uma pesquisa realizada pela Nielsen, a pedido do Mercado Livre / Mercado Libre (MERCADO LIVRE, 2014) afirma que 150 mil pessoas na América Latina tiram sua renda exclusivamente através de vendas realizadas em sua plataforma, sendo 51,7 mil microempreendedores e 98,5 mil funcionários destes. No Brasil, são 43,5 mil pessoas vivendo de vendas realizadas no Mercado Livre.com.br. Compreender quais fatores podem ser trabalhados para aumentar suas chances de sucesso pode influenciar diretamente na vida destas. O operador do EM também pode se beneficiar dos resultados deste estudo para aprimorar os recursos existentes em sua plataforma.

Do ponto de vista teórico, a relevância deste trabalho justifica-se pela ausência estudos semelhantes no mercado nacional. Foram feitas buscas no Scielo, Google Acadêmico e portal de periódicos da Capes pelos os termos "e-marketplaces", "marketplace" e "mercados eletrônicos" e "Mercado Livre". Há diversas publicações sobre o assunto, mas nenhuma trata exatamente do objetivo deste trabalho. Entre os temas cobertos pelas pesquisas nacionais estão as estratégias de publicidade adotadas pelo e-marketplace (DALZOCHIO e HOFFMANN, 2014), identificação de fraudes nestes mercados (ALMENDRA e SCHWABE, 2009; ALMENDRA e SCHWABE, 2008; ARANZATO, NEUBERT, et al., 2009; MARANZATO, PEREIRA, et al., 2010) e relacionamento e fidelização de clientes em EMs (LEMES, MIRANDA, et al., 2004). Os trabalhos mais próximos encontrados foram os de Pereira, Duarte et al. (2009a, 2009b, 2011). Nestas publicações os pesquisadores exploraram o perfil dos vendedores de EMs brasileiros e estratégias de sucesso adotadas.

Internacionalmente, a maioria dos estudos publicados sobre este tema, até então, foram desenvolvidos a partir de experimentos controlados ou dados obtidos de sites estrangeiros (ADAMS, 2007; HUI, SAEEDI, et al., 2016; LI, LI e LIN, 2008; NETO, CORBETT e 
BLOEMHOF, 2016; ONUR, 2010; RESNICK, ZECKHAUSER, et al., 2006; ZHANG, 2006). Nestes estudos geralmente este assunto é abordado em relação as vendas realizadas por leilão. Esta parece não ser a realidade brasileira. No Mercado Livre, plataforma mais utilizada no mercado nacional, as vendas por leilão representam apenas 3\% do total (MERCADO LIVRE, 2014). Além disso, em trabalhos anteriores geralmente foram estudadas uma ou duas variáveis específicas isoladamente, como por exemplo, a presença de foto, a reputação do vendedor ou o conteúdo do anúncio. Este trabalho busca estudar o comportamento destas variáveis em conjunto.

\subsection{Estrutura deste trabalho}

Este trabalho está estruturado em cinco tópicos. Neste primeiro, há uma introdução ao tema, com a contextualização e apresentação do problema. No capítulo seguinte são apresentados o arcabouço teórico e o modelo que baseia esta pesquisa. O terceiro capítulo trata da metodologia utilizada. Em seguida, no quarto capítulo, há uma análise dos dados e discussão sobre os resultados atingidos. No capítulo final constam as considerações finais, limitações deste trabalho e sugestões de estudos futuros. 


\section{REFERENCIAL TEÓRICO}

A partir de pesquisas sobre publicações nacionais e internacionais sobre os temas, o referencial teórico deste trabalho começa contextualizando o assunto ao apresentar conceitos mais abrangentes sobre comércio eletrônico, para em seguida focar na modalidade deste que é o objeto desta pesquisa: o e-marketplace.

São apresentadas diversas definições de EM existentes na literatura e, como este termo é bastante abrangente, a classificação dos diversos tipos de e-marketplaces proposta por Wang e Archer (2007) é explorada e adaptada para o consumer-to-consumer (C2C). Através de exemplos os conceitos das classificações são reforçados, o tipo de EM representado pelo Mercado Livre é descrito e diferenciado em relação aos demais.

Após esta fundamentação sobre comércio eletrônico e EM, parte-se para exploração dos fatores que influenciam o preço das negociações nestas plataformas. Considerando que um anúncio no Mercado Livre é uma página da Internet em que parte dos seus elementos é controlado pelo EM e parte pelo vendedor, inicia-se a exploração da influência do site e dos seus elementos. Dentre os diversos fatores observados na literatura, há grande ênfase naqueles relacionados à confiança. Tadelis (2016) revisa a literatura para destacar o papel da confiança no comércio eletrônico e, principalmente, em EMs. Por estes motivos, uma seção é dedicada exclusivamente para este assunto.

Finalmente, são explorados outros estudos com objetivos próximos ao deste, para entender como trataram a questão, suas metodologias, objetos e principais achados. Então é apresentado o modelo desta pesquisa e as hipóteses a serem verificadas.

\subsection{Comércio Eletrônico}

Zwass (1996) definiu comércio eletrônico (CE ou e-commerce) como o compartilhamento de informações, manutenção de relações de negócios e condução de transações através de redes de telecomunicações. Em sua definição, o autor considera o intercâmbio eletrônico de dados (EDI: eletronic data interchange) como parte do conceito de CE. 
Kalakota e Whinston (1997) compartilham desta visão e destacam o envio de mensagens (como ordens de compra) entre grandes empresas como a primeira grande expansão do CE. Mas, ainda segundo os autores, foi no início dos anos 1990, com o surgimento da Internet comercial, mais especificamente da World Wide Web (WWW), que o e-commerce passou a apresentar as características que os definem atualmente.

Literaturas mais recentes consideram e-commerce apenas as atividades de compra e venda através da Internet. Turban et al. (2015) definem o termo como o uso de Internet ou intranets para comprar, vender, transportar ou trocar dados, bens ou serviços. Laudon e Laudon (2010) consideram que o e-commerce, como compra e venda de mercadorias e serviços pela Internet, é parte de um conceito mais amplo, o e-business, que é o uso de tecnologia digital para conduzir os negócios da empresa.

O CE pode ser classificado de acordo com as partes envolvidas na transação. As categorias mais comuns são: business-to-consumer (B2C), na qual uma empresa vende para consumidores individuais; o business-to-business (B2B), na qual uma empresa vende para outras empresas; business-to-government (B2G), na qual uma empresa vende para o governo e consumer-toconsumer (C2C), na qual indivíduos compram e vendem entre si, com utilizando de um emarketplace. Há ainda uma categoria para os processos de negócios que dão suporte a venda, como o compartilhamento de informações entre empresas. (SCHNEIDER, 2011)

Turban et al. (2015) ampliam essa categorização para incluir os funcionários da empresa, citando o business-to-employee (B2E), na qual uma empresa disponibiliza produtos e serviços para seus funcionários através da Internet e o government-to-employee (G2E), com os serviços prestados pelo governo aos trabalhadores. Os autores também mencionam partes já citadas, mas no sentido inverso, como por exemplo o consumer-to-business (C2B). A Figura 2 mostra as categorias de e-commerce na visão destes autores. 
Figura 2 - Categorias de e-commerce

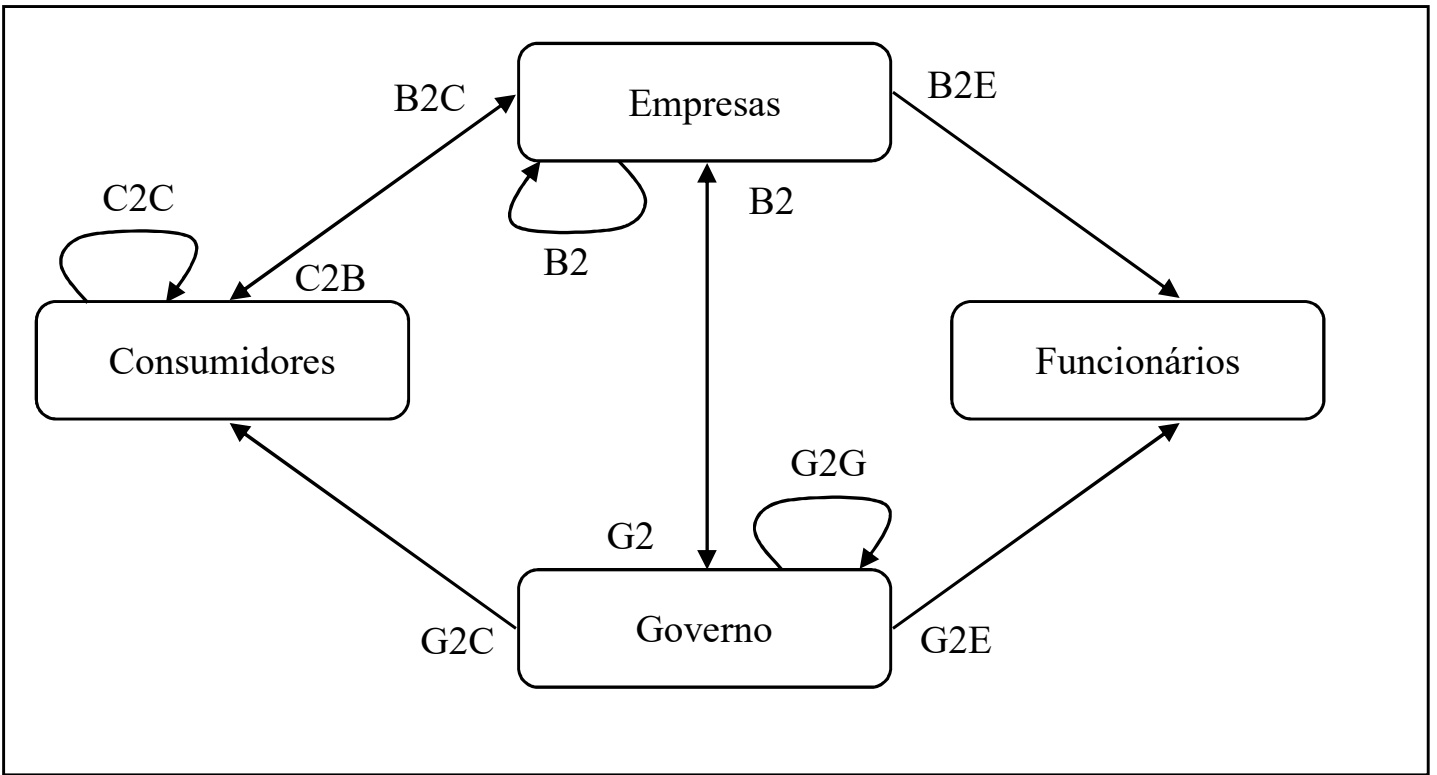

Fonte: Adaptado de Turban et al (2015)

Esta migração de consumidores das lojas físicas para as lojas virtuais pode ser encarada como uma oportunidade, afinal, graças a este movimento qualquer loja, independentemente de sua localização física, pode agora realizar vendas para pessoas de todo o país e até de outros países. (HOFFMAN, NOVAK e CHATTERJEE, 1995)

As grandes redes varejistas, como o Grupo Pão de Açúcar (através da Nova Pontocom), o Magazine Luiza e as Lojas Americanas (através da B2W) estão atentas a este movimento e possuem forte presença on-line. Outras grandes empresas, como a Netshoes e a Dafiti, foram fundadas para atender exclusivamente nesta esta modalidade, e sequer possuem lojas físicas.

No entanto, as pequenas e médias empresas ainda enfrentam dificuldades para vender online. Isto fica evidente quando observamos que $70 \%$ do faturamento do varejo eletrônico do Brasil está concentrado nas 10 maiores empresas (NEXTECOMMERCE, 2015).

Manter uma loja virtual requer recursos e habilidades que muitas vezes está fora do alcance das empresas menores e empreendedores individuais. Atividades intrínsecas ao negócio, como controle de estoque, logística, pesquisa de mercado, suporte ao cliente e publicidade, ganham novas características no mundo on-line. O domínio da tecnologia para desenvolver e operar a loja virtual, respondendo rapidamente às tendências do mercado, é um outro obstáculo. Operar 
na Internet requer um investimento maior e com um retorno em um prazo um pouco mais longo que aqueles geralmente realizados pelas PMEs.

Mas abrir sua própria loja virtual, no entanto, não é a única opção para que uma PME que deseja vender seus produtos pela Internet. Diversas lojas virtuais permitem que outras empresas, ou até pessoas físicas, efetuem vendas através de sua estrutura, cobrando uma comissão por cada venda, em um modelo de negócio conhecido como plataforma ou e-marketplace (EM).

\subsection{E-Marketplace}

Ao se comparar os números das duas maiores lojas virtuais do mundo, a Amazon e o Alibaba (EUROMONITOR INTERNATIONAL, 2017), podem ser observados resultados bem diferentes. Em 2015, o total de vendas realizadas através dos vários sites do Alibaba (U\$398 bilhões) foi substancialmente maior que total vendido através da plataforma da Amazon (U\$225 bilhões). No entanto, a receita reportada pelo Alibaba não é valor total das vendas que ocorrem eu seu site, mas um número bem menor. Comparando a receita das duas operações, temos uma situação inversa: a receita da empresa chinesa (U\$14.7 bilhões) foi uma fração dos mais de U\$100 bilhões reportados pela americana (NASDAQ, 2016).

Isso ocorre pois, apesar de ambas terem como seu principal negócio a operação de uma loja virtual, estas empresas possuem modelos de negócio distintos. Diferente da Amazon, o Alibaba não possui estoque e não vende diretamente produtos para os consumidores. Em todas as vendas que ocorrem em seu website, o Alibaba está apenas conectando um vendedor (que, este sim, possui o produto) a um comprador, e ganhando uma comissão por isso. A receita reportada pelo Alibaba é apenas a comissão por esta intermediação. O restante do valor da venda é considerado apenas uma transação processada pelo seu sistema. A Amazon apesar de também possuir um EM, o que justifica a diferença entre seu total de vendas e a receita, atua principalmente como um varejo tradicional, comprando de fornecedores, estocando e vendendo para consumidores finais.

Grieger (2003) apresenta diversas definições para o termo e-marketplace (EM) existentes na literatura até o ano 2000. O autor destaca a visão do EM como um ponto de encontro online, no qual vendedores e compradores podem interagir, expor suas intenções de compra e venda, 
negociando preços e eventualmente fechando negócios. A Tabela 1 mostra estas definições, complementadas com definições de literatura mais recente.

Tabela 1- Definições de e-marketplace

\begin{tabular}{|c|c|}
\hline Autor & efinição \\
\hline $\begin{array}{l}\text { McCoy e Sarhan } \\
\text { (1998), citado por } \\
\text { Grieger (2003) }\end{array}$ & $\begin{array}{l}\text { "Um EM separa a função da negociação da transferência física do } \\
\text { produto ou commodity que o mercado negocia. Ele pode gerenciar as } \\
\text { ofertas e lances dos compradores e vendedores, independentemente de } \\
\text { sua localização e fornecer informações sobre o mercado para todos os } \\
\text { negociadores em tempo real". }\end{array}$ \\
\hline $\begin{array}{l}\text { Bakos (1991), } \\
\text { citado por Grieger } \\
(2003)\end{array}$ & $\begin{array}{l}\text { "... é um sistema de informação interorganizacional que permite que } \\
\text { vendedores e compradores participantes troquem informações sobre } \\
\text { preços e ofertas de produtos". }\end{array}$ \\
\hline $\begin{array}{l}\text { Bradley e Peters } \\
\text { (1997), citado por } \\
\text { Grieger (2003) }\end{array}$ & $\begin{array}{l}\text { “...pode ser visto como uma listagem pública de produtos e seus } \\
\text { atributos de todos os fornecedores de um segmento da indústria e } \\
\text { disponível para todos os potenciais compradores". }\end{array}$ \\
\hline Bak & $\begin{array}{l}\text { "...facilitando a troca de informação, bens, serviços e pagamentos. No } \\
\text { processo, criam valor econômico para compradores, vendedores, } \\
\text { intermediários do mercado e para a sociedade como um todo" }\end{array}$ \\
\hline $\begin{array}{l}\text { Schmid (1998), } \\
\text { citado por Grieger } \\
(2003)\end{array}$ & $\begin{array}{l}\text { "... é uma mídia que alimenta trocas baseadas no mercado entre } \\
\text { agentes em todas as fases da transação." }\end{array}$ \\
\hline $\begin{array}{l}\text { Segev (1999), } \\
\text { citado por Grieger } \\
(2003)\end{array}$ & $\begin{array}{l}\text { "Comparado com muitas outras soluções de aquisição eletrônicas, } \\
\text { EMs representam uma posição relativamente entre compradores e } \\
\text { vendedores, provendo serviços para ambos os lados em uma transação. } \\
\text { Um EM representa um local virtual onde vendedores e compradores se } \\
\text { encontram para trocar bens e serviços". }\end{array}$ \\
\hline $\begin{array}{l}\text { Dai e Kauffman } \\
\text { (2000), citado por } \\
\text { Grieger (2003) }\end{array}$ & $\begin{array}{l}\text { "...funciona como intermediários digitais que focam em verticais da } \\
\text { indústria ou funções de um negócio específico. Eles configuram } \\
\text { marketplaces onde empresas participam de atividades de compra e } \\
\text { venda após obterem uma filiação". }\end{array}$ \\
\hline
\end{tabular}




\begin{tabular}{|c|c|}
\hline $\begin{array}{l}\text { Mueller (2000), } \\
\text { citado por Grieger } \\
(2003)\end{array}$ & $\begin{array}{l}\text { "Mercados eletrônicos possibilitam que compradores e vendedores } \\
\text { troquem informações sobre ofertas de produtos, preços pedidos e } \\
\text { valores ofertados.". }\end{array}$ \\
\hline $\begin{array}{l}\text { Ariba (2000), } \\
\text { citado por Grieger } \\
(2003)\end{array}$ & $\begin{array}{l}\text { “... são sites de comércio na Internet pública que uma grande } \\
\text { comunidade de compradores e vendedores se encontrem e negociem } \\
\text { entre si. Eles apresentam estruturas ideais para trocas comercial, } \\
\text { atingindo novos níveis de eficiência de mercado ao aproximar e } \\
\text { automatizar o relacionamento entre comprador e vendedor.”. }\end{array}$ \\
\hline $\begin{array}{lr}\text { Kaplan } & \text { e } \\
\text { Sawhney, citado } \\
\text { por } \quad \text { Grieger } \\
(2003)\end{array}$ & $\begin{array}{l}\text { "... é um ponto de encontro onde vendedores e compradores podem } \\
\text { interagir online." }\end{array}$ \\
\hline $\begin{array}{l}\text { Lipis et al. (2000), } \\
\text { citado por Grieger } \\
(2003)\end{array}$ & $\begin{array}{l}\text { “... é uma solução baseada na Internet que conecta negócios } \\
\text { interessados em comprar e vender bens ou serviços uns dos outros. } \\
\text { Pode ser diferenciado de um sistema de aquisição ou distribuição na } \\
\text { medida que ele é neutral, levando em consideração na sua governança } \\
\text { tanto os interesses dos vendedores como dos compradores” }\end{array}$ \\
\hline Le $(2$ & $\begin{array}{l}\text { "Um e-marketplace é uma plataforma de comércio eletrônico multi- } \\
\text { party que intermedia negócios entre compradores e vendedores" }\end{array}$ \\
\hline $\begin{array}{l}\text { Hagiu (2007), } \\
\text { citado por Ryan, } \\
\text { Sun e Zhao (2012) }\end{array}$ & $\begin{array}{l}\text { "Estes marketplaces servem como uma plataforma de dois lados, no } \\
\text { qual um intermediário, ou empresa de marketplace, provê o serviço de } \\
\text { formação de pares de vendedores e compradores, enquanto o controle } \\
\text { sobre bem é deixado com o vendedor" }\end{array}$ \\
\hline $\begin{array}{l}\text { Wang e Archer } \\
(2007)\end{array}$ & $\begin{array}{l}\text { "Marketplaces eletrônicos são lugares onde compradores e vendedores } \\
\text { conduzem transações por meios eletrônicos. Esses lugares podem ser } \\
\text { físicos, virtuais ou conceituais. EMs podem ser representados por } \\
\text { diferentes termos." }\end{array}$ \\
\hline Li et al (2015) & $\begin{array}{l}\text { "E-marketplaces são plataformas de transações online hospedadas por } \\
\text { um terceiro para facilitar as trocas entre compradores e vendedores } \\
\text { (ex.: Amazon e Taobao)". }\end{array}$ \\
\hline
\end{tabular}

Fonte: adaptado de Grieger (2003)

Os operadores do EM assumem o gerenciamento de toda a infraestrutura tecnológica da loja virtual e investem em publicidade para atrair os consumidores. Em alguns casos o EM também 
é responsável por intermediar o pagamento. Às pessoas ou empresas que desejam efetuar vendas através da plataforma, cabem atividades como controle de estoque e envio do produto ao cliente (ou prestação do serviço).

Nesse conceito, podemos incluir uma enorme variedade de empresas que, não necessariamente, competem entre si. O Ifood é um exemplo de e-marketplace, que conecta restaurantes e consumidores. O Airbnb conecta donos de imóveis que estão ociosos e viajantes.

Wang e Archer (2007) revisaram a literatura para entender as definições e classificações dos emarketplaces. Apesar do foco de seu trabalho ter sido os EMs de business-to-business (B2B), as classificações sugeridas pelos autores são gerais o suficiente para explicar os diversos tipos de EMs existentes, incluindo aqueles que serão abordados nesse trabalho, os B2C e os C2C. A Figura 3 resume as classificações que são descritas nos parágrafos seguintes.

Figura 3 - Classificações de E-marketplaces

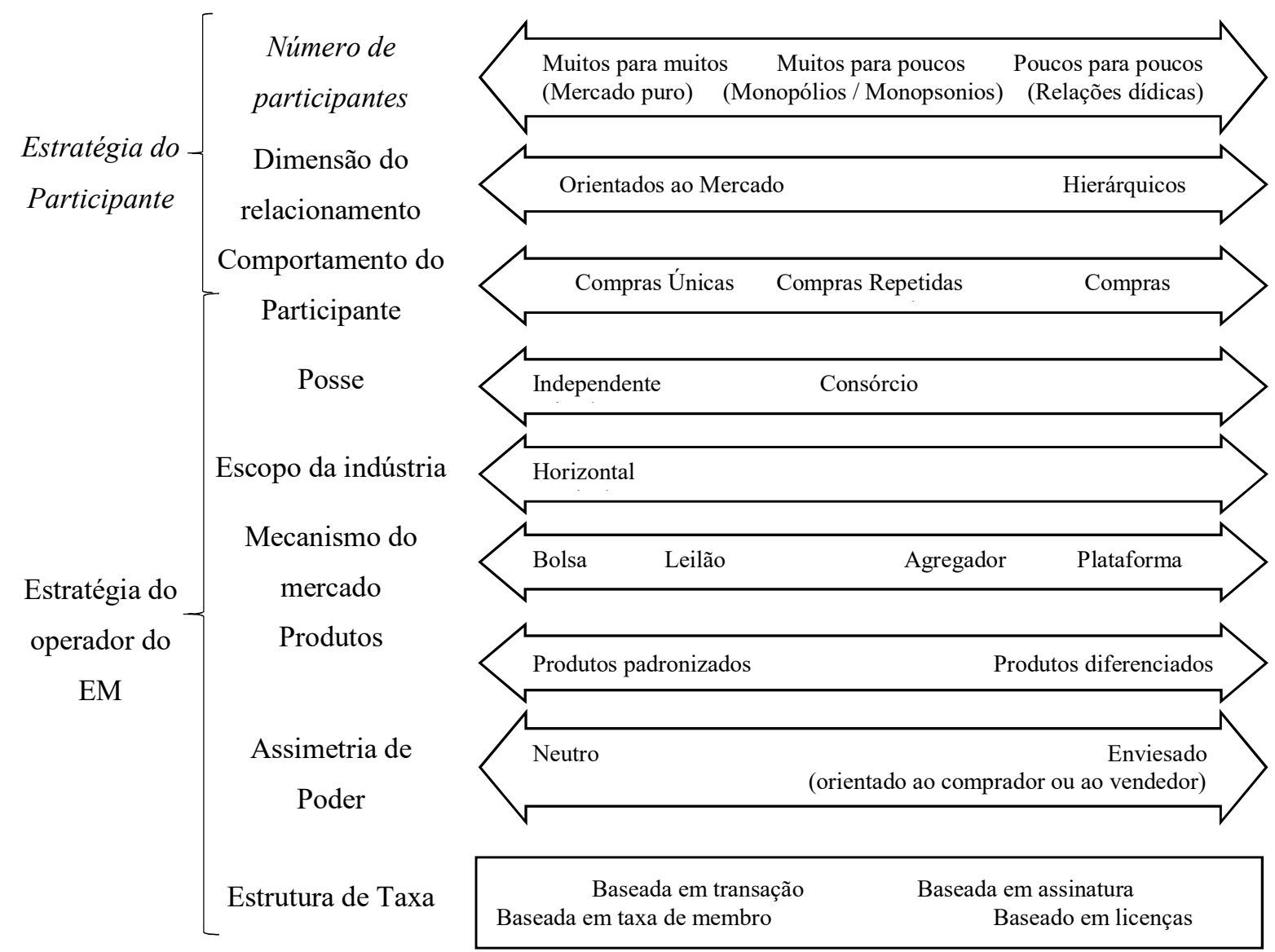

Fonte: adaptado de Wang e Archer (2007) 
Segundo estes autores, os EMs podem ser classificados de acordo com o número de participantes, dimensão do relacionamento entre eles, comportamento do participante, posse do EM, escopo da indústria, mecanismo do mercado, produtos, assimetria de poder e estrutura de taxa.

Em relação ao número de participantes, um EM com muitos participantes (muitos compradores e muitos vendedores) também pode ser chamado de mercado puro, pois promove a competição entre as partes. É mais comum encontrar estas características nos EMs B2C ou C2C. Outras configurações, com menos participantes, são mais comuns em mercados específicos B2B ou EMs privados, e podem priorizar um relacionamento mais hierárquico, com processos e aprovações.

Ainda segundo Wang e Archer (2007), o comportamento dos participantes pode ser pontual, com compras únicas, ou seja, formando um novo par de fornecedor e comprador a cada transação. Mas em alguns cenários, geralmente aqueles que tratam de B2B, pode ser interessante não gerar uma nova negociação (e aprovação) a cada transação. Um único cruzamento de fornecedor com comprador pode resultar em vendas repetidas.

Um EM voltado para o consumidor, geralmente é operado por uma empresa independente, que está apenas conectando as partes mas não está agindo (comprando ou vendendo) diretamente. Mas é possível que uma empresa, ou um consórcio de empresas, crie uma plataforma própria especificamente para atender às suas necessidades. Neste caso, é possível que haja uma assimetria de poder intencional, que pode ser classificada como orientado ao comprador ou orientado ao vendedor.

Quanto ao escopo, diz-se que este é horizontal quando a plataforma é utilizada para vender diversos produtos, que podem ser utilizados por várias indústrias ou pessoas, ou verticais quando estão focados em uma indústria específica. Estes produtos podem ser padronizados ou diferenciados.

Além do que é negociado, também há diferenças no mecanismo utilizado, ou seja, em como ocorre a negociação. É possível que esta ocorra como em uma bolsa (com preços sendo definidos em tempo real através de ordens de compra e venda), como catálogos, leilão ou plataforma colaborativa. 
Finalmente, um EM pode ser classificado de acordo com a forma em que ele cobra seus participantes. A forma mais comum é a cobrança de um percentual de cada transação, mas outras formas também são possíveis, como a cobrança de taxas de membro, licenças ou a venda de serviços adicionais.

A partir desta classificação, a Tabela 2 mostra alguns exemplos de e-marketplaces $\mathrm{B} 2 \mathrm{C}$ e C2C nacionais e internacionais e como eles são categorizados em relação a cada aspecto. A tabela foi elaborada a partir da consulta dos sites de cada plataforma. Destaca-se o Mercado Livre, objeto deste trabalho, como um e-marketplace orientado ao mercado, no qual muitos vendedores interagem com muitos compradores para a realização de transações únicas (não repetitivas) através de leilões ou preços fixos (catálogos). $\mathrm{O}$ vendedor determina seu preço e constrói seu anúncio, descrevendo seu produto ou serviço com informações textuais, fotos ou vídeos. Para cada venda, o vendedor paga uma comissão ao Mercado Livre.

Tabela 2 - Exemplos de E-marketplaces B2C (e C2C) com suas classificações

\begin{tabular}{|c|c|c|c|}
\hline Exemplo & Descrição & $\begin{array}{l}\text { Estratégia do } \\
\text { Participante }\end{array}$ & Estratégia do Operador \\
\hline \multirow{6}{*}{$\begin{array}{lr}\text { Mercado } & \text { Livre } \\
\text { (Brasil), } & \text { eBay } \\
\text { (EUA) e } & \text { Taobao } \\
\text { (China) } & \end{array}$} & \multirow{6}{*}{$\begin{array}{l}\text { Permite a postagem de } \\
\text { anúncios de produtos e } \\
\text { serviços por pessoas e } \\
\text { empresas (C2C ou } \\
\text { B2C). O vendedor } \\
\text { personaliza } \\
\text { anúncio escolhendo o } \\
\text { texto, fotos e vídeos. A } \\
\text { venda pode ocorrer } \\
\text { com preço fixo ou } \\
\text { como leilão. }\end{array}$} & $\begin{array}{l}\text { Participantes: Muitos } \\
\text { para Muitos }\end{array}$ & Posse: Independente \\
\hline & & $\begin{array}{l}\text { Dimensão: Orientado } \\
\text { ao Mercado }\end{array}$ & Escopo: Horizontal \\
\hline & & $\begin{array}{l}\text { Comportamento: } \\
\text { Compras únicas }\end{array}$ & $\begin{array}{l}\text { Mecanismo: Leilão e } \\
\text { agregador (catálogo) }\end{array}$ \\
\hline & & & Produtos: Ambos \\
\hline & & & $\begin{array}{l}\text { Assimetria de Poder: } \\
\text { Neutro }\end{array}$ \\
\hline & & & $\begin{array}{l}\text { Taxas: Baseada em } \\
\text { transação e recursos } \\
\text { extras (publicidade) }\end{array}$ \\
\hline $\begin{array}{l}\text { Amazon } \\
\text { Marketplace }\end{array}$ & $\begin{array}{l}\text { Permite que empresas } \\
\text { anunciem seus }\end{array}$ & $\begin{array}{l}\text { Participantes: Muitos } \\
\text { para Muitos }\end{array}$ & Posse: Independente \\
\hline
\end{tabular}




\begin{tabular}{|c|c|c|c|}
\hline $\begin{array}{l}\text { (EUA), Submarino } \\
\text { Marketplace }\end{array}$ & $\begin{array}{l}\text { produtos na loja virtual } \\
\text { do operador do }\end{array}$ & $\begin{array}{l}\text { Dimensão: Orientado } \\
\text { ao Mercado }\end{array}$ & Escopo: Horizontal \\
\hline \multirow{4}{*}{$\begin{array}{l}\text { (Brasil) e Extra } \\
\text { Marketplace } \\
\text { (Brasil) }\end{array}$} & \multirow{4}{*}{$\begin{array}{l}\text { Marketplace. } \\
\text { vendedor não } \\
\text { personaliza a página } \\
\text { do anúncio (há apenas } \\
\text { uma página por } \\
\text { produto, } \\
\text { independentemente da } \\
\text { quantidade de } \\
\text { vendedores). }\end{array}$} & $\begin{array}{l}\text { Comportamento: } \\
\text { Compras únicas }\end{array}$ & $\begin{array}{l}\text { Mecanismo: Agregador } \\
\text { (catálogo) }\end{array}$ \\
\hline & & & $\begin{array}{ll}\text { Produtos: } & \text { Produtos } \\
\text { padronizados } & \end{array}$ \\
\hline & & & $\begin{array}{l}\text { Assimetria de Poder: } \\
\text { Neutro }\end{array}$ \\
\hline & & & $\begin{array}{l}\text { Taxas: Baseada em } \\
\text { transação. }\end{array}$ \\
\hline
\end{tabular}

Fonte: Elaborado pelo autor.

Neste trabalho definiremos EM como lugares onde vendedores e compradores podem se encontrar virtualmente para eventualmente fechar negócios. Os operadores do EM são responsáveis por definir regras e criar um ambiente que facilite a realização das transações. Entre os vários tipos de EM, este trabalho explora aqueles voltados para o consumidor pessoa física (B2C ou $\mathrm{C} 2 \mathrm{C}$ ), com muitos vendedores e muitos compradores negociando ao mesmo tempo, no qual o vendedor é quem determina o preço ofertado, as vendas são do tipo não recorrentes (para cada transação um par de vendedor e comprador é formado) e o comprador é quem escolhe de qual vendedor irá efetuar a compra (a formação do par não é determinada pelo operador).

A seguir são apresentados diversos elementos que podem atuar como diferenciadores para os vendedores em EMs.

\subsection{Influência do Site}

O site é a principal forma de interação entre uma empresa de comércio eletrônico e seus clientes. Por isso, diversos autores destacam a importância deste na estratégia da empresa, quais fatores influenciam na sua qualidade e como estes influenciam no comportamento do consumidor.

Constantinides (2004) apresenta o conceito de Experiência Web (EW). Segundo o autor, em uma loja tradicional, física, existem fatores incontroláveis (culturais, pessoais, sociológicos 
etc.) e estímulos controláveis (mix de marketing tradicional) que influenciam o processo de decisão de compra. Nas lojas virtuais, além destes, há um conjunto de novos fatores controláveis, a EW, que influenciam o comportamento do consumidor e a impressão total que este tem a respeito da empresa on-line. Para o autor, a EW é composta por três blocos: fatores de funcionalidade, fatores psicológicos e fatores do conteúdo.

Segundo Bai, Law e Wen (2008), a qualidade de um website pode ser medida através da sua funcionalidade e usabilidade. Para Aladwani e Palvia (2002) a qualidade de um website pode ser estudada em três dimensões: adequação técnica, conteúdo e aparência. Há ainda autores consideram que a qualidade de um website pode ser medida pela qualidade do sistema, do serviço e da informação (DELONE e MCLEAN, 2003; KIM e AHN, 2007; LIN, 2010). Vila e Kuster (2011) consideraram como fatores de uma loja virtual de sucesso a usabilidade (facilidade de uso e velocidade), o conteúdo (imagem, ofertas, preços), o serviço (frete, formas de pagamento) e a segurança, e enxergaram relações entre estas variáveis e a confiança, a atitude, a satisfação, o risco percebido e a intenção de compra.

Pavlou (2003) propôs um modelo de aceitação de uso de e-commerce por parte dos consumidores, ao integrar confiança e risco no modelo de aceitação da tecnologia (TAM). Diversos outros autores também enfatizam a questão da confiança no comércio eletrônico. Lumsden e Mackay (2006) consideram que embora crítico em qualquer negócio, confiança é especialmente significante no comércio eletrônico, cujas transações são mais impessoais, anônimas e automatizadas.

\subsection{Confiança}

A confiança é um conceito que permeia as nossas relações sociais e humanas. No entanto, por ser abstrata e complexa, a confiança é algo difícil de ser definido. Vários estudos, de diversas disciplinas adotam diferentes definições e formas de operacionalizar seu estudo.

Beldad et al. (2010) revisaram a literatura sobre confiança para compreender os antecedentes da confiança on-line. Os autores encaixaram as distintas abordagens do conceito de confiança em quatro categorias: confiança como uma característica individual, confiança como expectativa, confiança como exposição e aceitação a vulnerabilidades, confiança como um fator institucional e a confiança como um fator racional ou irracional. 
Wang e Emurian (2005) procuraram observar as diversas interpretações de confiança de acordo com a área de pesquisa. Segundo os autores, os antigos filósofos gregos já estudavam a confiança como uma tentativa de definir a natureza humana. Os filósofos modernos consideram em seus estudos a questão moral da confiança e a enxergam como um fator interpessoal. Os psicólogos também seguem esta vertente interpessoal, mas concentram-se principalmente nas diferenças individuais, relacionadas as características pessoais e suas consquências nos relacionamentos sociais.

Ainda estes segundo os autores, na Administração a confiança é observada dentro das organizações, nos relacionamentos inter e intra-organizacionais e como estrutura informal de governança. No Marketing, o estudo da confiança geralmente está relacionado às interações entre os fornecedores com os canais de distribuições e entre os cliente e as empresas. Dentro do marketing há ainda o estudo do marketing de relacionamento, que presta maior destaque no papel da confiança na construção de relacionamentos duradouros, de longo prazo. Há ainda estudos sobre o comportamento do consumidor e como as empresas podem despertar o sentimento de confiança destes.

Comuns a todas estas áreas, está a importância atribuída a confiança. Fundamental em qualquer interação social, a confiança é um fator crítico em qualquer negócio. No comércio eletrônico, onde as transações on-line costumam ser são mais impessoais, anônimas e automatizadas, a confiança é ainda mais significante (LUMSDEN e MACKAY, 2006).

Para que um consumidor se sinta confiante o suficiente para realizar uma compra pela Internet, as empresas precisam construir um ambiente de tecnologia seguro e definir processos que garantam o sucesso das transações. No entanto, apesar da necessidade da infraestrutura técnica segura, ela não é condição suficiente para criação da confiança online. As lojas virtuais precisam desenvolver intervenções que inspirem as atitudes, intenções e crenças dos consumidores (SALAM, LAKSHMI, et al., 2005).

Segundo Corritore et al. (2003), a confiança on-line é resultado de uma combinação entre a percepção do consumidor sobre a credibilidade, o risco e a facilidade de uso de um vendedor virtual. Estes fatores exercem influência entre si, mas também são influenciados por fatores externos, tanto físicos como psicológicos. Estes fatores externos são relacionados tanto ao 
consumidor (ex: sua propensão a confiar em geral e sua familiaridade com e-commerce), quanto ao website (ex: o design da página e a precisão da informação) e a situação (ex: a interação do usuário com o website e seu nível de controle).

Chen e Dhillon (2003) construíram um modelo, com base na literatura, que mostra a influência das características do consumidor, da empresa, das interações entre as partes e da infraestrutura do website como influenciadoras na confiança, que, por sua vez, influencia a intenção de compra.

Diversos outros autores exploraram a influência de fatores específicos na construção da confiança de um consumidor em relação a uma loja virtual. São exemplos de fatores estudados a percepção do consumidor sobre o tamanho da loja (JARVENPAA, TRACTINSKY e VITALE, 2000), referências recebidas e reputação percebida (CORBITT, THANASANKIT e YI, 2003; DELLAROCAS, 2003; TEO e LIU, 2007), o design e as características técnicas do website (WANG e EMURIAN, 2005), características do serviço como a garantia de troca e devolução (CORBITT, THANASANKIT e YI, 2003), a realização de parcerias e a presença de selos de terceiros (CORBITT, THANASANKIT e YI, 2003), a facilidade de aceitação da TI pelo consumidor (GEFFEN, KARAHANNA e STRAUB, 2003).

Estes pontos, que são complexos e desafiadores em comércios eletrônicos convencionais, são ainda mais aguçados nos e-marketplaces. Nos EMs, as pessoas interagem rotineiramente com estranhos, dos quais se tem pouco ou nenhum conhecimento prévio, fazendo com que se tornem vulneráveis a golpes e fraudes aplicados por vendedores maliciosos

Tratando-se de e-marketplaces, podemos considerar a questão da confiança através de duas categorias: a confiança no intermediário e a confiança no vendedor. O intermediário não é diretamente responsável pelo comportamento dos vendedores, mas provê mecanismos institucionais (ex.: mecanismos de reputação, serviços de escrow ${ }^{2}$, garantias de reembolso etc.) para promover a existência da confiança. A crença do consumidor que este intermediário é

\footnotetext{
${ }^{2}$ Em EM que oferecem serviço de escrow, ao invés de efetuar o pagamento diretamente ao vendedor, o comprador realiza o pagamento através da plataforma do EM. Ao invés de repassar imediatamente o valor ao vendedor, o EM espera até que ambas as partes sinalizem que a transação foi bem-sucedida ou que não haja reclamação formal por parte do comprador em um prazo pré-estabelecido.
} 
confiável influencia na confiança em relação ao vendedor e na intenção de compra (HONG e CHO, 2011).

A importância destes mecanismos e outros fatores relevantes nos EMs é discutida na seção seguinte.

\subsection{Fatores de Influência dentro de Marketplace}

Os modelos e teorias que tratam da influência do website na decisão de compra podem ajudar empresas que vendem on-line a compreender quais variáveis podem ser controladas e como otimizá-las para se obter um melhor desempenho. No entanto, tratando-se das empresas que vendem através de EMs, uma série de restrições são impostas pelo operador do EM e nem todas as variáveis podem ser trabalhadas.

Dependendo do formato adotado pelo EM, os vendedores possuem pouca ou nenhuma possibilidade de personalizar o website. Especificamente naqueles que funcionam em formato de leilão ou classificados, como o eBay ou Mercado Livre, há um conjunto de elementos prédefinidos (ex: layout da página no EM, modelo de funcionamento e reputação, aspectos técnicos do site etc.) e outros elementos que podem ser personalizados ou construídos pelo vendedor (ex: seu histórico de reputação, conteúdo de seu anúncio, layout do anúncio, fotos etc.).

Dentro de uma mesma plataforma, diversos vendedores concorrem entre si, apenas trabalhando nestes elementos. Com isso, enquanto algumas características, por serem iguais para todos os vendedores, ganham menor relevância, outras recebem um destaque maior.

As características mais exploradas pela literatura são as relacionadas a confiança, como a importância da reputação e os mecanismos para se fomentá-la em um e-marketplace. Como exemplificado nos parágrafos seguintes, através de diferentes técnicas, diversos autores constataram que consumidores tem maior disposição para comprar em vendedores com melhor reputação, e que vendedores com boa reputação conseguem vender mais unidades e praticar preços maiores.

Ba e Pavlou (2002) afirmam que a reputação do vendedor, medidas através da avaliação de compradores anteriores, tem um importante papel na construção da confiança e na geração de 
preço prêmio. Segundo os autores, o preço do produto (caro ou barato) influencia na importância da reputação, principalmente no impacto de avaliações negativas. Para chegar nestes resultados, um experimento foi conduzido em laboratório, com uma simulação de um site de leilões perfis de vendedores com diferentes avaliações e os participantes responderem perguntas que indicassem o quanto confiavam nos vendedores. Além disso, comprovou-se o estudo coletando-se do eBay dados reais de leilões finalizados e as avaliações recebidas, para diversos produtos.

Bajari e Hortacsu (2003) coletaram dados de transações do eBay para entender os comportamentos do compradores e dos vendedores nos leilões, desenvolvendo um modelo estrutural. Os autores observaram leilões de moedas antigas e compararam com os valores de catálogo delas. Foi constatado que ofertar um item com um valor inicial do leilão elevado afasta participantes, e leilões com menos participantes terminam em valores mais baixos. Outro fator destacado como inibidor de novos participantes no leilão foi a reputação negativa do vendedor.

Segundo Livingston (2005), se um vendedor possui uma boa reputação, as chances de que seu anúncio receba lances, resulte em vendas e tenham um valor acima da média aumenta consideravelmente. $\mathrm{O}$ autor destaca a importância destas avaliações positivas principalmente durante as primeiras vendas, pois o retorno adicional para o vendedor após as primeiras avaliações não é muito forte. Para chegar a estas conclusões, foram coletados dados reais sobre leilões de tacos de golf no eBay.

Jin e Kato (2006) fizeram um estudo sobre a relação entre o preço, a qualidade, a qualidade afirmada pelo vendedor e a reputação do vendedor. Os autores compraram cards colecionáveis de beisebol no eBay, pediram para especialistas avaliarem e compararam com a descrição dada pelo vendedor. Eles concluíram que é menos provável que vendedores com boa reputação não entreguem o produto ou envie falsificações. Mas a qualidade do item não apresenta relação com a reputação.

Resnick et al. (2006) realizaram dois experimentos no eBay com um vendedor experiente e bem avaliado. No primeiro, foi criado um perfil novo para este vendedor e itens semelhantes (cartões postais antigos) foram anunciados no seu novo perfil e no perfil já conhecido. No segundo, foram criados novos perfis e realizadas algumas falsas vendas para se construir uma reputação com nota negativa para alguns deles. Foi constatado que vendedores bem avaliados realmente 
conseguem um preço maior (preço prêmio) que vendedores novos. Para novos vendedores, a avaliação negativa não fez efeito significante (vendedores novos com uma ou duas avaliações negativas não tiveram piores resultados que vendedores sem avaliações)

Przepiorka (2013) trabalhou com um grande volume de dados $(\mathrm{N} \approx 176.000)$ do site alemão do eBay, com anúncios de diversos tipos de cartões de memória, para comprovar que há influência da reputação na probabilidade de venda e no preço da venda, tanto em leilões como em anúncios de preço fixo. Ao considerar os anúncios de preço fixo, o estudo mostra que os vendedores também entendem o valor da reputação. Quanto melhor a reputação do vendedor, maior é o preço que ele anuncia seus itens. Além disso foi observado que a competição (muitos anúncios similares) reduz a quantidade de vendas e que os valores finais de leilões são mais baixos quando estes acabam em finais de semana e mais altos nos leilões de maior duração.

Cabral e Hortaçsu (2010) estudaram o efeito causado pelas avaliações negativas. Vendedores que foram mal avaliados sentem imediatamente um impacto negativo na sua taxa de vendas. Além disso, as avaliações negativas afetam o comportamento do vendedor. Vendedores mal avaliados tem maior chance de deixar de utilizar a plataforma. Bente et al. (2012) mostram que a ausência de avaliações pode ser mais prejudicial ao vendedor que reputações negativas.

Pavlou e Dimoka (2006) acrescentaram que, além da nota recebida pelo vendedor, o conteúdo textual da avaliação é relevante. Utz et al. (2009) seguiram nesta linha de análise do que está sendo dito na avaliação, mas observaram que o conteúdo da resposta do vendedor também é relevante e pode influenciar na reconstrução de uma reputação.

Mas a reputação não é o único fator influenciador na taxa de vendas e no preço cobrado por um vendedor em um EM. Gregg e Walczak (2010) mostram, inclusive, que vendedores que constroem um website (anúncio) de qualidade são igualmente percebidos como confiáveis, independentemente de suas avaliações. Bente et al. (2012) destacam, além da reputação, que boas fotos podem resultar em mais vendas. Neto, Bloemhof e Corbett (2016) mostraram que a descrição do produto influencia no seu preço de venda, e que esta influência é maior nos produtos usados, que nos remanufaturados e nos novos. Melnik e Alm (2005) também mostram que características dos produtos são relevantes neste contexto. Estes autores verificaram que quando os há mais incerteza em relação a qualidade dos itens vendidos, a reputação do vendedor ganhar maior importancia. 
A maioria destes estudos que investigam os fatores que influenciam o sucesso de um anúncio em uma plataforma de e-marketplaces como o eBay ou o Mercado Livre está voltada ao formato específico de leilão. Nestes casos, também são considerados fatores como a duração do leilão, o preço inicial, o valor de incremento entre os lances, a existência de preço de reserva e opção de buy it now para verificar a influência destes no preço final do leilão e na quantidade de vendas (ADAMS, 2007; BAPNA, JANK e SHMUELI, 2008; FUCHS, EYBL e HÖPKEN, 2011).

\subsection{Modelo de Pesquisa}

A partir dos conceitos apresentados, pode-se observar os principais fatores que influenciam no sucesso de um anúncio em um e-marketplace, quando comparado com outro anúncio do mesmo produto, anunciado na mesma plataforma. Estes fatores estão relacionados a características do vendedor, do anúncio ou do produto e formam a base para este modelo de pesquisa (Figura 4).

Neste trabalho, observa-se os fatores que influenciam geração de preço prêmio em uma venda (realização de venda com um preço acima do preço médio). Em nosso modelo, esta é a variável dependente.

Figura 4 - Fatores de influência em um e-marketplace

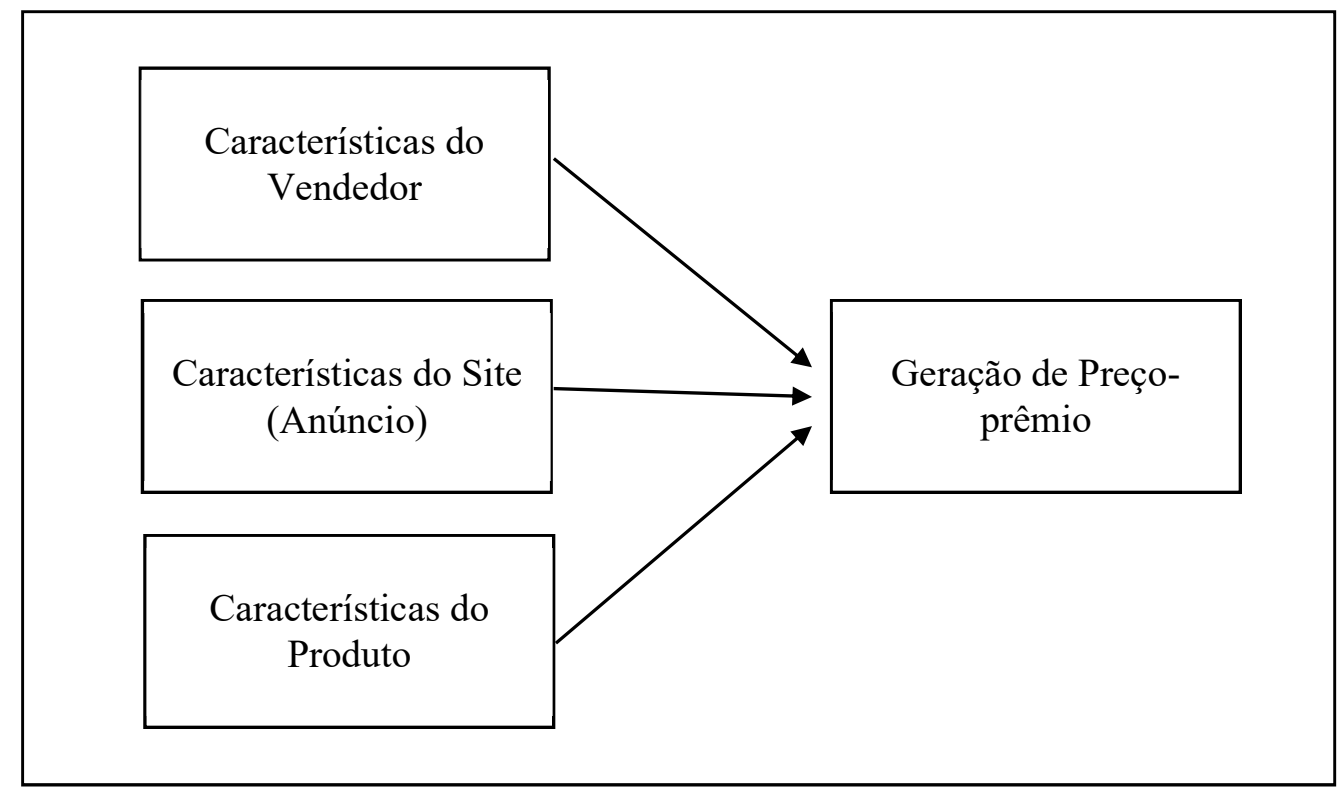

Fonte: Elaborado pelo autor. 
Esta divisão das categorias segue a mesma linha proposta por Anderson et al (2004) em seu estudo sobre a influência do recurso buy it now nos leilões do site americano eBay. Para os autores, as características do produto e do vendedor são exógenas e influenciam a escolha do vendedor na estrutura do leilão. Estas escolhas, em conjunto com as preferências dos compradores, resultam no sucesso (ou não) do anúncio.

A Tabela 3 expande cada característica influenciadora do sucesso do anúncio, relacionando os fatores que serão considerados nesta pesquisa e o referencial teórico que o suporta. As características são descritas em maior detalhe nos próximos itens, bem como são apresentadas as hipóteses deste trabalho.

Tabela 3 - Fatores influenciadores do sucesso de um anúncio em um e-marketplace

\begin{tabular}{|c|c|c|c|}
\hline Característica & Fator & Definição & Autores que suportam \\
\hline \multirow{3}{*}{$\begin{array}{l}\text { Características } \\
\text { do vendedor }\end{array}$} & Reputação & $\begin{array}{l}\text { Histórico de transações } \\
\text { e seu respectivo sucesso } \\
\text { ou fracasso. }\end{array}$ & $\begin{array}{l}\text { (BA e PAVLOU, 2002; } \\
\text { BRUCE, HARUVY e RAO, } \\
\text { 2004; DELLAROCAS, } \\
\text { 2003; HOUSER } \\
\text { WOODERS, } \\
\text { RESNICK, ZECKHAUSER, } \\
\text { et al., 2006) }\end{array}$ \\
\hline & $\begin{array}{l}\text { Porte do } \\
\text { vendedor }\end{array}$ & $\begin{array}{l}\text { Tamanho percebido do } \\
\text { vendedor dentro da } \\
\text { plataforma. }\end{array}$ & $\begin{array}{l}\text { (ANDERSON, } \\
\text { FRIEDMAN, et al., 2007; } \\
\text { BLAND, BLACK e } \\
\text { LAWRIM, 2005) }\end{array}$ \\
\hline & Localização & $\begin{array}{l}\text { Em qual região do } \\
\text { Brasil está localizado o } \\
\text { vendedor (a partir de } \\
\text { onde será feito o envio } \\
\text { do produto) }\end{array}$ & Proposta por este trabalho. \\
\hline $\begin{array}{l}\text { Características } \\
\text { do anúncio }\end{array}$ & $\begin{array}{l}\text { Recursos } \\
\text { Multimídia }\end{array}$ & $\begin{array}{l}\text { Utilização de vídeo, } \\
\text { fotos e outros recursos. }\end{array}$ & $\begin{array}{l}\text { (ANDERSON, } \\
\text { FRIEDMAN, et al., 2004; } \\
\text { ANDERSON, FRIEDMAN, }\end{array}$ \\
\hline
\end{tabular}




\begin{tabular}{|c|c|c|c|}
\hline & & & $\begin{array}{l}\text { et al., 2007; BENTE, } \\
\text { BAPTIST e LEUSCHNER, } \\
\text { 2012;LI, SRINIVASAN e } \\
\text { SUN, 2009) }\end{array}$ \\
\hline & Divulgação & $\begin{array}{l}\text { Destaque para o } \\
\text { anúncio contratado na } \\
\text { plataforma }\end{array}$ & $\begin{array}{l}\text { (ANDERSON, } \\
\text { FRIEDMAN, et al., 2004) }\end{array}$ \\
\hline & $\begin{array}{l}\text { Pagamento e } \\
\text { Entrega }\end{array}$ & $\begin{array}{l}\text { Formas de pagamento } \\
\text { aceitas e serviços de } \\
\text { escrow (ex: } \\
\text { MercadoPago) }\end{array}$ & $\begin{array}{l}\text { (LI, SRINIVASAN e SUN, } \\
\text { 2009; ZHANG e LI, 2006) }\end{array}$ \\
\hline & Serviço & $\begin{array}{l}\text { Informações sobre } \\
\text { garantia e pós-venda }\end{array}$ & $\begin{array}{l}\text { (DEWALLY } \\
\text { EDERINGTON, } \\
\text { GREGG e WALCZAK, } \\
2008)\end{array}$ \\
\hline & Histórico & $\begin{array}{l}\text { Realização de vendas } \\
\text { anteriores por um } \\
\text { anúncio e quantidade de } \\
\text { dias que ele ficou } \\
\text { exposto. }\end{array}$ & Proposta por este trabalho. \\
\hline \multirow[t]{2}{*}{$\begin{array}{l}\text { Características } \\
\text { do produto }\end{array}$} & Estado & Produto novo ou usado & $\begin{array}{l}\text { (ANDERSON, } \\
\text { FRIEDMAN, et al., 2004; } \\
\text { GREGG e WALCZAK, } \\
2008)\end{array}$ \\
\hline & Tipo & $\begin{array}{l}\text { Produto homogêneo ou } \\
\text { específico }\end{array}$ & (MELNIK e ALM, 2005) \\
\hline
\end{tabular}

Fonte: Elaborado pelo autor.

\subsubsection{Características do vendedor}

Em um EM como o Mercado Livre podem existir dezenas, ou até centenas, de vendedores diferentes anunciando um mesmo produto ao mesmo tempo. Os clientes não possuem informações completas sobre as ações do vendedor ou estado do produto, gerando um problema de assimetria de informação, que pode resultar em comportamentos oportunistas. No caso dos EMs, estes comportamentos podem ser atrasos injustificáveis na entrega, produtos que não 
correspondem exatamente ao que foi descrito, ao não envio do produto após recebimento do pagamento entre outros. (BA e PAVLOU, 2002)

Em um mercado com estas características, um comprador não tem como saber se o vendedor é confiável, ou seja, se cumprirá com suas promessas, ou se aproveitará a oportunidade para trapacear e maximizar seus lucros. Os EMs estabelecem mecanismos para facilitar a identificação dos vendedores honestos. A partir destes mecanismos, como o histórico de transações realizadas pelo vendedor e a construção de sua reputação, os compradores conseguem identificar aqueles que consideram mais confiáveis. Estes vendedores, classificados como confiáveis, conseguem melhores resultados que aqueles com má reputação ou com reputação desconhecida. (DELLAROCAS, 2003)

A partir do exposto, estabelece-se as três primeiras hipóteses deste trabalho:

\section{H1 - Vendedores com boa reputação influenciam positivamente a geração de preço prêmio.}

As avaliações do vendedor podem ser observadas em duas dimensões: os valores absolutos, que indicam um longo histórico de atividades no site, e os valores relativos de avaliações positivas ou negativas, que mostram um padrão do comportamento do vendedor. Além das avaliações do vendedor, os compradores também podem ser influenciados pela quantidade de vendas realizadas por eles. Um vendedor que possui um maior volume de vendas pode parecer mais estável e atrair mais compradores.

As plataformas de e-marketplace com sucesso no mercado oferecem em geral recursos específicos para sinalizar a reputação dos vendedores aos compradores. No Mercado Livre a quantidade exata de avaliações positivas e negativas, apesar de estarem disponíveis na página de perfil de usuário do vendedor, não é exibida no anúncio.

Mas em todos os anúncios há uma seção de "Reputação como vendedor" na qual é exibido o histórico como vendedor do usuário que está ofertando o produto. Nesta seção, uma faixa variando de vermelho a verde, conhecida como "termômetro", indica o nível do vendedor. Novos vendedores não possuem qualquer indicação de cor e os compradores enxergam o texto "vendedor novo" ao invés da escala de cores. A partir da décima negociação realizada na 
plataforma, o termômetro entra em vigor. A Figura 5 mostra este termômetro é exibido no anúncio.

Figura 5 - Seção de reputação em um anúncio

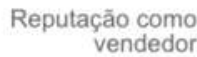
vendedor

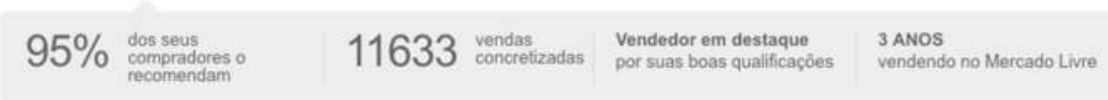

Ver mais dados deste vendedor

Fonte: Mercado Livre

O Mercado Livre não divulga o cálculo efetuado para qualificar os usuários entres estes cinco níveis, mas informa as variáveis que leva em consideração. A cor atribuída ao vendedor é determinada a partir da quantidade e o valor das vendas realizadas, a avaliação dos compradores, a modalidade de entrega utilizada (vendedores que utilizam o MercadoEnvios recebem melhor colocação no termômetro) e o tipo de anúncio (vendedores que pagam para que seus anúncios recebam maior exibição também recebem melhor colocação).

Neste trabalho a reputação do vendedor será medida de acordo com as variáveis descritas na Tabela 4.

Tabela 4 - Variáveis relacionadas à reputação

\begin{tabular}{|l|l|l|}
\hline Macro variável & Variável & Definição \\
\hline \multirow{2}{*}{ Reputação } & TERMOMETRO & $\begin{array}{l}\text { Classificação do vendedor } \\
\text { na plataforma. Um } \\
\text { vendedor pode ser } \\
\text { classificado como novo, } \\
\text { vermelho (pior), laranja, } \\
\text { amarelo, verde claro ou } \\
\text { verde escuro (melhor). }\end{array}$ \\
\cline { 2 - 4 } & \multirow{2}{*}{ PERCENTNEGATIVO } & $\begin{array}{l}\text { Percentual das vendas } \\
\text { realizadas que foram } \\
\text { avaliadas negativamente } \\
\text { pelo comprador. }\end{array}$ \\
& &
\end{tabular}




\begin{tabular}{|l|l|l|}
\hline & IDADEVENDEDOR & $\begin{array}{l}\text { Tempo (em dias) que o } \\
\text { vendedor possui conta no } \\
\text { Mercado Livre }\end{array}$ \\
\hline
\end{tabular}

Fonte: Elaborado pelo autor

\section{H2 - Grandes vendedores influenciam positivamente a geração de preço prêmio}

Em um e-marketplace como o Mercado Livre grandes lojas estão concorrendo com pequenos vendedores. Usuários com muitas vendas podem enviar seus documentos para o Mercado Livre para serem classificados como um MercadoLíder. Estes vendedores recebem um selo que sinaliza seu porte aos compradores em três categorias: MercadoLíder, MercadoLíder Gold ou MercadoLíder Platinum.

Figura 6 - Seção de reputação em um anúncio de vendedor MercadoLíder Gold

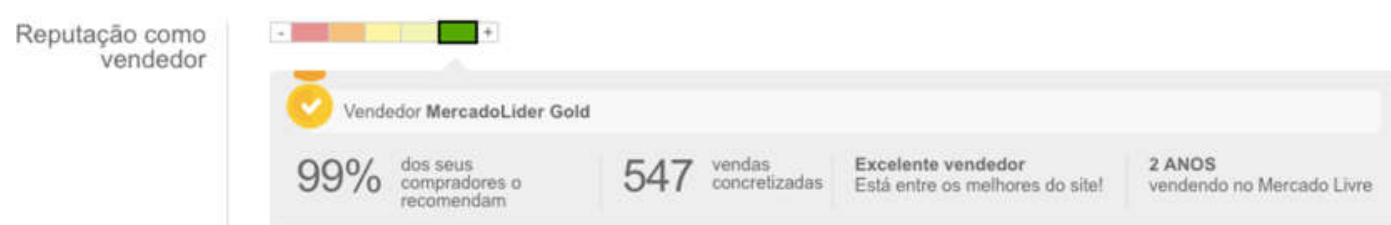

Fonte: Mercado Livre

Para se tornar um MercadoLíder, além do volume de vendas, é necessário possuir um cadastro com mais de quatro meses, ter o termômetro na cor verde, menos que 5\% das vendas com reclamações que necessitaram de mediação do Mercado Livre, não possuir débitos com o Mercado Livre e apresentar documentação e comprovação fiscal. A categorização entre o nível inicial, Gold ou Platinum é baseada exclusivamente no volume de vendas dos últimos três meses e segue, respectivamente, os seguintes critérios: 60 vendas ou mais e faturamento superior a $\mathrm{R} \$ 36.500,150$ vendas ou mais e faturamento superior a $\mathrm{R} \$ 150.000$ e 450 vendas ou mais e faturamento superior a $\mathrm{R} \$ 320.000$.

Além da medalha, os anúncios dos vendedores MercadoLider recebem maior destaque e os vendedores um atendimento diferenciado (incluindo suporte por on-line por chat e palestras de capacitação). 
Grandes lojas, como Extra ou Ricardo Eletro, também podem realizar vendas pela plataforma do Mercado Livre. Estas lojas também recebem uma indicação especial. A Figura 7 apresenta como o selo de "loja oficial” é exibido no anúncio.

Figura 7 - Selo de loja oficial que é exibido no topo do anúncio do produto

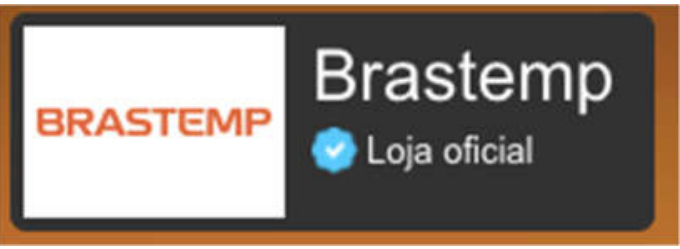

Fonte: Mercado Livre.

Neste trabalho, incialmente, o porte de um vendedor seria considerado de acordo com a quantidade de vendas, os selos de MercadoLíder e o selo de loja oficial. No entanto, o número de vendas realizado por lojas oficiais nas categorias analisadas neste trabalho é mínimo e por isso esta variável foi desconsiderada. Dessa forma, o porte do vendedor é mensurado pelas seguintes variáveis:

Tabela 5 - Variáveis relacionadas ao porte do vendedor

\begin{tabular}{|l|l|l|}
\hline Macro variável & Variável & Definição \\
\hline & & Classificação do \\
Porte do vendedor & vendedor como \\
& MERCADOLIDER & MercadoLider. Um \\
& vendedor pode ser \\
& classificado como não- \\
& MercadoLider, \\
& MercadoLider Silver, \\
& MercadoLider Gold ou \\
& MercadoLider Platinum. \\
\hline
\end{tabular}




\begin{tabular}{|l|l|l|}
\cline { 3 - 3 } & \multicolumn{1}{|l|}{$\begin{array}{l}\text { Quantidade de vendas } \\
\text { realizadas na plataforma } \\
\text { em toda a história do } \\
\text { Tendedor. Não são }\end{array}$} \\
& $\begin{array}{l}\text { TRANSACOESCOMPLETAS } \\
\text { incluídas as vendas } \\
\text { iniciadas mas canceladas } \\
\text { (por exemplo, por falta } \\
\text { de pagamento). }\end{array}$ \\
\hline
\end{tabular}

Fonte: Elaborado pelo autor

H3 - Vendedores em grandes centros praticam preços diferentes dos vendedores em interiores

A localização física do vendedor pode influenciar o seus custos operacionais, a facilidade de obtenção do produto, os custos de envio para o comprador (sejam eles pagos pelo vendedor ou pelo comprador), sua percepção de preço praticado pelos concorrentes físicos e a percepção do usuário comprador. Todos estes fatores podem influenciar no preço praticado pelo vendedor.

A cidade do vendedor é exibida como filtro no resultado das buscas e também dentro do anúncio, em destaque, próximo aos dados do vendedor.

Tabela 6 - Variáveis relacionadas a localização do vendedor

\begin{tabular}{|l|l|l|}
\hline Macro variável & Variável & Definição \\
\hline $\begin{array}{l}\text { Localização do } \\
\text { Vendedor }\end{array}$ & NACAPITAL & $\begin{array}{l}\text { O vendedor está } \\
\text { localizado em uma } \\
\text { cidade que é capital ou } \\
\text { não. }\end{array}$ \\
\hline
\end{tabular}

Fonte: Elaborado pelo autor.

\subsubsection{Características do anúncio}

Uma das atividades-chave para os vendedores nos e-marketplaces é conseguir reduzir a assimetria de informação melhor que seus concorrentes, mostrando-se mais atrativo para os consumidores. Entre as estratégias possíveis para isso estão a sinalização através do oferecimento de garantias, aparência do website e reputação. (LI, FANG, et al., 2015) 
As quatro hipóteses a seguir estão relacionadas as características do anúncio:

H4 - Anúncios com recursos multimídia (fotos e vídeos) influenciam positivamente a geração de preço prêmio.

O Mercado Livre permite que cada anúncio contenha até seis fotos e um vídeo. Uma das fotos é exibida em destaque, em miniatura, ao lado do anúncio na listagem do resultado das buscas. As outras cinco fotos, se existentes, são exibidas apenas na página do anúncio, em miniaturas até que o usuário comprador as acesse (Figura 8). O vídeo é sempre inserido no final da lista de fotos.

Figura 8 - Anúncio com quatro fotos e um vídeo

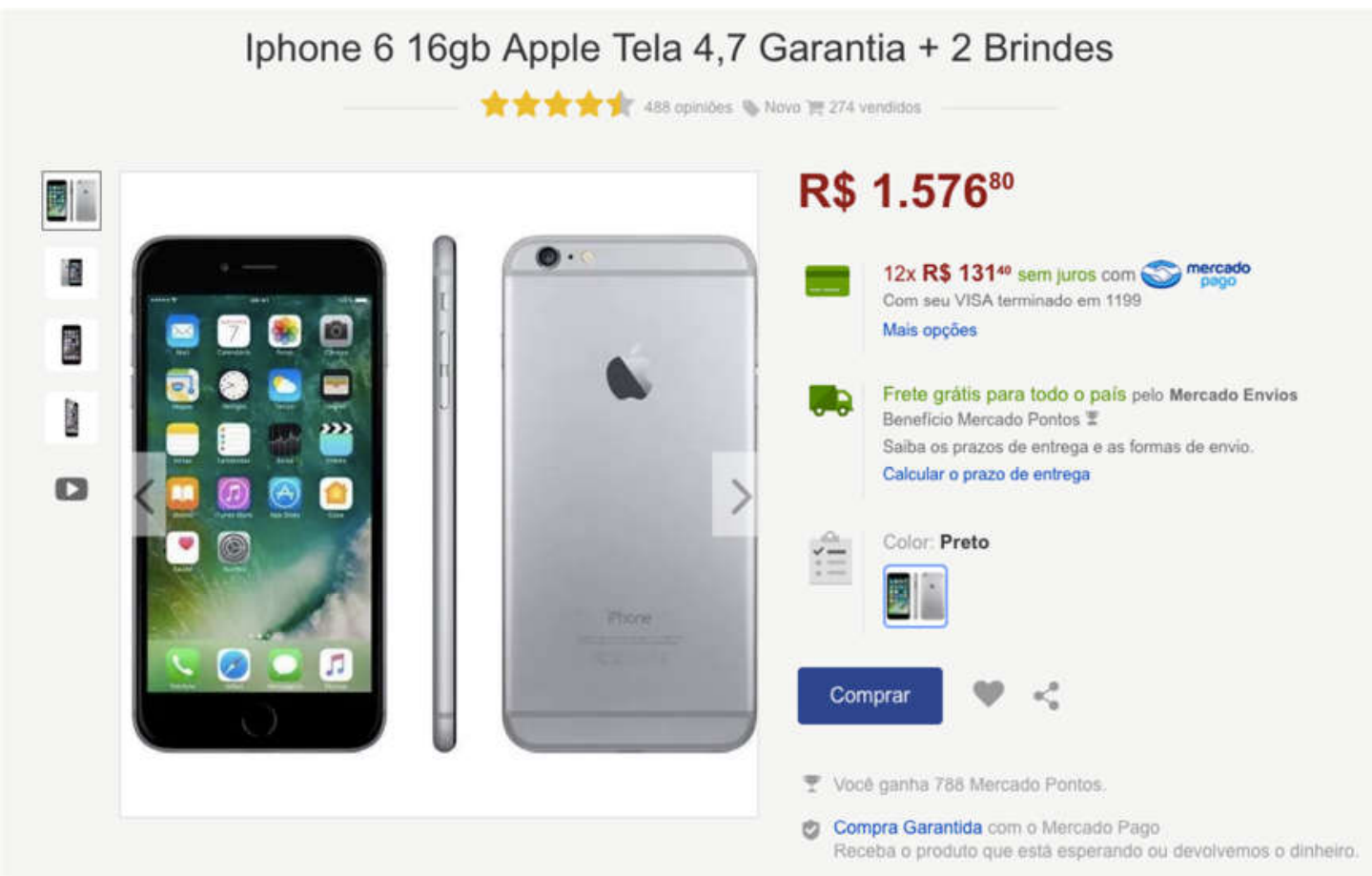

Fonte: Mercado Livre.

A Tabela 7 mostra as variáveis consideradas para representar a presença de recursos multimídia no anúncio. 
Tabela 7 - Variáveis relacionadas ao uso de recursos multimídia

\begin{tabular}{|l|l|l|}
\hline Macro variável & Variável & Definição \\
\hline \multirow{3}{*}{ Recursos Multimídia } & QTDFOTOS & $\begin{array}{l}\text { Número de fotos } \\
\text { disponibilizadas no } \\
\text { anúncio. }\end{array}$ \\
\cline { 2 - 3 } & VIDEO & $\begin{array}{l}\text { Presença de vídeo no } \\
\text { anúncio. }\end{array}$ \\
\hline
\end{tabular}

Fonte: Elaborado pelo autor.

\section{H5 - Anúncios que apresentam um bom serviço influenciam positivamente a geração de preço prêmio.}

O Mercado Livre, e demais plataformas neste formato, principalmente em seus primeiros anos, foi palco de várias negociações informais, sem garantias ou nota fiscal, ocorrendo principalmente entre pessoas físicas. O próprio nome do website e seu slogan ("onde você compra e vende de tudo") ressalta esta característica de livre mercado, onde é fácil realizar vendas sem burocracias e formalidades.

Mas o alto volume proporcionado por estas ferramentas atraiu vendedores profissionais, ou contribuiu para a profissionalização de alguns vendedores. Com isto, surgiram anúncios que deixam evidente em que enviam a nota fiscal junto com o produto e os detalhes de garantia do produto. Em relação à este último ponto, todos os anúncios pagos pelo MercadoPago possuem garantia de devolução do dinheiro pelo Mercado Livre caso não haja entrega ou ela esteja em desacordo com o que foi anunciado. A garantia adicional oferecida pelos vendedores, caso desejem, é informada em um campo adicional, que é exibido na página do anúncio (Figura 9).

Figura 9 - Seção de garantia do anúncio, com garantia adicional do vendedor de 90 dias

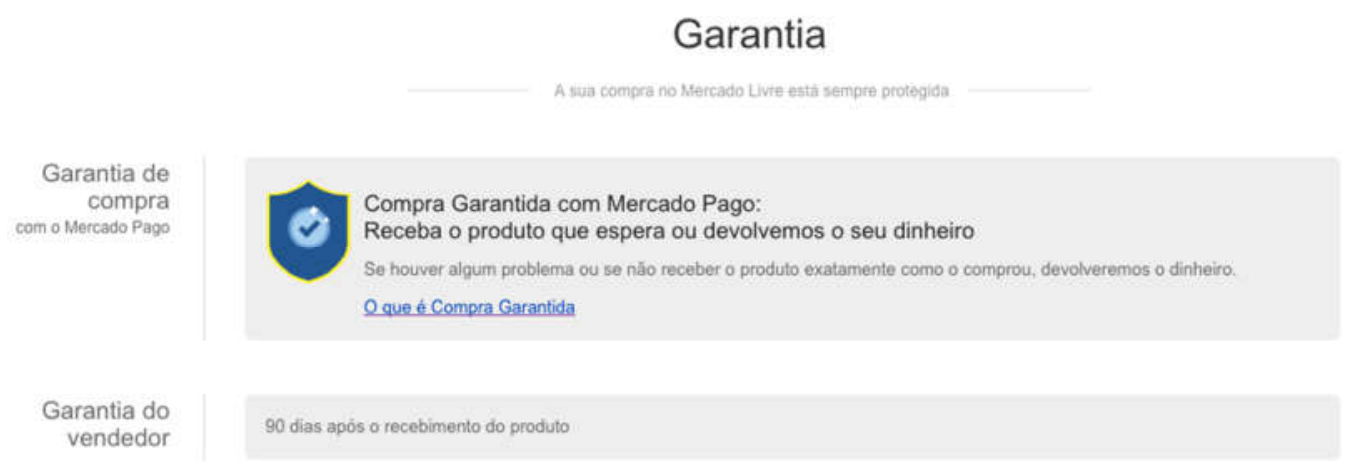

Fonte: Mercado Livre. 
Neste trabalho, a macro variável serviço é composta das variáveis de emissão de nota fiscal e garantia do vendedor (Tabela 8).

Tabela 8 - Variáveis relacionadas ao serviço

\begin{tabular}{|l|l|l|}
\hline Macro variável & Variável & Definição \\
\hline \multirow{2}{*}{ Serviço } & EMITENF & $\begin{array}{l}\text { Indica se o vendedor } \\
\text { explicitamente afirma emitir } \\
\text { nota fiscal no texto de } \\
\text { descrição do anúncio. Valores } \\
\text { possíveis são: não menciona, } \\
\text { emite ou não emite. }\end{array}$ \\
\cline { 2 - 3 } & GARANTIA & $\begin{array}{l}\text { Indica se o vendedor } \\
\text { explicitamente comenta no } \\
\text { anúncio sobre garantia. }\end{array}$ \\
\hline
\end{tabular}

Fonte: Elaborado pelo autor.

\section{H6 - Anúncios que com frete gratuito influenciam positivamente a geração de preço prêmio.}

Os vendedores do Mercado Livre podem utilizar os serviços do MercadoEnvios para entregar o produto ao comprador. Com este serviço, o usuário comprador consegue calcular e pagar o frete em tempo real no momento da compra e o usuário vendedor precisa apenas imprimir uma etiqueta para postar nos correios. Sem este recurso, o comprador precisa fazer uma pergunta ao vendedor para saber o valor do frete. Este recurso, apesar de opcional, é adotado por quase todos os vendedores da plataforma e por isso não foi considerado.

O custo do frete pode ser pago pelo comprador ou pelo vendedor. Caso o frete seja gratuito para o comprador, esta informação é exposta em destaque entre os resultados da busca. Na Figura 10, o resultado de uma busca mostra dois anúncios. No primeiro, o comprador é responsável pelos custos do frete e no segundo o vendedor arca com esta despesa. O vendedor pode ainda selecionar que permite que retirem o produto em mãos. Neste caso, não há maior exposição e esta informação é exibida apenas na página de cálculo do frete. 
Figura 10 - Resultado de busca com indicação sobre o frete Apple Iphone $616 \mathrm{gb}$ Tela 4,7 Novo Desbloqueado Fabrica

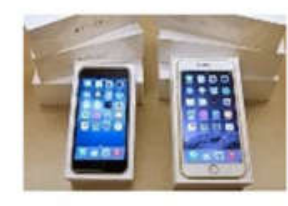
$\mathrm{R} \$ 1.850$

$12 \times R \$ 154$ sem juros

Envios para todo o pais

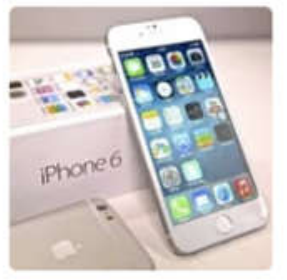

Iphone $616 \mathrm{gb}$

$\mathrm{R} \$ 1.649$

$12 \times$ R\$ 137 sem juros

Frete grátis para todo o pais

Fonte: Mercado Livre.

Levou-se em consideração neste trabalho, em relação ao frete, se o vendedor oferece frete gratuito (Tabela 9).

Tabela 9 - Variáveis relacionadas ao pagamento e a entrega

\begin{tabular}{|l|l|l|}
\hline Macro variável & Variável & Definição \\
\hline FRETE & FRETEGRATIS & $\begin{array}{l}\text { Indica se o vendedor } \\
\text { arca com os custos de } \\
\text { envio do produto. }\end{array}$ \\
\hline
\end{tabular}

Fonte: Elaborado pelo autor.

\section{H7 - A maior exposição de um anúncio influencia positivamente a geração de preço prêmio.}

É intuitivo imaginar que um anúncio que receba mais visitas, mesmo com um preço maior que os demais, acabe aumentando suas chances de conseguir encontrar um comprador disposto a pagar o preço ofertado.

Não há custos para anunciar na modalidade mais simples do Mercado Livre. Mas o vendedor pode optar por pagar um percentual do valor de cada venda para que seu anúncio tenha maior destaque. Esta exposição adicional pode ocorre em dois níveis (denominados clássico e premium) e é determinante na ordem em que os resultados são exibidos quando um usuário 
efetua uma busca no site. Espera-se que um anúncio gratuito receba menos visitas que um pago no nível clássico e que este, por sua vez, receba menos visitas que um anúncio pago premium.

Não há indicação para um comprador se o anúncio é gratuito, clássico ou premium. Mas, ao efetuar a acessar um anúncio premium, o comprador enxerga a possibilidade de efetuar o pagamento da compra parceladamente em custos adicionais. Nas outras modalidades de anúncio, o parcelamento é oferecido mas há uma cobrança de juros.

A exposição do anúncio é composta pelo tipo do anúncio e pela quantidade de visitas recebida (Tabela 10)

Tabela 10 - Variáveis relacionadas à divulgação

\begin{tabular}{|l|l|l|}
\hline Macro variável & Variável & Definição \\
\hline \multirow{2}{*}{ Exposição } & TIPODOANUNCIO & $\begin{array}{l}\text { Indica se o vendedor tem } \\
\text { pagou por uma maior } \\
\text { exposição do anúncio (e } \\
\text { qual o tipo de exposição } \\
\text { adicional foi contratada: } \\
\text { clássica ou premium) }\end{array}$ \\
\hline
\end{tabular}

Fonte: Elaborado pelo autor

\section{H8 - O histórico do anúncio influencia positivamente a geração de preço prêmio.}

Um anúncio gratuito fica exposto no Mercado Livre por no máximo 60 dias ou até todas as unidades disponibilizadas terem sido vendias. Já um anúncio pago fica exposto por quanto tempo o vendedor desejar. Ele pode inclusive, pausar temporariamente o anúncio e habilitá-lo novamente no futuro, reaproveitando todo o conteúdo e o seu histórico (perguntas respondidas, quantidade de vendas realizadas etc). Também é possível, a qualquer momento, alterar o preço ofertado no anúncio.

A idade do anúncio, ou seja, quando ele foi publicado pela primeira vez, não fica disponível para o comprador. A quantidade de unidades vendidas é exposta na página do anúncio, logo abaixo do título 
Figura 11 - Exemplo de anúncio que resultou em 319 unidades vendidas

\section{Apple Iphone 6 16gb, Refurbished, Nfe, Novo, Garantia!}

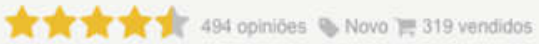

Fonte: Mercado Livre.

Um anúncio com muitas vendas pode passar maior credibilidade ao comprador. Um anúncio mais antigo pode significar que ele já foi validado pelo vendedor como um anúncio que traz bons resultados. Além disso, o histórico de perguntas e respostas do anúncio esclarece os possíveis questionamentos do comprador e reduz incertezas.

Tabela 11 - Variáveis relacionadas à divulgação

\begin{tabular}{|l|l|l|}
\hline Macro variável & Variável & Definição \\
\hline \multirow{3}{*}{ Histórico do Anúncio } & IDADEDOANÚNCIO & $\begin{array}{l}\text { Quantidade de dias } \\
\text { desde sua primeira } \\
\text { publicação até a venda. }\end{array}$ \\
\cline { 2 - 3 } & QTDVENDANUN & $\begin{array}{l}\text { Quantidade de unidades } \\
\text { vendidas pelo anúncio } \\
\text { desde sua publicação até } \\
\text { o início do dia em que a } \\
\text { venda foi realizada }\end{array}$ \\
\hline
\end{tabular}

Fonte: Elaborado pelo autor.

\subsubsection{Características do produto}

A intensidade da influência da reputação do vendedor e das demais características do anúncio na disposição para comprar e no valor pago não é a mesma para todos os produtos. Esta intensidade é maior nos produtos mais caros (DELLAROCAS, 2003) e em produtos heterogêneos, quando há maior incerteza sobre sua qualidade (MELNIK e ALM, 2003). A última hipótese proposta neste trabalho, apresentada a seguir, trata justamente desta diferença de acordo com o produto. 


\section{H9 - As influências das características do vendedor e do anúncio apresentam diferente magnitude de acordo com o produto anunciado.}

Na definição de Melnik e Alm (2003), um produto é considerado homogêneo quando o comprador já sabe exatamente o que espera receber ao efetuar a compra. Não existem muitas variações possíveis do produto, e ele não sente a necessidade de explorar o produto antes da compra. Neste trabalho, utilizamos como exemplo de um produto homogêneo o Iphone 6 de $16 \mathrm{gb}$ novo. Além das variações de cor, não são esperadas outras diferenças entre duas unidades do produto.

Um produto heterogêneo é aquele cujos detalhes precisam ser explicados ou demonstrados para que possam ser entendidos. Um possível exemplo é a venda de trabalhos feitos à mão, como uma escultura. Cada escultura, mesmo que do mesmo artista e com o mesmo tema, possui infinitas diferenças em relação as demais. Neste trabalho, adotamos como produto heterogêneo os modelos de tênis femininos do fabricante Osklen. A faixa de preço das diversas variações destes tênis não possuem diferença significativa. Vários vendedores, inclusive, expõem diversos modelos em um mesmo anúncio. Mas, para que o consumidor consiga entender exatamente o produto, é preciso um bom detalhamento de suas especificações.

Considerou-se aqui também alguns produtos intermediários. Por exemplo, um Iphone $616 \mathrm{gb}$ usado ganha características heterogêneas (há riscos? está na caixa?). Um Playstation 4 também, mesmo novo, não é um produto completamente homogêneo. Existem pequenas variações do produto que precisam ser explicadas (quantidade de controles, capacidade de armazenamento, inclusão ou não de jogos, edições especiais etc).

No total, neste trabalho são considerados três produtos: iPhone 6, Playstation 4 e tênis Osklen feminino. Os dois primeiros possuem tanto itens novos quanto usados. Já para os tênis foram considerados apenas os anúncios de itens novos (Tabela 12). 
Tabela 12 - Produtos considerados

\begin{tabular}{|c|c|c|c|}
\hline Produto & Estado & $\begin{array}{ll}\text { Homogêneo } & \text { ou } \\
\text { heterogêneo } & \end{array}$ & Nível de preço \\
\hline Iphone 6 16gb & Novo & $\begin{array}{l}\text { Bastante } \\
\text { Homogêneo }\end{array}$ & Alto \\
\hline Iphone 6 16gb & Usado & $\begin{array}{l}\text { Intermediário } \\
\text { tendendo para } \\
\text { heterogêneo }\end{array}$ & Alto \\
\hline Playstation 4 & Novo & $\begin{array}{l}\text { Intermediário } \\
\text { tendendo para } \\
\text { homogêneo }\end{array}$ & Alto \\
\hline Playstation 4 & Usado & Heterogêneo & Alto \\
\hline $\begin{array}{ll}\text { Tenis } & \text { Osklen } \\
\text { Feminino } & \end{array}$ & Novo & Heterogêneo & Baixo \\
\hline
\end{tabular}

Fonte: Elaborado pelo autor.

No modelo também foram consideradas as variáveis ESTADODOITEM (novo ou usado) e NACAIXA ( 1 - sim ou 0 - não) para indicar os casos onde o vendedor explicitamente informou no título ou na descrição que o produto seria enviado na caixa original. 


\section{METODOLOGIA}

Em relação ao seu objetivo, esta é uma pesquisa descritiva e exploratória. Segundo Gil (2008, p. 28), este tipo de estudo tem “...como objetivo primordial a descrição das características de determinada população ou fenômeno ou o estabelecimento de relações entre variáveis". O autor destaca que algumas pesquisas descritivas se aproximam das explicativas, como acontece neste trabalho. Neste caso, vai-se além da simples identificação da relação, buscando-se explorar e entender a natureza dessa relação.

Quanto a forma de abordagem, trata-se de uma pesquisa quantitativa. Esta abordagem, como o próprio nome sugere, envolve a análise de quantidades. Para isso, a pesquisa quantitativa “considera que tudo pode ser quantificável, o que significa traduzir em números opiniões e informações para classificá-las e analisá-las" (SILVA e MENEZES, 2005, p. 20). Por utilizar dados numéricos, a análise é facilitada pelo uso da matemática e dos métodos estatísticos. Estes instrumentos "permitem reduzir uma grande massa de informações a alguns indicadores, que são capazes de representar as principais características do objeto analisado" (CERVI, 2009, p. 135)

Para Ramos (2013), pesquisas quantitativas são adequadas para tratar questões que envolvem relações causais, por meio das quais testamos hipóteses e tentamos entender se as variáveis em análise (independentes e dependentes) andam juntas e qual o sentido e a força da relação entre elas. Cervi (2009) destaca que geralmente as pesquisas quantitativas possuem uma perspectiva empírica, buscando a descrição mais detalhada possível da realidade através de dados primários (levantados para a realização da pesquisa) ou secundários (já existentes e aproveitados na pesquisa). Esses dados são usados "em análises que permitem generalizações, indicação de relações de causalidade e, como consequência, para a validação ou rejeição de teorias" (CERVI, 2009, p. 128)

Este trabalho foi realizado em três etapas. A primeira delas foi uma revisão sistemática da literatura, buscando compreender o que já foi pesquisado sobre o tema e construir um arcabouço teórico sob o qual será realizado o trabalho. A etapa seguinte foi a coleta dos dados reais do Mercado Livre. Houve o desenvolvimento de um programa para captura dos dados que utilizará a API disponibilizados pelo próprio Mercado Livre e também o download das páginas dos anúncios para identificar as variáveis de interesse que não são disponibilizadas pelos 
webservices do Mercado Livre. Acontece ainda uma revisão e classificação manual dos dados coletados. Finalmente, ocorreu uma etapa de análise e discussão dos resultados, onde são aplicadas técnicas estatísticas para encontrar relações entre as variáveis e propor um modelo.

\subsection{API do Mercado Livre}

Antes da descrição de como se da a coleta de dados, faz sentido uma explicação do conceito de Application Programming Interface (API). Uma API é uma definição de padrões, comandos e formatos de mensagens, que permite que dois softwares interajam entre si.

Um caso particular, chamado de Web API, ocorre quando esta é feita para possibilitar que os sistemas interajam através da Internet. O fornecedor da API disponibiliza uma documentação com os comandos que podem ser enviados por Hyper Text Transfer Protocol (HTTP) e o formato em que será disponibilizada a resposta (geralmente um arquivo com as informações em formato Extended Markup Language - XML ou em JavaScript Object Notation - JSON).

Um exemplo de aplicação destas APIs são os softwares de gestão de lojas virtuais, como os desenvolvidos por empresas tais como o $\mathrm{VTEX}^{3}$, Tray ${ }^{4} \mathrm{e}^{\mathrm{Plugg}}{ }^{5}$. Através deles, o vendedor elabora o anúncio uma única vez em um programa e as informações são enviadas para diversas plataformas (ex.: Mercado Livre, Submarino Marketplace e site do próprio vendedor) através de suas respectivas APIs. Quando ocorre uma venda, independentemente do site em que ela foi concretizada, o pedido é encaminhado de volta, novamente utilizando a API, para um fluxo único definido pelo programa.

Praticamente todos os grandes EMs brasileiros, incluindo a B2W (Submarino, Americanas e Shoptime) e a CNOVA (Ponto Frio, Extra e Casas Bahia), disponibilizam uma API. No entanto, na maioria dos casos, o escopo da API está limitado às funções de gestão dos próprios anúncios do vendedor no e-marketplace da loja.

A API disponibilizada pelo Mercado Livre, no entanto, possui escopo mais amplo. Além da criação de anúncios, ela permite a realização de buscas, acesso a dados públicos sobre os

\footnotetext{
${ }^{3} \mathrm{http}: / /$ pt.vtex.com

${ }^{4}$ http://www.tray.com.br

${ }^{5}$ http://plugg.to
} 
usuários do site, acesso a dados públicos dos anúncios (ex: preço, descrição) entre outros. Com algumas poucas exceções, as principais funcionalidades existentes na versão convencional do site, acessada pelo navegador, também estão disponíveis através da sua API.

Este trabalho utilizou a API do Mercado Livre como principal ferramenta para a realização da coleta de dados. Esta API é única para todos os países em que o Mercado Livre/MercadoLibre possui operação. Ou seja, com um mesmo comando, alternando apenas um parâmetro, é possível, por exemplo, consultar dados de anúncios no Brasil (www.Mercado Livre.com.br) ou na Argentina (www.mercadolibre.com.ar) ou México (www.mercadolibre.com.mx). Este trabalho limitou a consulta para os registros da versão brasileira da plataforma.

A API do Mercado Livre está organizada, de acordo com sua documentação, em oito resources (MERCADO LIVRE, 2016). Apresenta-se a seguir uma descrição de cada um. Uma relação consolidada dos dados que serão coletados neste trabalho, incluindo aqueles que a princípio não serão utilizados, será apresentada mais adiante.

- Usuários e Aplicativos: Informações sobre o usuário e sobre o registro da aplicação que está executando a API. Além de suas próprias informações privadas, é possível acessar informações públicas de outros usuários (ex: apelido utilizado, data de registro, cidade e estado, quantidade de vendas realizadas, selo de MercadoLíder etc). Em relação a reputação, é disponibilizado apenas um total de pontos (que inclui todas as avaliações recebidas como comprador e como vendedor de forma agregada) e um percentual de quantas avaliações foram positivas, negativas e neutras. Não é possível observar a partir da API, por exemplo, quantas qualificações foram recebidas pelo usuário como vendedor e quantas como comprador.

- Categorias: Listagem de categorias e subcategorias. Permite navegar pela hierarquia de categorias, desde o mais abrangente até o mais específico. Não lista os anúncios da categoria, apenas descreve a árvore de classificações. A busca dos itens por categoria está descrita no resource “itens'. O nível de profundidade da árvore de categorias pode variar de acordo com o produto. Em alguns casos, como no iPhone, ela é desce até um nível bastante específico. A categoria MLB181935 por exemplo, agrupa apenas os anúncios de iPhone 6 16gb na cor cinza espacial. Navegando pela árvore de categorias, neste caso, são cinco níveis, a partir do mais abrangente ("Celulares e Telefones" -> "Celulares e Smartphones" -> "iPhone" -> "iPhone 6" -> "iPhone 6 16gb" -> "iPhone 6 16gb Cinza Espacial”). 
- Localização e moedas: informações sobre CEPs, moedas e taxas de conversão, para vendas internacionais.

- Itens e busca: relação de anúncios que atendem a um critério ou detalhes sobre um anúncio específico. É possível informar para a API uma palavra-chave ou uma categoria e receber todos os anúncios atuais que estão nela. Na busca não é possível consultar anúncios já encerrados. No entanto, caso haja interesse, é possível acessar detalhes específicos de qualquer anúncio a partir de seu número de identificação. Entre estes detalhes estão: título, número de identificação do vendedor, número de identificação de loja oficial (quando aplicável), número de identificação da categoria, preço cobrado, quantidade inicial, quantidade vendida, quantidade em estoque, tipo do anúncio (leilão ou preço fixo), destaque do anúncio (o vendedor pode pagar para o anúncio ter maior destaque, são duas categorias de anúncios premium), data e hora de início e fím do anúncio, condição do item (novo ou usado), fotos, vídeo, descrição do anúncio (em HTML ou texto simples), métodos de pagamento aceitos (inclusive MercadoPago), tipo de frete (inclusive se oferece frete grátis, se aceita que retirem a compra pessoalmente e se utiliza MercadoEnvio), cidade e estado do vendedor, garantia (campo em texto, escrito pelo vendedor), data de criação e de última atualização do anúncio.

- Perguntas e respostas: Mostra as perguntas e respostas para um anúncio. Inclui o texto da pergunta e da resposta, e a data de criação da pergunta e da resposta.

- Pedidos: Informações sobre as vendas realizadas. O acesso é restrito ao vendedor e usuários por ele autorizados.

- Métricas: Informações complementares, quantitativas, sobre os anúncios e usuários, que nem sempre estão disponíveis pelo site convencional. É possível acessar a quantidade de visitas a um anúncio, quantidade de visitas a todos os anúncios somados de um vendedor, quantidade de vezes que um usuário clicou em "ver telefone" (aplicável apenas para anúncios de grande valor, como carros e imóveis) e quantidade de perguntas feitas para um vendedor.

- Frete: Informações sobre cálculo do frete, recebendo como parâmetros de entrada o código do item, cep de origem e destino ou código do vendedor. O vendedor pode também registrar os envios de suas vendas.

Todas as variáveis que serão utilizadas na análise tiveram seu valor atribuído diretamente através de chamadas da API ou realizando-se cálculos em cima dos valores extraídos por meio 
dela. Um programa desenvolvido em Java pelo autor efetuou as diversas chamadas necessárias e armazenou o resultado em um banco de dados.

\subsection{Coleta de Dados}

O Mercado Livre não disponibiliza exatamente as informações de interesse deste estudo, que são os detalhes de cada venda realizada. Mas a plataforma permite extrair dados que possibilitam estimar estas transações com boa precisão. É possível extrair, para cada anúncio existente na plataforma, diversas informações sobre sua situação naquele instante. Isto inclui detalhes como preço atual, quantidade vendidas até aquele momento, informações sobre a reputação vendedor na hora da consulta entre outros.

\subsubsection{Estratégia de Coleta de Dados}

A primeira ideia para a coleta de dados das vendas realizadas na plataforma foi, então, realizar duas consultas de anúncios em momentos distintos e compará-las. A primeira consulta, no início do período, levantaria todos os anúncios disponíveis na plataforma e suas informações relacionadas (ex: quantidade de itens disponíveis). A segunda consulta, ao final do período, observaria os mesmos itens e o que aconteceu com eles.

Por exemplo, no dia 1, seria realizada uma busca por iPhones à venda no Mercado Livre, observando a existência de um anúncio com código MLB12345 oferecendo um telefone por $\mathrm{R} \$ 1000,00$ e que, até aquele momento, já havia realizado cinco vendas. Em um segundo momento no futuro, por exemplo, no dia 8 , uma nova consulta observaria que este mesmo anúncio com código MLB12345 apresentava 7 unidades vendidas até aquela data. A conclusão esperada, era que este anúncio havia gerado duas vendas de iPhones por $\mathrm{R} \$ 1000,00$ cada no prazo de uma semana.

Uma representação gráfica deste exemplo é apresentada na Figura 12. Observa-se que, a partir da comparação das duas coletas é gerado o extrato de vendas, com uma linha para cada transação que ocorreu no período. 
Figura 12 - Primeira abordagem proposta para a coleta de dados

Coleta do dia 1

\begin{tabular}{|c|c|c|c|c|}
\hline Id do Anúncio & MLB12345 & & & \\
\hline Preço & $\mathrm{R} \$ 1000,00$ & \multirow{3}{*}{\multicolumn{3}{|c|}{$\begin{array}{l}\text { Comparação entre a coleta do dia } 1 \\
\text { e a coleta do dia } 8(7-5=2 \text { vendas })\end{array}$}} \\
\hline Vendas até ad ata & 5 & & & \\
\hline Avaliações negativas & $0 \%$ & & & \\
\hline \multicolumn{2}{|l|}{ Coleta do dia 8} & & & \\
\hline Id do Anúncio & MLB12345 & \multirow{3}{*}{\multicolumn{3}{|c|}{$\begin{array}{l}\text { Banco de dados (extrato de vendas de } \\
\text { uma semana) }\end{array}$}} \\
\hline Preço & $\mathrm{R} \$ 1000,00$ & & & \\
\hline Vendas até a data & 7 & & & \\
\hline Avaliações negativas & $0 \%$ & \multirow{2}{*}{$\begin{array}{c}\text { Id do } \\
\text { Anúncio }\end{array}$} & \multirow[t]{2}{*}{ Preço } & \multirow{2}{*}{$\begin{array}{c}\text { Percentual } \\
\text { negativo } \\
\text { do } \\
\text { Vendedor }\end{array}$} \\
\hline & & & & \\
\hline & & MLB12345 & $\mathrm{R} \$ 1000,00$ & $0 \%$ \\
\hline & & MLB12345 & $\mathrm{R} \$ 1000,00$ & $0 \%$ \\
\hline
\end{tabular}

Fonte: Eleborado pelo autor.

Um programa inicial seguindo esta lógica chegou a ser elaborado, mas em uma análise mais criteriosa percebeu-se que esta abordagem possui dois problemas. O primeiro é que ela desconsidera todos os anúncios iniciados e finalizados entre as duas coletas. Ainda no exemplo, se um anúncio foi postado no dia 2 com apenas uma unidade e esta foi vendida no dia 3 , este anúncio não aparecerá em nenhuma das duas coletas (realizadas apenas no dia 1 e no dia 8). $\mathrm{O}$ segundo é que as variáveis podem sofrer alterações ao longo do tempo. O vendedor poderia, por exemplo, ter realizado uma venda por $\mathrm{R} \$ 1000,00$ no dia 1, recebido uma avaliação negativa, baixado o preço para $\mathrm{R} \$ 800,00$ no dia 2 e realizado a segunda venda por este valor no dia 3 . Apenas comparando os dias 1 e 8, todas essas variações seriam perdidas e não saberíamos os valores e as características reais de cada venda.

A estratégia foi então adaptada para contornar estes problemas. Ao invés de apenas comparar duas coletas, o programa foi desenvolvido para coletar os dados com maior frequência. Todos os dias, sempre no mesmo horário (1 da manhã para o iPhone, 3 da manhã para o PS4 e 5 da manhã para o tênis), o programa coletou todas as informações referentes aos anúncios destes produtos. Comparando um dia com o outro, agora sim, foi possível construir um extrato de vendas mais próximo da realidade. 
Figura 13 - Abordagem aperfeiçoada da coleta de dados

\section{Coleta no início do dia 1}

\begin{tabular}{|l|l|}
\hline Id do Anúncio & MLB12345 \\
\hline Preço & $\mathrm{R} \$ 1000,00$ \\
\hline Vendas até a data & 5 \\
\hline $\begin{array}{l}\text { Avaliações } \\
\text { negativas }\end{array}$ & $0 \%$ \\
\hline
\end{tabular}

Coleta no início do dia 2

\begin{tabular}{|l|l|}
\hline Id do Anúncio & MLB12345 \\
\hline Preço & $\mathrm{R} \$ 1000,00$ \\
\hline Vendas até a data & 6 \\
\hline $\begin{array}{l}\text { Avaliações } \\
\text { negativas }\end{array}$ & $0 \%$ \\
\hline
\end{tabular}

Coleta no início do dia 3

\begin{tabular}{|l|l|}
\hline Id do Anúncio & MLB12345 \\
\hline Preço & $\mathrm{R} \$ 800,00$ \\
\hline Vendas até a data & 6 \\
\hline $\begin{array}{l}\text { Avaliações } \\
\text { negativas }\end{array}$ & $5 \%$ \\
\hline
\end{tabular}

Coleta no início do dia 4

\begin{tabular}{|l|l|}
\hline Id do Anúncio & MLB12345 \\
\hline Preço & $\mathrm{R} \$ 800,00$ \\
\hline Vendas até a data & 7 \\
\hline $\begin{array}{l}\text { Avaliações } \\
\text { negativas }\end{array}$ & $5 \%$ \\
\hline
\end{tabular}

Banco de dados (extrato de vendas do período)

\begin{tabular}{|c|c|c|c|}
\hline $\begin{array}{c}\text { Dia } \\
\text { da } \\
\text { venda }\end{array}$ & $\begin{array}{c}\text { Id do } \\
\text { Anúncio }\end{array}$ & Preço & $\begin{array}{c}\text { Percentual } \\
\text { negativo } \\
\text { do } \\
\text { Vendedor }\end{array}$ \\
\hline Dia 1 & MLB12345 & $\mathrm{R} \$ 1000,00$ & $0 \%$ \\
\hline Dia 3 & MLB12345 & $\mathrm{R} \$ 800,00$ & $5 \%$ \\
\hline
\end{tabular}

Fonte: Elaborado pelo autor.

Esta abordagem ainda possui duas limitações: se mais de uma mudança ocorre no mesmo dia, não é possível saber qual ocorreu primeiro. Por exemplo, se um vendedor recebe várias avaliações ao longo do dia e seu anúncio realiza diversas vendas no mesmo dia, não sabe-se qual era a exata situação no momento de cada venda. Neste caso, está sendo adotado o valor das variáveis no começo do dia para todas as vendas realizadas naquele dia (exceto para a quantidade de vendas realizadas pelo anúncio e pelo vendedor até o momento da realização de cada venda, que é possível inferir logicamente e atribuir um valor sequencial). Outro caso não coberto por esta abordagem são vendas rápidas, quando um item é vendido no mesmo dia em 
que é anunciado, e não aparece em nenhuma das consultas. Entende-se que estas são limitações do trabalho e que não devem causar grandes impactos ao seu resultado.

A operacionalização deste processo de coleta segue, tecnicamente, uma metodologia inspirada em um processo de extract-transform-load (ETL) da construção de um data warehouse proposta por Inmon (2005) e ocorre em dois momentos. O primeiro momento é a coleta diária dos dados, automatizada através do desenvolvimento de um programa em Java que faz consultas às APIs do Mercado Livre e salva em um banco de dados MySQL. Seguindo a analogia, este momento equivale a realização da carga das tabelas que formam o data warehouse ${ }^{6}$. Este programa, após desenvolvido, fica salvo em um servidor e é executado automaticamente conforme agenda. $\mathrm{O}$ segundo momento ocorre com um outro script, desta vez puramente Structured Query Language (SQL), que é executado para gerar o extrato de vendas que serve como base deste estudo. Ainda seguindo o raciocínio de um ETL, o extrato de vendas seria o equivalente a o data mart $^{7}$. A Figura 14 mostra a este fluxo de coleta de dados.

Figura 14 - Fluxo de coleta de dados e geração do extrato de vendas

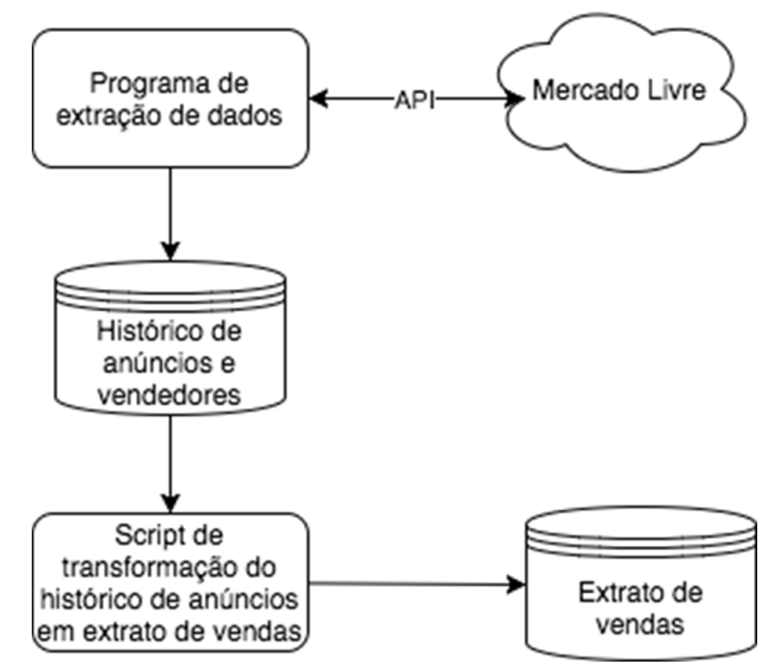

Fonte: Elaborado pelo autor.

\footnotetext{
${ }^{6}$ Um data warehouse é um depósito onde os dados coletados de outras fontes ou sistemas transacionais são armazenados para serem consultados futuramente.

${ }^{7}$ Data mart, de acordo com a proposta de arquitetura de Inmon (2005), é um conjunto de dados relacionados a determinado organizados para consulta a partir dos dados disponíveis no data warehouse.
} 


\subsubsection{Geração do histórico de anúncios e vendedores}

O programa de extração de dados, responsável por gerar as tabelas de histórico dos anúncios e vendedores com a situação de cada anúncio em cada dia de coleta, precisa conseguir realizar chamadas em sequência e seguir uma lógica para consolidar os dados de acordo com os contextos já que são realizadas diversas chamadas à API do Mercado Livre.

A primeira chamada tem como objetivo conseguir a lista de anúncios que estão ofertando os produtos desejados naquele momento. A resposta desta execução é exatamente o mesmo conteúdo que um usuário enxergaria ao buscar pelo item no site, inclusive com a quebra do resultado da busca em páginas. O programa realiza múltiplas chamadas até que todas as páginas tenham sido percorridas. São passados como parâmetro nestas chamadas os códigos identificadores das categorias de interesse: MLB169490, referente a iPhones 6 novos e usados; MLB118907, referente a consoles Playstation 4 novos e usados; e MLB185408, referente aos tênis femininos da marca Osklen, aplicando neste caso o filtro "produto novo". Desta forma, a URL utilizada nesta chamada, para acessar os anúncios de iPhone 6, por exemplo, que estejam

localizados na terceira página, considerando que cada página possui 100 anúncios é https://api.mercadolibre.com/sites/MLB/search?category=MLB169490\&limit=100\&offset=20 $\underline{0}$, onde category $=$ MLB169490 é a categoria, limit $=100$ informa que cada página deve possuir 100 anúncios e offset=200 que a listagem deve ocultar os 200 primeiros itens (primeiras duas páginas). O programa ajusta o valor do offset a cada chamada.

Esta execução permite ao programa salvar no banco de dados todos os anúncios (resource item, na terminologia adotada pela API do Mercado Livre) como eles encontram-se naquele momento. É importante ressaltar que esta chamada inicial, que busca anúncios no Mercado Livre, acessa apenas os anúncios ativos. Se um anúncio foi encerrado, seja por opção do vendedor ou porque todos os itens já foram vendidos, ele não é exibido em uma busca no site e, consequentemente, não é retornado na consulta. O programa, então, verifica no banco de dados quais anúncios estavam disponíveis no dia anterior e não estão no resultado da busca realizada no dia. Para cada anúncio faltante, o programa realiza uma consulta específica do item, passando como parâmetro o código identificador do anúncio, como, por exemplo, na URL https://api.mercadolibre.com/items/MLB743553563, em que MLB743553563 é o código identificador de um anúncio que estava no resultado da busca do dia anterior mas não apareceu como resultado da busca do dia. 
Esta abordagem permite salvar as principais informações do anúncio, exceto sua descrição. Esta informação é disponibilizada individualmente, sendo necessária mais uma chamada na API para cada anúncio.

No passo seguinte, é verificado no banco de dados quais são os vendedores responsáveis pelos anúncios relevantes naquele dia (incluindo os que foram finalizados no dia anterior) e, para cada vendedor, é feita uma chamada à API para o preenchimento dos seus dados como estão naquele instante. A figura 15 apresenta um Diagrama de Atividades com o fluxo detalhado do programa de extração de dados e as suas interações com a API do Mercado Livre e com o Banco de Dados.

O programa foi executado diariamente, sempre nos mesmos horários, durante 58 dias, desde 2/1/2017 até 1/3/2017. Após as execuções, foram construídas tabelas que mostram a situação de cada anúncio e vendedor, a cada dia. A Tabela 13 exemplifica o resultado desta etapa, com algumas das linhas e colunas salvas. A lista completa de todos os dados referentes ao anúncio que foram coletados encontra-se no Anexo A. o Anexo B os dados referentes os vendedores. Nos anexos estão inclusive os dados que foram coletados e acabaram não sendo utilizados na análise.

Tabela 13 - Exemplo da tabela de histórico do anúncio

\begin{tabular}{|l|l|l|l|l|l|l|}
\hline id & id_ad & etl_date & title & price & qty_sold & $\ldots$ \\
\hline 21668 & MLB820994585 & $02 / 01 / 2017$ & $\begin{array}{l}\text { Apple Iphone 6 16gb } \\
\text { 4g A1549 Na Caixa, } \\
\text { Pronta Entrega! }\end{array}$ & 1750,90 & 0 & $\ldots$ \\
\hline 39942 & MLB820994585 & $03 / 01 / 2017$ & $\begin{array}{l}\text { Apple Iphone 6 16gb } \\
\text { 4g A1549 Na Caixa, } \\
\text { Pronta Entrega! }\end{array}$ & 1750,90 & 2 & $\ldots$ \\
\hline 57714 & 'MLB820994585 & $04 / 01 / 2017$ & $\begin{array}{l}\text { Apple Iphone 6 16gb } \\
\text { 4g A1549 Na Caixa, } \\
\text { Pronta Entrega! }\end{array}$ & 1750,90 & 2 & \\
\hline$\ldots$ & $\ldots$ & $\ldots$ & $\ldots$ & $\ldots$ & $\ldots$ & \\
\hline
\end{tabular}

Fonte: Elaborado pelo autor. 
Figura 15 - Diagrama de Atividades do programa de extração de dados

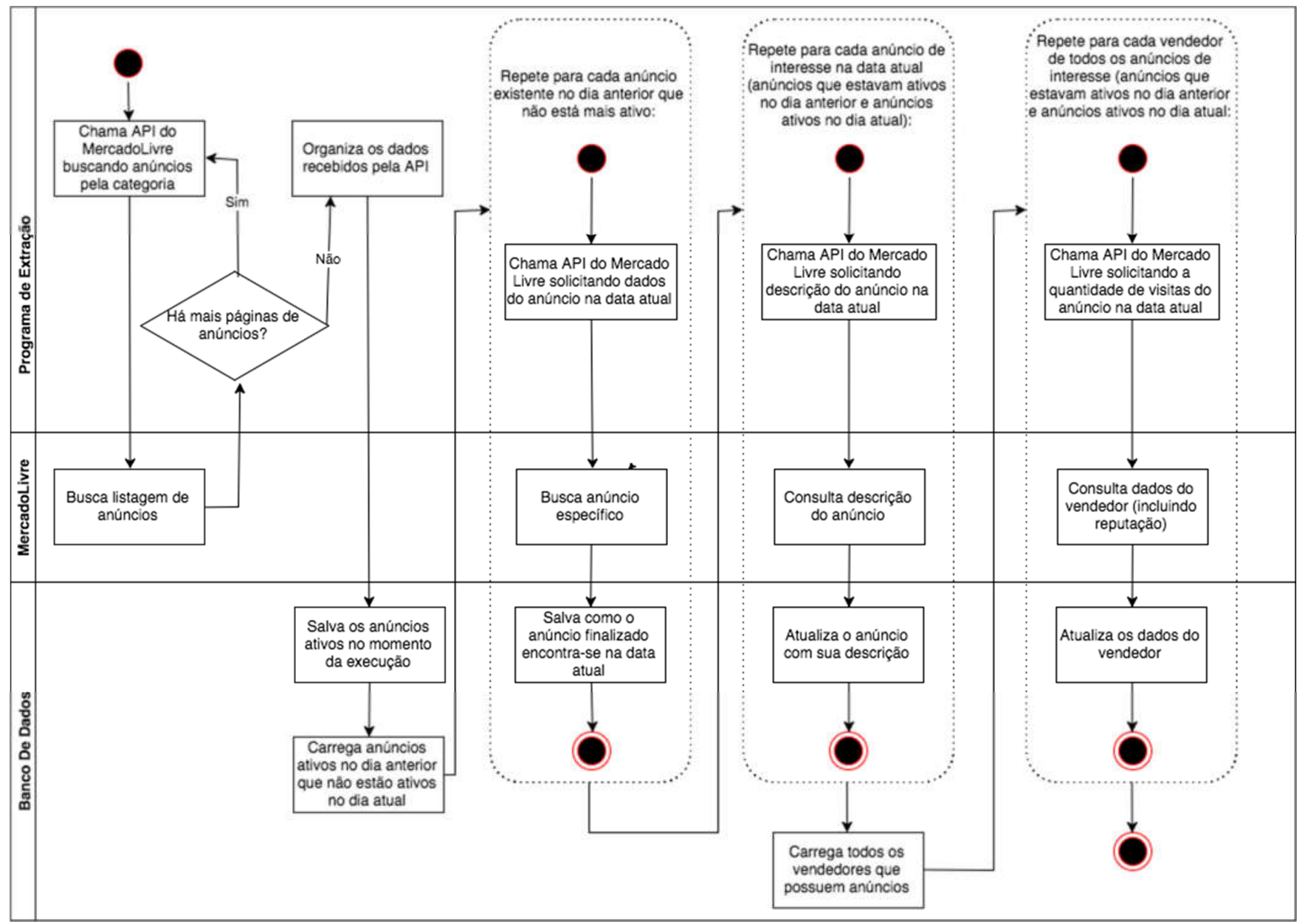

Fonte: Elaborado pelo autor. 


\subsubsection{Geração do extrato de vendas}

Diferente do que acontece com a extração dos anúncios e informações dos vendedores, que precisa ser executado diariamente, o script que transforma estes dados no extrato de vendas pode ser executado apenas uma vez, ao final do processo. Assim, após da extração, no dia 01/03/2017, é executado um script que, seguindo a lógica já apresentada na Figura 13, compara linha a linha todos os anúncios e elabora o extrato de vendas, criando no extrato uma linha para cada venda. Isto é, se no anúncio for detectado que houve três vendas em um dia específico, são criadas três linhas similares na tabela (alterando-se apenas alguns valores que logicamente sofreram alteração a cada venda, como a quantidade de vendas realizadas por aquele anúncio e o total de vendas realizadas pelo vendedor até o momento de cada compra).

Tecnicamente esta etapa ocorreria diretamente no banco de dados originalmente elaborado, MySQL. Mas por questões operacionais, devido a complexidade do código, os dados foram migrados para um banco SQL Server e o script escrito para este banco.

Além de identificar os dias em que ocorreram as vendas e quais eram os valores de cada variável neste dia, nesta etapa também são criadas algumas variáveis a partir dos dados existentes. Por exemplo, nos dados inicialmente extraídos consta a cidade a partir de onde será efetuado o envio do item. O script utiliza esta informação para criar uma variável "is_capital" que informa se trata-se de uma capital ou interior.

A Tabela 14 apresenta o resultado final desta execução.

Tabela 14 - Variáveis existentes no extrato de vendas

\begin{tabular}{|l|l|l|l|}
\hline $\begin{array}{l}\text { Variável no } \\
\text { Extrato }\end{array}$ & Exemplo & Comentário & Variável no Modelo \\
\hline sale_date & $\begin{array}{l}2017-01- \\
\text { MLB } \\
820994585\end{array}$ & $\begin{array}{l}\text { Identificador único do } \\
\text { anúncio no site do Mercado } \\
\text { Livre. }\end{array}$ & \\
\hline id_ad & & \\
\hline
\end{tabular}




\begin{tabular}{|c|c|c|c|}
\hline title & $\begin{array}{l}\text { Apple } \\
\text { Iphone } 6 \\
16 \mathrm{gb} \mathrm{4g} \mathrm{\ldots ..}\end{array}$ & $\begin{array}{l}\text { Título do anúncio (cortado } \\
\text { nesta tabela apenas por } \\
\text { questões de tamanho) }\end{array}$ & \\
\hline price & 1749,90 & Preço da venda. & Preço \\
\hline qty_sold & 3 & $\begin{array}{l}\text { Quantidade de vendas que já } \\
\text { haviam sido realizadas } \\
\text { anteriormente naquele } \\
\text { mesmo anúncio. }\end{array}$ & QTDVENDAANUN \\
\hline type_goldpro & 0 & $\begin{array}{l}\text { Indica se o anúncio paga por } \\
\text { exposição adicional do tipo } \\
\text { "Clássico". } \\
\text { possíveis: } 1 \text { (sim) ou } 0 \text { (não). }\end{array}$ & TIPODOANUNCIO \\
\hline type_goldspecial & 1 & $\begin{array}{l}\text { Indica se o anúncio paga por } \\
\text { exposição adicional do tipo } \\
\text { "Premium". Valores } \\
\text { possíveis: } 1 \text { (sim) ou } 0 \text { (não). }\end{array}$ & $\begin{array}{l}\text { TIPODO- } \\
\text { ANUNCIO }\end{array}$ \\
\hline days_start_to_sale & 17 & $\begin{array}{l}\text { Número de dias contados a } \\
\text { partir da publicação do } \\
\text { anúncio até a realização da } \\
\text { venda. }\end{array}$ & $\begin{array}{l}\text { IDADEDO- } \\
\text { ANÚNCIO }\end{array}$ \\
\hline video & 0 & $\begin{array}{l}\text { Indica se o anúncio possui } \\
\text { vídeo. Valores possíveis: } 1 \\
(\operatorname{sim}) \text { ou } 0 \text { (não). }\end{array}$ & VIDEO \\
\hline delivery_me2 & 1 & $\begin{array}{l}\text { Indica se o vendedor envia } \\
\text { por MercadoEnvios. Valores } \\
\text { possíveis: } 1 \text { (sim) ou } 0 \text { (não). }\end{array}$ & MERCADOENVIOS \\
\hline delivery_free & 0 & $\begin{array}{l}\text { Indica se frete é gratuito } \\
\text { (vendedor arca com os } \\
\text { custos). Valores possíveis: } 1 \\
\text { (sim) ou } 0 \text { (não). }\end{array}$ & FRETEGRATIS \\
\hline warranty & 1 & $\begin{array}{l}\text { Indica se o vendedor oferece } \\
\text { alguma garantia adicional. }\end{array}$ & GARANTIA \\
\hline
\end{tabular}




\begin{tabular}{|c|c|c|c|}
\hline & & $\begin{array}{l}\text { Valores possíveis: } 1 \text { (sim) ou } \\
0 \text { (não). }\end{array}$ & \\
\hline qty_photos & 6 & $\begin{array}{l}\text { Número de fotos que existem } \\
\text { no anúncio. }\end{array}$ & QTDFOTOS \\
\hline city_is_capital & 1 & $\begin{array}{l}\text { Indica se o vendedor está em } \\
\text { uma capital ou interior. } \\
\text { Valores possíveis: } 1 \text { (capital) } \\
\text { ou } 0 \text { (interior). }\end{array}$ & NACAPITAL \\
\hline seller_name & $\begin{array}{l}\text { ARENA } \\
\text { SHOPPP }\end{array}$ & & \\
\hline seller_age & 2007 & $\begin{array}{l}\text { Número de dias desde a } \\
\text { criação da conta até a } \\
\text { realização da venda. }\end{array}$ & IDADEVENDEDOR \\
\hline oficial_store & 0 & $\begin{array}{l}\text { Indica se o vendedor é uma } \\
\text { loja oficial. Valores } \\
\text { possíveis: } 1 \text { (sim) ou } 0 \text { (não). }\end{array}$ & LOJAOFICIAL \\
\hline $\begin{array}{l}\text { seller_rep } \\
\text { power_silver }\end{array}$ & 0 & $\begin{array}{l}\text { Indica se o vendedor é um } \\
\text { MercadoLíder do primeiro } \\
\text { nível. Valores possíveis: } 1 \\
\text { (sim) ou } 0 \text { (não). }\end{array}$ & MERCADOLIDER \\
\hline $\begin{array}{l}\text { seller_rep } \\
\text { power_gold }\end{array}$ & 0 & $\begin{array}{l}\text { Indica se o vendedor é um } \\
\text { MercadoLíder do nível } \\
\text { "gold". Valores possíveis: } 1 \\
\text { (sim) ou } 0 \text { (não). }\end{array}$ & MERCADOLIDER \\
\hline $\begin{array}{l}\text { seller_rep } \\
\text { power_platinum }\end{array}$ & 1 & $\begin{array}{l}\text { Indica se o vendedor é um } \\
\text { MercadoLíder do nível } \\
\text { "Platinum". } \\
\text { possíveis: } 1 \text { (sim) ou } 0 \text { (não). }\end{array}$ & MERCADOLIDER \\
\hline seller_rep_level_1 & 0 & $\begin{array}{l}\text { Indica se, no termômetro do } \\
\text { Mercado Livre, este } \\
\text { vendedor possui reputação } \\
\text { nível } 1 \text { (vermelho). Valores } \\
\text { possíveis: } 1 \text { (sim) ou } 0 \text { (não). }\end{array}$ & TERMOMETRO \\
\hline
\end{tabular}




\begin{tabular}{|c|c|c|c|}
\hline seller_rep_level_2 & 0 & $\begin{array}{l}\text { Indica se, no termômetro do } \\
\text { Mercado Livre, este } \\
\text { vendedor possui reputação } \\
\text { nível } 1 \text { (laranja). Valores } \\
\text { possíveis: } 1 \text { (sim) ou } 0 \text { (não). }\end{array}$ & TERMOMETRO \\
\hline seller_rep_level_3 & 0 & $\begin{array}{l}\text { Indica se, no termômetro do } \\
\text { Mercado Livre, este } \\
\text { vendedor possui reputação } \\
\text { nível } 1 \text { (amarelo). Valores } \\
\text { possíveis: } 1 \text { (sim) ou } 0 \text { (não). }\end{array}$ & TERMOMETRO \\
\hline seller_rep_level_4 & 0 & $\begin{array}{l}\text { Indica se, no termômetro do } \\
\text { Mercado Livre, este } \\
\text { vendedor possui reputação } \\
\text { nível } 1 \text { (verde claro). Valores } \\
\text { possíveis: } 1 \text { (sim) ou } 0 \text { (não). }\end{array}$ & TERMOMETRO \\
\hline seller_rep_level_5 & 1 & $\begin{array}{l}\text { Indica se, no termômetro do } \\
\text { Mercado Livre, este } \\
\text { vendedor possui reputação } \\
\text { nível } 1 \text { (verde escuro). } \\
\text { Valores possíveis: } 1 \text { (sim) ou } \\
0 \text { (não). }\end{array}$ & TERMOMETRO \\
\hline $\begin{array}{l}\text { seller_rep } \\
\text { trans_complete }\end{array}$ & 2576 & $\begin{array}{l}\text { Quantidade de vendas bem- } \\
\text { sucedidas realizadas } \\
\text { anteriormente pelo vendedor. }\end{array}$ & $\begin{array}{l}\text { TRANSACOES- } \\
\text { COMPLETAS }\end{array}$ \\
\hline seller_rep_points & 1936 & $\begin{array}{l}\text { Soma de todos os pontos } \\
\text { obtidos pelo usuário } \\
\text { vendedor com suas compras } \\
\text { e vendas. Cada avaliação } \\
\text { positiva equivale a mais um } \\
\text { ponto e negativa a menos um } \\
\text { ponto. }\end{array}$ & PONTVENDEDOR \\
\hline $\begin{array}{l}\text { seller_rep } \\
\text { trans_point_neg }\end{array}$ & 0.01 & $\begin{array}{l}\text { Percentual das vendas } \\
\text { anteriores do vendedor que }\end{array}$ & $\begin{array}{l}\text { PERCENT- } \\
\text { NEGATIVO }\end{array}$ \\
\hline
\end{tabular}




\begin{tabular}{|c|c|c|c|}
\hline & & $\begin{array}{l}\text { foram avaliadas } \\
\text { negativamente. Valores entre } \\
0 \text { e } 1 .\end{array}$ & \\
\hline item_condition_new & 1 & $\begin{array}{l}\text { Estado do item que está } \\
\text { sendo anunciado. Valores } \\
\text { possíveis: } 1 \text { (novo) ou } 0 \\
\text { (usado). }\end{array}$ & ESTADODOITEM \\
\hline keyword_nota & 0 & $\begin{array}{l}\text { Indica se em algum momento } \\
\text { no título ou na descrição são } \\
\text { mencionados os termos NF, } \\
\text { NFE, Nota ou Nota Fiscal }\end{array}$ & EMITENF \\
\hline keyword_caixa & 0 & $\begin{array}{l}\text { Indica se em algum momento } \\
\text { no título ou na descrição são } \\
\text { mencionados os termos } \\
\text { "caixa" (para qualquer } \\
\text { produto) ou "sacola" (apenas } \\
\text { para o tênis) }\end{array}$ & NACAIXA \\
\hline is_ps4 & 0 & $\begin{array}{l}\text { Indica se o item anunciado é } \\
\text { um Playstation } 4 \text {. Valores } \\
\text { possíveis: } 1 \text { (sim) ou } 0 \text { (não). }\end{array}$ & $\begin{array}{l}\text { Característica do } \\
\text { produto }\end{array}$ \\
\hline is_tenis & 0 & $\begin{array}{l}\text { Indica se o item anunciado é } \\
\text { um tênis. Valores possíveis: } \\
1 \text { (sim) ou } 0 \text { (não). }\end{array}$ & $\begin{array}{l}\text { Característica do } \\
\text { produto }\end{array}$ \\
\hline
\end{tabular}

Fonte: Elaborado pelo autor.

Apesar de todos os valores representarem como o anúncio ou o vendedor encontravam-se no início do dia em que foi realizada a venda, se duas vendas forem realizadas no mesmo dia, um tratamento é aplicado nas variáveis diretamente afetadas por este fato. Mais especificamente, é feito um incremento no "qty_sold" e em "seller_rep_trans_complete" entre a primeira venda e a segunda. Ou seja, no exemplo do anúncio MLB820994585, a Tabela 14 mostra os valores da primeira venda realizada no dia 02/01/2017. No mesmo dia foi realizada uma segunda venda e, para esta, o valor de “qty_sold” está 4 e o “seller_rep_trans_complete” está 2577. 
Além das variáveis listadas na Tabela 14, pequenas modificações foram realizadas de acordo com o produto. No caso dos iPhones, parte dos anúncios destacava em sua descrição a presença da caixa do produto ou do envio com nota fiscal. Foram incluídas duas variáveis "keyword_caixa" e "keyword_nota", ambas com valores possíveis 0 (não) ou 1 (sim), indicando se há explicitamente no texto da descrição ou no título palavras que indiquem o envio da caixa ou da nota, respectivamente.

Para os anúncios de Playstation 4, dentro da mesma categoria existem videogames com capacidade de armazenamento diferentes. Foi criada uma variável "tb1" indicando a capacidade de armazenamento, sendo 0 caso seja de 500 gigabytes e 1 caso seja de 1 terabyte. Além disso, é pratica comum na venda deste produto o envio de produtos complementares como jogos ou controles adicionais. Uma variável "controle2" foi incluída para indicar se o produto acompanha um controle adicional. Estas variáveis foram preenchidas manualmente, com auxílio de ferramentas para buscar palavras-chave no título e descrição. 


\section{ANÁLISE DOS RESULTADOS}

Ao longo dos 56 dias foram coletados dados de 17133 vendas. Entre estas vendas, no entanto, estão anúncios mal categorizados, que não representam de fato os produtos de interesse deste trabalho. Se fez necessária, então, uma revisão e limpeza das vendas para excluir aquelas que não deveriam constar na relação.

\subsection{Limpeza dos dados}

O primeiro filtro foi realizado com base no preço. Foram desconsideradas todas vendas de iPhone com valor inferior a $\mathrm{R} \$ 500,00$ e superior a $\mathrm{R} \$ 2.500,00$, as vendas de Playstation 4 com valor inferior a $\mathrm{R} \$ 500,00$ e superior a $\mathrm{R} \$ 2.500$ e as vendas de tênis com valor inferior a $\mathrm{R} \$ 50,00$ e superior a $\mathrm{R} \$ 200,00$.

Com isso, foi possível limpar casos como, por exemplo, de duas vendas na categoria dos iPhones que ocorreram uma por $\mathrm{R} \$ 1,00$ e a outra por $\mathrm{R} \$ 5,00$. Estas vendas são, na verdade, uma propaganda disfarçada. $\mathrm{O}$ vendedor havia anunciado um guia sobre como conseguir comprar iPhones com desconto. Existem também casos de vendedores que, intencionalmente ou não, classificam seus produtos na categoria incorreta. É o caso dos anúncios de acessórios para iPhone. Vendedores de capas, fones e carregadores, colocam seus produtos na categoria "iPhone 6 16gb" possivelmente na expectativa de atingir as pessoas que estão comprando um celular novo e também podem se interessar pelos acessórios. O mesmo ocorre com jogos e controles de Playstation 4 anunciados na categoria do console.

No limite superior são excluídos principalmente vendas de lotes de produtos, como o caso de uma venda do anúncio MLB825827543 cujo título é "2 Iphones 6 Com Excelente Preço" ou da venda do anúncio MLB830636540, intitulado "Vendo Dois Playstation 4".

Além da filtragem por preços, foi feita uma limpeza com base no conteúdo dos títulos. Da mesma forma que vendedores anunciam produtos complementares na mesma categoria, há casos de vendedores que anunciam produtos substitutos. Entre as vendas dos iPhones 6 de 16gb,

há diversos casos de outros modelos de iPhone $(5,5 \mathrm{~s}, 6 \mathrm{~s}, 7$, com mais armazenamento etc.) e de celulares Android. Em meio às vendas de Playstation 4, há vendas de consoles Xbox e da versão Playstation 4 Pro (mais nova, com melhor resolução e mais cara) e do Playstation VR (acessório de realidade virtual). 
Buscas por palavras-chaves nos títulos dos anúncios que indicassem estas possibilidades foram efetuadas e, manualmente, o extrato de vendas foi revisado para excluir estes casos. Também foram excluídos anúncios de itens defeituosos, que não funcionam. Os itens que apresentam pequenos defeitos ou arranhões foram mantidos, excluindo-se apenas os que afirmam possuir problemas que impendem o seu uso.

Entre as vendas de iPhones foram identificadas três transações cujo valor do anúncio não corresponde ao valor de fato praticado e, por isso, também foram excluídos. Em um deles, o vendedor colocou o anúncio por $\mathrm{R} \$ 500,00$ mas deixou um aviso que o preço real seria $\mathrm{R} \$ 1.350,00$ e que só fecharia o negócio por fora do Mercado Livre, através de seu e-mail. Nos outros dois, os vendedores alteraram o preço a pedido do comprador para que o pagamento fosse feito em duas partes. Em um dos anúncios, um pagamento seria feito em dinheiro no momento da entrega. No outro, o preço do anúncio original foi reduzido e foi criado um segundo anúncio, com a diferença do valor, para que o comprador complementasse o pagamento. A intenção desta manobra é permitir que o comprador utilize mais de um cartão para efetuar o pagamento dentro da plataforma do Mercado Livre. Entre os anúncios excluídos por terem um valor muito baixo há diversos outros casos similares.

Ocorreram ainda 612 casos, cujos dados coletados apresentaram-se incompletos devido a falha técnica no momento da coleta. Estas vendas também foram descartadas. A Tabela 15 apresenta quantas vendas foram descartadas por cada motivo, para cada produto.

Tabela 15 - Detalhamento da limpeza dos dados

\begin{tabular}{|l|c|c|l|l|l|}
\hline $\begin{array}{l}\text { Produto - } \\
\text { Classificação }\end{array}$ & N & $\begin{array}{l}\text { N \% por } \\
\text { produto }\end{array}$ & $\begin{array}{l}\text { Preço } \\
\text { Mínimo }\end{array}$ & $\begin{array}{l}\text { Preço } \\
\text { Médio }\end{array}$ & $\begin{array}{l}\text { Preço } \\
\text { Máximo }\end{array}$ \\
\hline PS4 & $\mathbf{1 3 6 1 2}$ & $\mathbf{1 0 0 , 0 0 \%}$ & $\mathbf{R} \$ 1,00$ & $\mathbf{R} \$ 1.361,46$ & $\mathbf{R} \$ \mathbf{2 5 . 7 7 0 , 0 0}$ \\
\hline $\begin{array}{c}\text { Excluído - Produto } \\
\text { defeituoso }\end{array}$ & 12 & $0,09 \%$ & $\mathrm{R} \$ 500,00$ & $\mathrm{R} \$ 673,83$ & $\mathrm{R} \$ 1,500.00$ \\
\hline $\begin{array}{c}\text { Excluído - Outro } \\
\text { produto }\end{array}$ & 55 & $0,40 \%$ & $\mathrm{R} \$ 600,00$ & $\mathrm{R} \$ 1.180,23$ & $\mathrm{R} \$ 2,200.00$ \\
\hline $\begin{array}{c}\text { Excluído - Outro } \\
\text { produto (PS VR) }\end{array}$ & 2 & $0,01 \%$ & $\mathrm{R} \$ 2.200,00$ & $\mathrm{R} \$ 2.200,00$ & $\mathrm{R} \$ 2,200.00$ \\
\hline
\end{tabular}




\begin{tabular}{|c|c|c|c|c|c|}
\hline $\begin{array}{l}\text { Excluído - Abaixo } \\
\text { de } \mathrm{R} \$ 500,00\end{array}$ & 1255 & $9,22 \%$ & $\mathrm{R} \$ 1,00$ & $\mathrm{R} \$ 15,48$ & $\mathrm{R} \$ 487.00$ \\
\hline $\begin{array}{l}\text { Excluído - Acima } \\
\text { de } \mathrm{R} \$ 2.500,00\end{array}$ & 126 & $0,93 \%$ & $\mathrm{R} \$ 2.510,00$ & $\mathrm{R} \$ 3.187,01$ & $\mathrm{R} \$ 25,770.00$ \\
\hline $\begin{array}{l}\text { Excluído - Outro } \\
\text { produto (Ps4 Pro) }\end{array}$ & 1237 & $9,09 \%$ & $\mathrm{R} \$ 1.300,00$ & $\mathrm{R} \$ 2.177,22$ & $\mathrm{R} \$ 2,500.00$ \\
\hline $\begin{array}{l}\text { Excluído - Dados } \\
\text { incompletos }\end{array}$ & 565 & $4,15 \%$ & $\mathrm{R} \$ 1.098,00$ & $\mathrm{R} \$ 1.389,89$ & $\mathrm{R} \$ 2,499.00$ \\
\hline Dados válidos & 10360 & $76,10 \%$ & $\mathrm{R} \$ 500,00$ & $\mathrm{R} \$ 1.404,95$ & $\mathrm{R} \$ 2,500.00$ \\
\hline iPhone & 2633 & $100,00 \%$ & $\mathrm{R} \$ 4,90$ & R\$1.629,23 & R\$5,499.99 \\
\hline $\begin{array}{l}\text { Excluído - Produto } \\
\text { defeituoso }\end{array}$ & 48 & $0,28 \%$ & $\mathrm{R} \$ 500,00$ & $\mathrm{R} \$ 748,94$ & $\mathrm{R} \$ 1.350,00$ \\
\hline $\begin{array}{l}\text { Excluído - Outro } \\
\text { produto }\end{array}$ & 12 & $0,46 \%$ & $\mathrm{R} \$ 500,00$ & $\mathrm{R} \$ 946,59$ & $\mathrm{R} \$ 1.850,00$ \\
\hline $\begin{array}{l}\text { Excluído - Preço } \\
\text { do anúncio diferente } \\
\text { do preço praticado }\end{array}$ & 3 & $0,12 \%$ & $\mathrm{R} \$ 500,00$ & $\mathrm{R} \$ 666,67$ & $\mathrm{R} \$ 750,00$ \\
\hline $\begin{array}{l}\text { Excluído - Outro } \\
\text { produto (iPhone de } \\
\text { modelo diferente) }\end{array}$ & 385 & $14,87 \%$ & $\mathrm{R} \$ 500,00$ & $\mathrm{R} \$ 2.012,34$ & $\mathrm{R} \$ 2.499,00$ \\
\hline $\begin{array}{l}\text { Excluído - Abaixo } \\
\text { de } \mathrm{R} \$ 500,00\end{array}$ & 356 & $13,75 \%$ & $\mathrm{R} \$ 4,90$ & $\mathrm{R} \$ 256,69$ & $\mathrm{R} \$ 470,00$ \\
\hline $\begin{array}{l}\text { Excluído - Acima } \\
\text { de } \mathrm{R} \$ 2.500,00\end{array}$ & 71 & $2,74 \%$ & $\mathrm{R} \$ 2.549,99$ & $\mathrm{R} \$ 2.833,57$ & $\mathrm{R} \$ 5.499,99$ \\
\hline $\begin{array}{l}\text { Excluído - Dados } \\
\text { incompletos }\end{array}$ & 29 & $1,12 \%$ & $\mathrm{R} \$ 1.500,00$ & $\mathrm{R} \$ 1.852,64$ & $\mathrm{R} \$ 2.000,00$ \\
\hline Dados Válidos & 1729 & $66,78 \%$ & $\mathrm{R} \$ 800,00$ & $\mathrm{R} \$ 1,804.17$ & $\mathrm{R} \$ 2.500,00$ \\
\hline Tênis & 888 & $100,00 \%$ & R\$29,99 & R\$112,88 & $\mathrm{R} \$ 2.023,65$ \\
\hline $\begin{array}{l}\text { Excluído - Abaixo } \\
\text { de } \mathrm{R} \$ 50,00\end{array}$ & 13 & $1,46 \%$ & $\mathrm{R} \$ 29,99$ & $\mathrm{R} \$ 33,75$ & $\mathrm{R} \$ 42,99$ \\
\hline $\begin{array}{l}\text { Excluído - Acima } \\
\text { de } \mathrm{R} \$ 200,00\end{array}$ & 9 & $1,1 \%$ & $\mathrm{R} \$ 204,90$ & $\mathrm{R} \$ 442,67$ & $\mathrm{R} \$ 2.023,65$ \\
\hline
\end{tabular}




\begin{tabular}{|c|c|c|l|l|l|}
$\begin{array}{c}\text { Excluído - Dados } \\
\text { incompletos }\end{array}$ & 17 & $1,91 \%$ & $\mathrm{R} \$ 69,99$ & $\mathrm{R} \$ 101,82$ & $\mathrm{R} \$ 149,90$ \\
\hline Dados Válidos & 849 & $95,61 \%$ & $\mathrm{R} \$ 59,90$ & $\mathrm{R} \$ 110,82$ & $\mathrm{R} \$ 200,00$ \\
\hline
\end{tabular}

Fonte: Elaborado pelo autor.

A Figura 16 mostra o total de linhas no extrato de vendas ao término de cada etapa do processo de limpeza, e o total de dados válidos que foram utilizados neste estudo.

Figura 16 - Limpeza dos dados não desejados

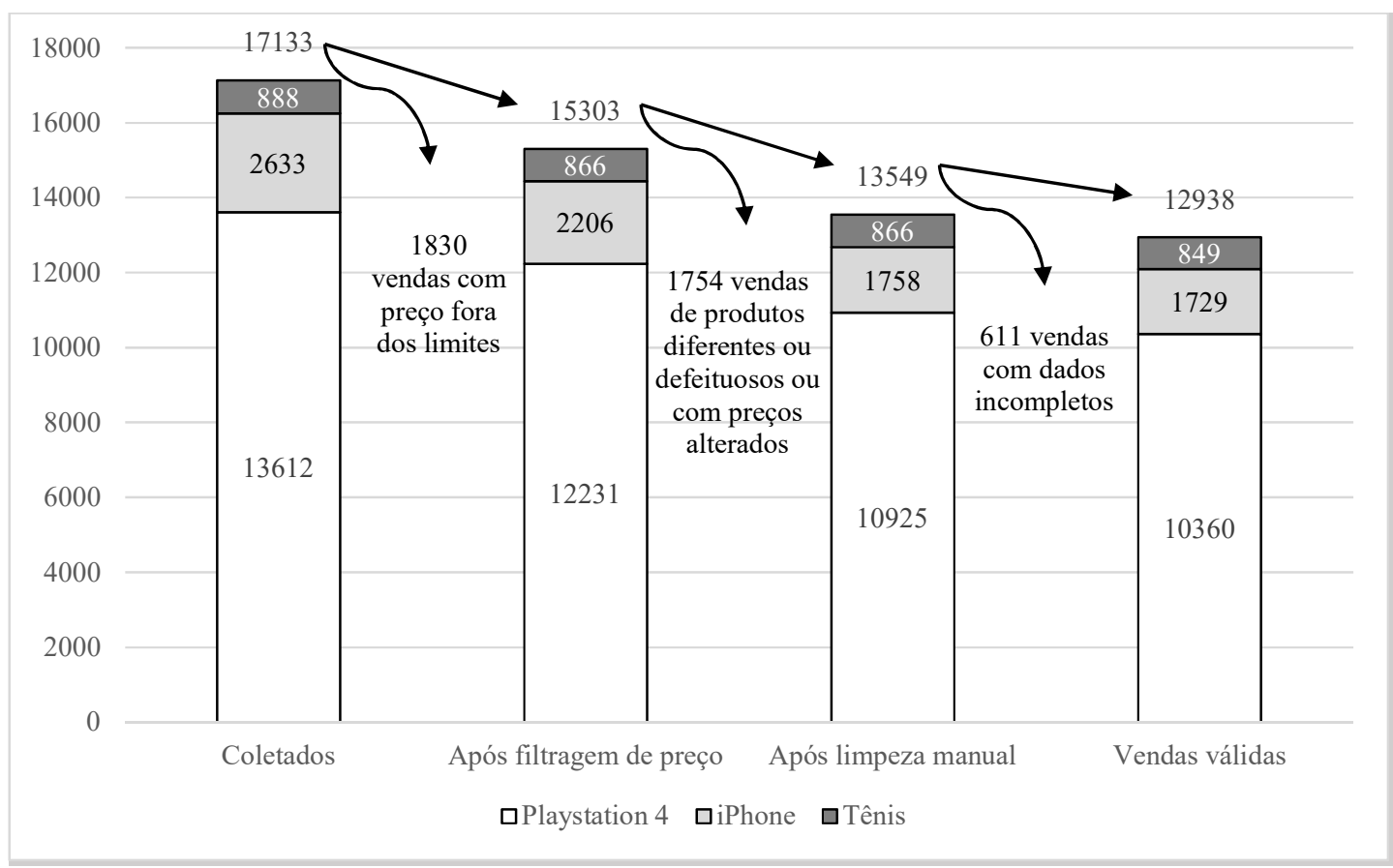

Fonte: Elaborado pelo autor.

\subsection{Apresentação dos dados}

Após a limpeza dos dados, um arquivo contendo as 12.938 vendas foi gerado e importado para a ferramenta $\mathrm{R}$, onde foram realizadas as análises. Para cada produto vendido, foram geradas estatísticas descritivas dos fatores apresentados anteriormente na Tabela 14. Estas informações, que incluem a quantidade de vendas em cada categoria (para as variáveis categóricas) e os valores mínimo, do primeiro quadrante, da mediana, média, terceiro quadrante e máximo (para as variáveis quantitativas), foram tabuladas para uma melhor apresentação e são expostas a seguir. 


\subsubsection{Vendas de iPhone}

As informações apresentadas nesta seção foram extraídas das 1729 vendas de iPhones que ocorreram no período. Na Tabela 17 observa-se que a maioria das vendas foi realizada através de anúncios pagos do tipo Clássico, seguido dos anúncios Premium e só então os gratuitos. Há casos de vendas em anúncios com vídeo, apesar de $89 \%$ não ter utilizado este recurso. Já em relação ao uso de fotos, apesar de terem ocorrido vendas em anúncios sem fotos, em média as vendas foram realizadas por publicações com 4 fotos. Em mais da metade das vendas deste celular os custos do frete foram pagos pelo vendedor. Em $60,8 \%$ dos casos o anunciante encontrava-se em uma capital.

Tabela 16 - Características dos anúncios nas vendas de iPhones

\begin{tabular}{|c|c|c|c|c|c|c|}
\hline \multirow{2}{*}{$\begin{array}{l}\text { TIPODO- } \\
\text { ANUNCIO }\end{array}$} & Gratuito & Gra. \% & Clássico & Cl. \% & Premium & Prem. \% \\
\hline & 330 & 0,191 & 1095 & 0,633 & 304 & 0,176 \\
\hline VIDEO & \multicolumn{2}{|c|}{ Sim } & Sim \% & Não & \multicolumn{2}{|c|}{ Não \% } \\
\hline & \multicolumn{2}{|c|}{191} & 0,110 & 1538 & \multicolumn{2}{|c|}{0,890} \\
\hline MERCADO- & \multicolumn{2}{|c|}{ Sim } & Sim \% & Não & \multicolumn{2}{|c|}{ Não \% } \\
\hline ENVIOS & \multicolumn{2}{|c|}{1648} & 0,953 & 81 & \multicolumn{2}{|c|}{0,047} \\
\hline FRETE- & \multicolumn{2}{|c|}{ Sim } & Sim \% & Não & \multicolumn{2}{|c|}{ Não \% } \\
\hline GRATUITO & \multicolumn{2}{|c|}{1064} & 0,615 & 665 & \multicolumn{2}{|c|}{0,385} \\
\hline \multirow[t]{2}{*}{ GARANTIA } & \multicolumn{2}{|c|}{ Sim } & Sim \% & Não & \multicolumn{2}{|c|}{ Não \% } \\
\hline & \multicolumn{2}{|c|}{1169} & 0,676 & 560 & \multicolumn{2}{|c|}{0,324} \\
\hline IDADEDO- & Mínimo & Prim. Quad. & Mediana & Média & Terc. Quad. & Máximo \\
\hline ANUNCIO & 0 & 10 & 36 & 67,91 & 88 & 556 \\
\hline QTDFOTOS & Mínimo & Prim. Quad. & Mediana & Média & Terc. Quad. & Máximo \\
\hline & 0 & 3 & 4 & 4,3 & 6 & 14 \\
\hline EMITENF & Sim & & im \% & Não & & \\
\hline & 274 & & 0,158 & 1455 & & \\
\hline QTDVEND- & Mínimo & Prim. Quad. & Mediana & Média & Terc. Quad. & Máximo \\
\hline ANUN & 0 & 0 & 10 & 25,68 & 42 & 253 \\
\hline
\end{tabular}

Fonte: Elaborado pelo autor. 
A Tabela 18 apresenta as características dos vendedores nas vendas que ocorreram no período. Foram realizadas vendas tanto por vendedores experientes, com até 120.000 transações anteriores, quanto por vendedores novos que estavam realizando sua primeira venda (média de 6368 transações anteriores e mediana de 344). Quanto ao tempo em que os vendedores utilizam a plataforma, também foram observados vendedores novos, com apenas um dia de conta, e vendedores antigos cujas contas existem há 17 anos, ou seja, foram criadas no primeiro ano de operação do Mercado Livre.

Tabela 17 - Características dos vendedores nas vendas de iPhones

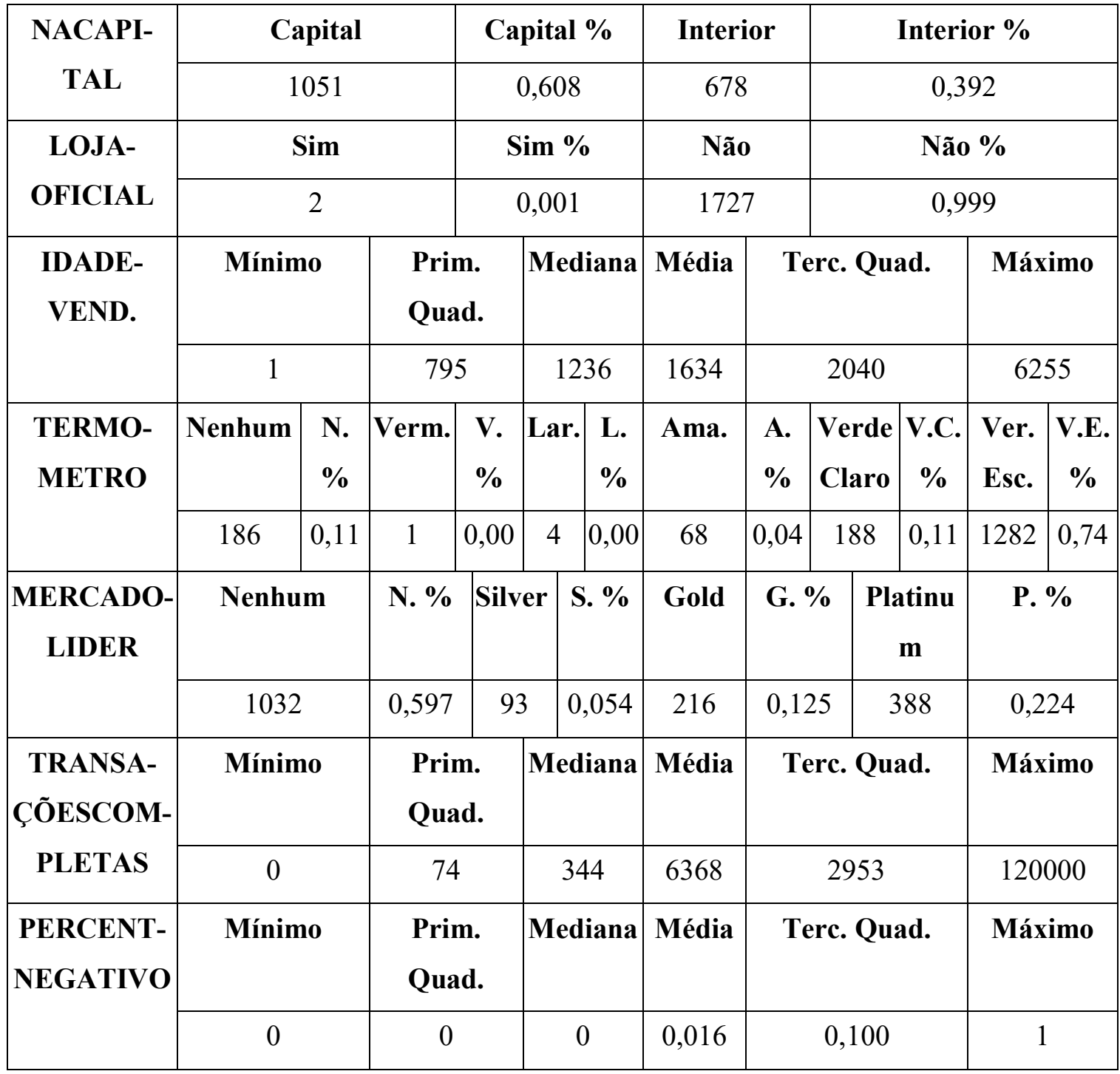

Fonte: Elaborado pelo autor. 
Observa-se na Tabela 18, em relação ao preços das vendas, que a mediana e a média possuem valores bem próximos, sendo respectivamente $\mathrm{R} \$ 1.800,00$ e $\mathrm{R} \$ 1.804,17$.

Tabela 18 - Variação de preços nas vendas de iPhones

\begin{tabular}{|c|c|c|c|c|c|c|}
\hline \multirow{2}{*}{ Preço } & Mínimo & $\begin{array}{c}\text { Prim. } \\
\text { Quad. }\end{array}$ & Mediana & Média & Terc. Quad. & Máximo \\
\cline { 2 - 6 } & 800 & 1680 & 1800 & 1804,17 & 1979 & 2500 \\
\hline
\end{tabular}

Fonte: Elaborado pelo autor.

A Figura 17 apresenta um gráfico com a frequência dos valores das vendas realizadas.

Figura 17 - Distribuição de freqüencia dos preços das vendas de iPhone

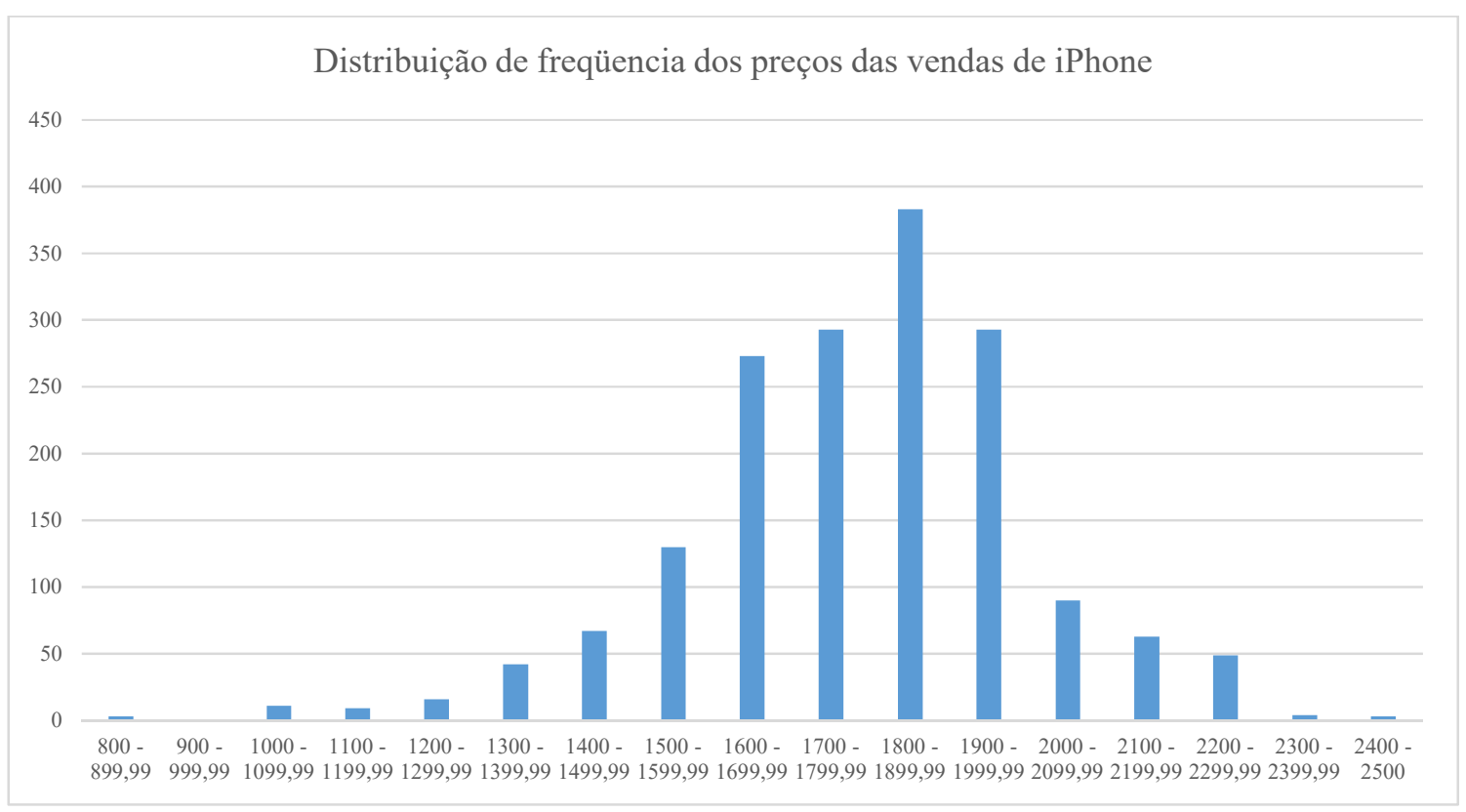

Fonte: Elaborado pelo autor

Observa-se que a maioria das vendas foi realizada por valores entre $\mathrm{R} \$ 1.700$ e $\mathrm{R} \$ 1999,99$. A moda foi 1.899,00 e o desvio padrão R $\$ 230,58$. A distribuição é quase simétrica, com pequena assimetria negativa (coeficiente -0,52). A venda de telefones usados, que representou $58,7 \%$ do total de vendas, como apresentado na Tabela 19, contribui com esta assimetria. 
Tabela 19 - Características do produto nas vendas de iPhones

\begin{tabular}{|c|c|c|c|c|}
\hline \multirow{2}{*}{$\begin{array}{c}\text { ESTADO- } \\
\text { ITEM }\end{array}$} & Novo & Novo \% & Usado & Usado \% \\
\cline { 2 - 5 } & 714 & 0,413 & 1015 & 0,587 \\
\hline \multirow{2}{*}{ NACAIXA } & Sim & Sim \% & Não & Não \% \\
\cline { 2 - 5 } & 615 & 0,356 & 1114 & 0,644 \\
\hline
\end{tabular}

Fonte: Elaborado pelo autor.

A Figura 18 apresenta um gráfico boxplot dos valores das vendas de iPhone, dividindo-as entre vendas de telefones usados e novos. Nela observa-se que a linha que indica a mediana dos valores está muito próxima ao centro do quadrado para os iPhones novos. Já para os aparelhos usados, além da amplitude do retângulo ser maior, a linha da mediana está mais próxima de Q3.

Figura 18 - Boxplot dos preços das vendas de iPhones novos e usados

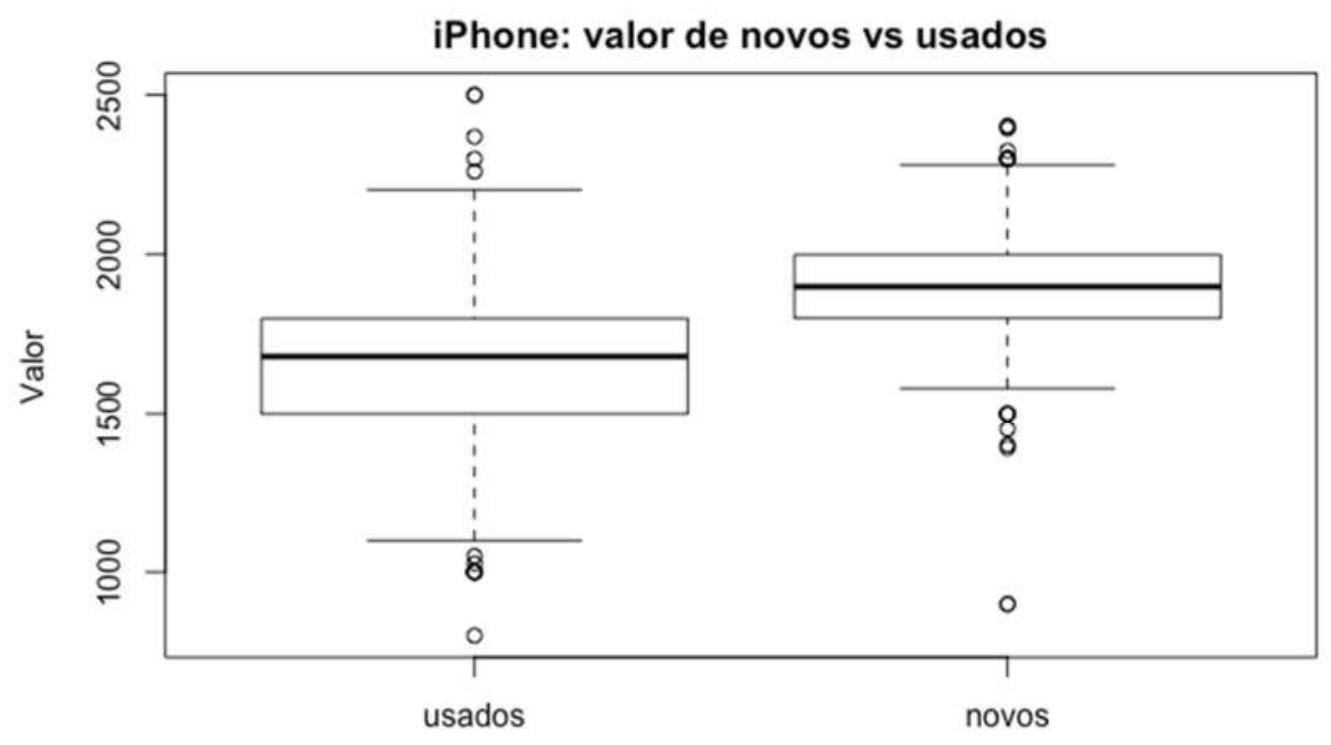

Novo ou Usado

Fonte: Elaborado pelo autor

Em média, os valores das vendas que ocorreram no Mercado Livre foram ligeiramente inferiores aos valores ofertados pelas lojas virtuais tradicionais. Considerando-se apenas os aparelhos novos, o valor médio das vendas foi de $\mathrm{R} \$ 1905,96$. A Apple não divulga um preço oficial para o aparelho em questão, pois ela comercializa em seu site apenas as versões mais novas. Atualmente este modelo é comercializado no site do MagazineLuiza por R\$2.299,00 
para compras no cartão ou $\mathrm{R} \$ 2069,91^{8}$ para pagamentos em boleto. A ferramenta de comparação de preços Zoom ${ }^{9}$ registrou o menor preço ofertado nos principais sites de ecommerce a cada semana em um período de seis meses e encontrou valores entre $\mathrm{R} \$ 1.799,99$ e R\$2.299,00 (Figura 19).

Figura 19 - Variação do preço ofertado dos iPhones nas lojas virtuais tradicionais

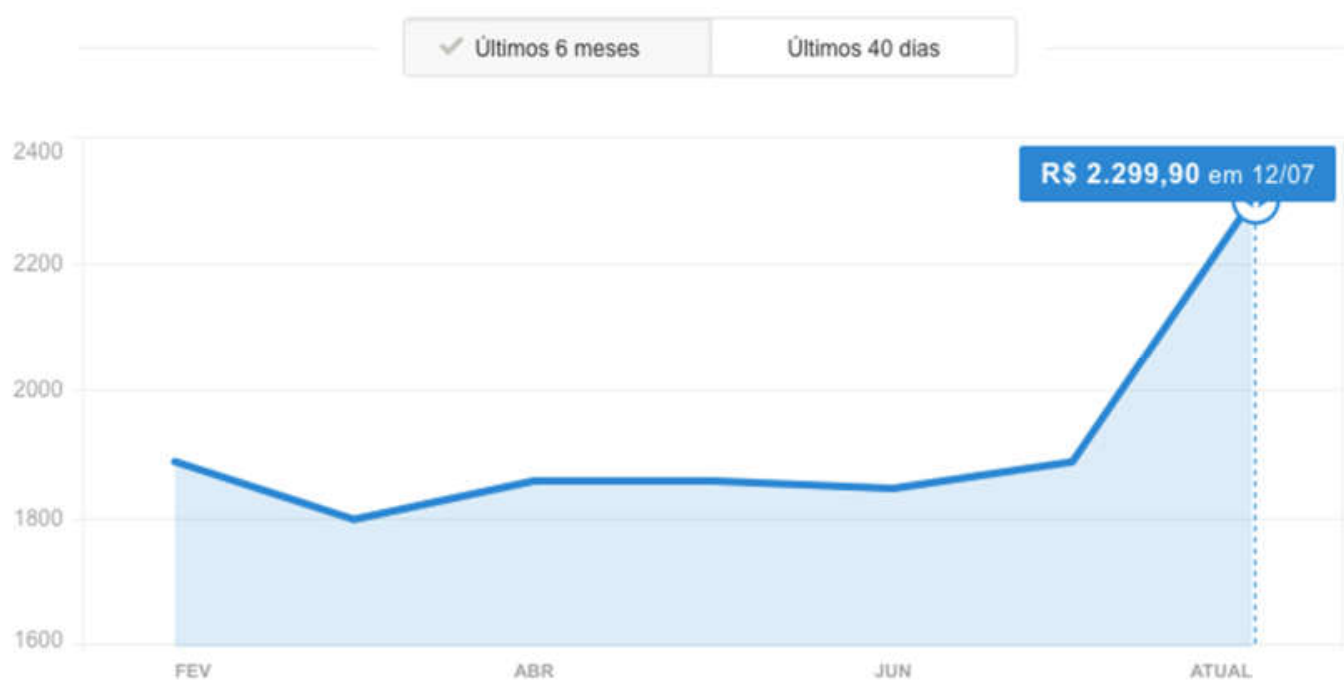

Fonte: Retirado do site Zoom.

\subsubsection{Vendas de Playstation 4}

Nesta seção apresentam-se as estatísticas descritivas das vendas de Playstation 4. No total foram registradas 10.360 transações.

A Tabela 20 mostra que, em comparação com as vendas de iPhones, há uma menor participação das vendas originadas de anúncios gratuitos (5\%) e um aumento nas realizadas através de anúncios pagos mais caros, do tipo Premium (42\%). Outros elementos que apresentaram diferença foram o percentual de vendas com frete gratuito para o comprador $(22 \%$ do videogame em comparação com os $66 \%$ do celular) e a garantia oferecida por parte do vendedor ( $89 \%$ das vendas do videogame e $67 \%$ do celular). Um percentual menor das vendas deixou explícito que o item era enviado com nota fiscal $(7,9 \%)$.

\footnotetext{
${ }^{8}$ http://www.magazineluiza.com.br/iphone-6-apple-16gb-cinza-espacial-tela-4.7-retina-4g-camera-8mp-frontalios-10-proc.-m8/p/2139815/te/ipho/

${ }^{9}$ https://www.zoom.com.br/celular/smartphone-apple-iphone-6-16gb-4g
} 
Tabela 20 - Características dos anúncios nas vendas de Playstation 4

\begin{tabular}{|c|c|c|c|c|c|c|}
\hline \multirow{2}{*}{$\begin{array}{l}\text { TIPODO- } \\
\text { ANUNCIO }\end{array}$} & Gratuito & Gra. \% & Clássico & Cl. \% & Premium & Prem. \% \\
\hline & 523 & 0,05 & 5582 & 0,539 & 4255 & 0,410 \\
\hline \multirow[t]{2}{*}{ VIDEO } & Sim & \multicolumn{2}{|c|}{$\operatorname{Sim} \%$} & Não & \multicolumn{2}{|c|}{ Não \% } \\
\hline & 1078 & \multicolumn{2}{|c|}{0,104} & 9282 & \multicolumn{2}{|c|}{0,896} \\
\hline \multirow{2}{*}{$\begin{array}{c}\text { MERCADO- } \\
\text { ENVIOS }\end{array}$} & Sim & \multicolumn{2}{|c|}{$\operatorname{Sim} \%$} & Não & \multicolumn{2}{|c|}{ Não \% } \\
\hline & 10306 & \multicolumn{2}{|c|}{0,995} & 54 & \multicolumn{2}{|c|}{0,005} \\
\hline \multirow{2}{*}{$\begin{array}{c}\text { FRETE- } \\
\text { GRATUITO }\end{array}$} & Sim & \multicolumn{2}{|c|}{$\operatorname{Sim} \%$} & Não & \multicolumn{2}{|c|}{ Não \% } \\
\hline & 2267 & \multicolumn{2}{|c|}{0,219} & 8093 & \multicolumn{2}{|c|}{0,781} \\
\hline \multirow[t]{2}{*}{ GARANTIA } & Sim & \multicolumn{2}{|c|}{$\operatorname{Sim} \%$} & Não & \multicolumn{2}{|c|}{ Não \% } \\
\hline & 9246 & \multicolumn{2}{|c|}{0,893} & 1114 & \multicolumn{2}{|c|}{0,107} \\
\hline \multirow{2}{*}{$\begin{array}{l}\text { IDADEDO- } \\
\text { ANUNCIO }\end{array}$} & Mínimo & Prim. Quad. & Mediana & Média & Terc. Quad. & Máximo \\
\hline & 0 & 49 & 125 & 202,7 & 397 & 576 \\
\hline \multirow[t]{2}{*}{ QTDFOTOS } & Mínimo & Prim. Quad. & Mediana & Média & Terc. Quad. & Máximo \\
\hline & 0 & 3 & 4 & 4,15 & 5 & 9 \\
\hline \multirow[t]{2}{*}{ EMITENF } & Sim & \multicolumn{2}{|c|}{ Sim \% } & Não & \multicolumn{2}{|c|}{ Não \% } \\
\hline & 822 & \multicolumn{2}{|c|}{0,079} & 953 & \multicolumn{2}{|c|}{0,921} \\
\hline
\end{tabular}

Fonte: Elaborado pelo autor

Nas vendas de videogame há alguns indícios da presença de vendedores grandes, que negociaram muitas unidades no período. Por exemplo, na Tabela 21 obseva-se que há um grande volume de vendas realizadas por vendedores MercadoLíder Platinum (73,7\%), a mediana de transações completas anteriores dos vendedores é alta (9861) e a média ainda maior (15260). Este ponto será explorado mais profundamente mais adiante.

Tabela 21 - Características dos vendedores nas vendas de Playstation 4

\begin{tabular}{|c|c|c|c|c|}
\hline \multirow{2}{*}{ NACAPITAL } & Capital & Capital \% & Interior & Interior \% \\
\cline { 2 - 5 } & 2283 & 0,220 & 8077 & 0,780 \\
\hline \multirow{2}{*}{$\begin{array}{c}\text { LOJA- } \\
\text { OFICIAL }\end{array}$} & Sim & Sim \% & Não & Não \% \\
\cline { 2 - 5 } & 4 & 0,000 & 10356 & 1,000 \\
\hline
\end{tabular}




\begin{tabular}{|c|c|c|c|c|c|c|c|c|c|c|c|}
\hline \multirow{4}{*}{\begin{tabular}{|c} 
IDADE- \\
VENDEDOR
\end{tabular}} & \multirow{2}{*}{\multicolumn{2}{|c|}{ Mínimo }} & \multicolumn{2}{|c|}{ Prim. Quad. } & Mediana & Média & \multicolumn{3}{|c|}{ Terc. Quad. } & \multicolumn{2}{|c|}{ Máximo } \\
\hline & & & \multicolumn{2}{|c|}{858} & 1468 & 1711 & \multicolumn{3}{|c|}{2301} & \multicolumn{2}{|c|}{6213} \\
\hline & \multirow[t]{2}{*}{ Nenhum } & \multirow[t]{2}{*}{ N. \% } & \multirow[t]{2}{*}{ Verm. } & \multirow[t]{2}{*}{ V. \% } & \multirow[t]{2}{*}{ Lar. L. \% } & \multirow[t]{2}{*}{ Amar. } & \multicolumn{3}{|c|}{ A. \%Verde V.C. } & Verde & V.E. \\
\hline & & & & & & & & Clarc & $\%$ & Escuro & $\%$ \\
\hline & 158 & 0,015 & 3 & 0,000 & \begin{tabular}{l|l}
15 & 0,001
\end{tabular} & 107 & 0,010 & 272 & 0,026 & 9805 & 0,946 \\
\hline QTDVENDA- & \multicolumn{2}{|c|}{ Mínimo } & \multicolumn{2}{|c|}{ Prim. Quad. } & Mediana & Média & \multicolumn{3}{|c|}{ Terc. Quad. } & \multicolumn{2}{|c|}{ Máximo } \\
\hline ANUN & \multicolumn{2}{|l|}{0} & \multicolumn{2}{|c|}{16} & 108 & 343,6 & \multicolumn{3}{|c|}{356} & \multicolumn{2}{|c|}{4261} \\
\hline MERCADO- & \multicolumn{2}{|c|}{ Nenhum } & N. \% & Silver & S. $\%$ & Gold & G. $\%$ & \multicolumn{2}{|c|}{ Platinum } & \multicolumn{2}{|c|}{ P. \% } \\
\hline LIDER & \multicolumn{2}{|c|}{1767} & 0,170 & 249 & 0,024 & 699 & 0,067 & \multicolumn{2}{|c|}{7645} & \multicolumn{2}{|c|}{0,738} \\
\hline TRANSA- & \multicolumn{2}{|c|}{ Mínimo } & \multicolumn{2}{|c|}{ Prim. Quad. } & Mediana & Média & Ter & rc. Qt & uad. & Máx & imo \\
\hline $\begin{array}{c}\text { ÇÕESCOM- } \\
\text { PLETAS }\end{array}$ & 0 & & 15 & 67 & 9861 & 15260 & & 16800 & & 1447 & 700 \\
\hline PERCENT- & Mínir & & Prim. & Quad. & Mediana & Média & Ter & rc. Qt & lad. & Máx & imo \\
\hline NEGATIVO & 0 & & & 0 & 0,01 & 0,096 & & 0,01 & & 1 & \\
\hline
\end{tabular}

Fonte: Elaborado pelo autor.

Os preços praticados nas vendas do videogame apresentaram uma amplitude de valores ainda maior que a ocorrida nas vendas dos celulares, variando de $\mathrm{R} \$ 500,00$ até $\mathrm{R} \$ 2.500,00$, mas um desvio padrão um pouco menor $(\mathrm{R} \$ 176,11)$, conforme apresentado na Tabela 22. A mediana $(\mathrm{R} \$ 1.389,90)$ possui valor próximo a média $(\mathrm{R} \$ 1404,95)$ e da moda $(\mathrm{R} \$ 1399,99)$.

Tabela 22 - Variação de preços nas vendas de iPhones

\begin{tabular}{|c|c|c|c|c|c|c|}
\hline \multirow{2}{*}{ Preço } & Mínimo & Prim. Quad. & Mediana & Média & Terc. Quad. & Máximo \\
\cline { 2 - 7 } & 500 & 1290 & 1390 & 1404,95 & 1499 & 2500 \\
\hline
\end{tabular}

Fonte: Elaborado pelo autor.

A Figura 20 apresenta uma distribuição de frequência dos valores. Diferente do que foi visto nas vendas de iPhone, a distribuição aqui apresenta uma assimetria positiva $(1,15)$. Foi observado, consultando o conteúdo dos anúncios que, entre as vendas de maior valor, é comum a presença de brindes, jogos ou controles adicionais. Estes videogames são vendidos, por padrão, com apenas um controle. Uma estratégia adotada por alguns vendedores é a inclusão de um controle extra na venda. 
Figura 20 - Distribuição de frequência para os preços das vendas de PS4

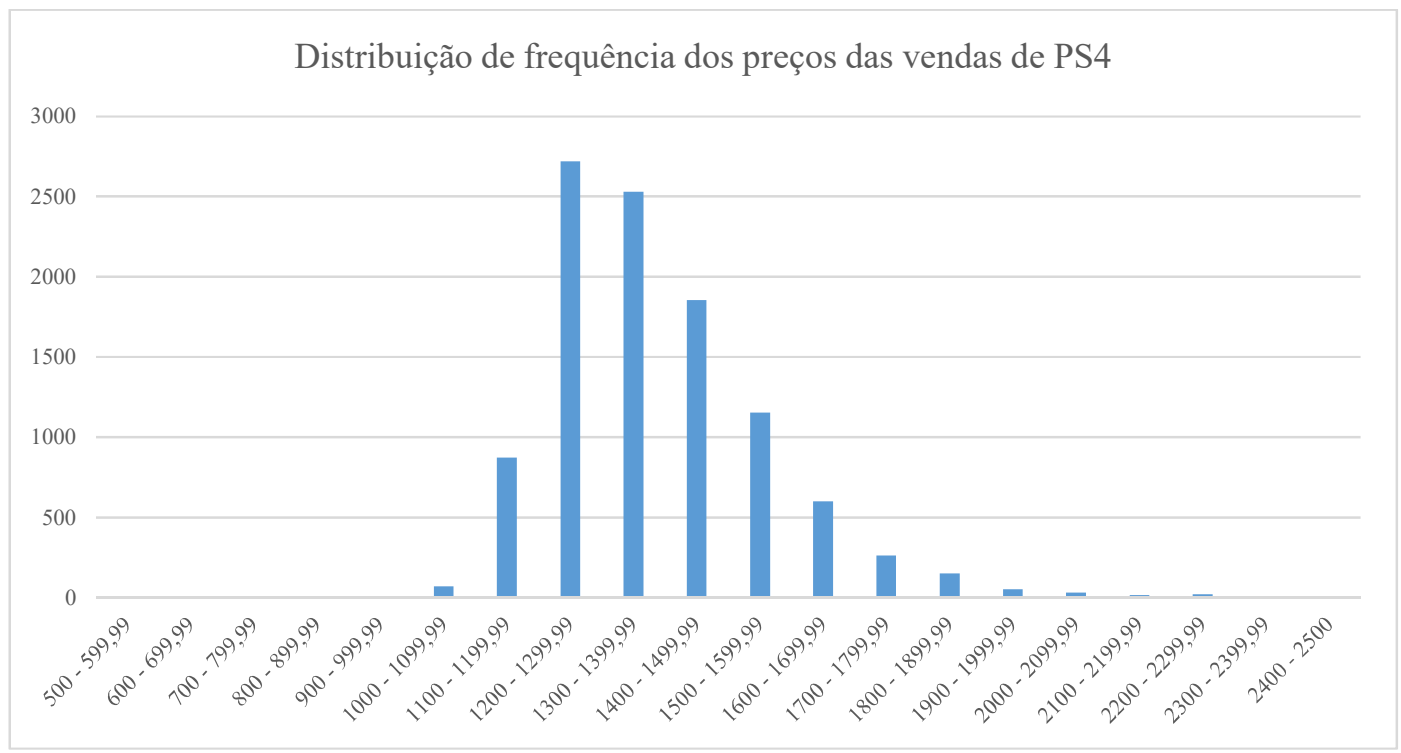

Fonte: Elaborado pelo autor.

No total, foram efetuadas 1631 vendas $(15,72 \%)$ de videogames com dois controles. Nas lojas, um controle adicional custa cerca de $\mathrm{R} \$ 200,00$. Foi constatado que estas vendas com mais de um controle possuem um valor maior, como pode ser observado na Figura 21. Por este motivo, esta variável foi incluída no modelo para as vendas de Playstation 4 e apresentado no detalhamento da Tabela 23.

Figura 21 - Valores das vendas de PS4 com um controle ou dois controles

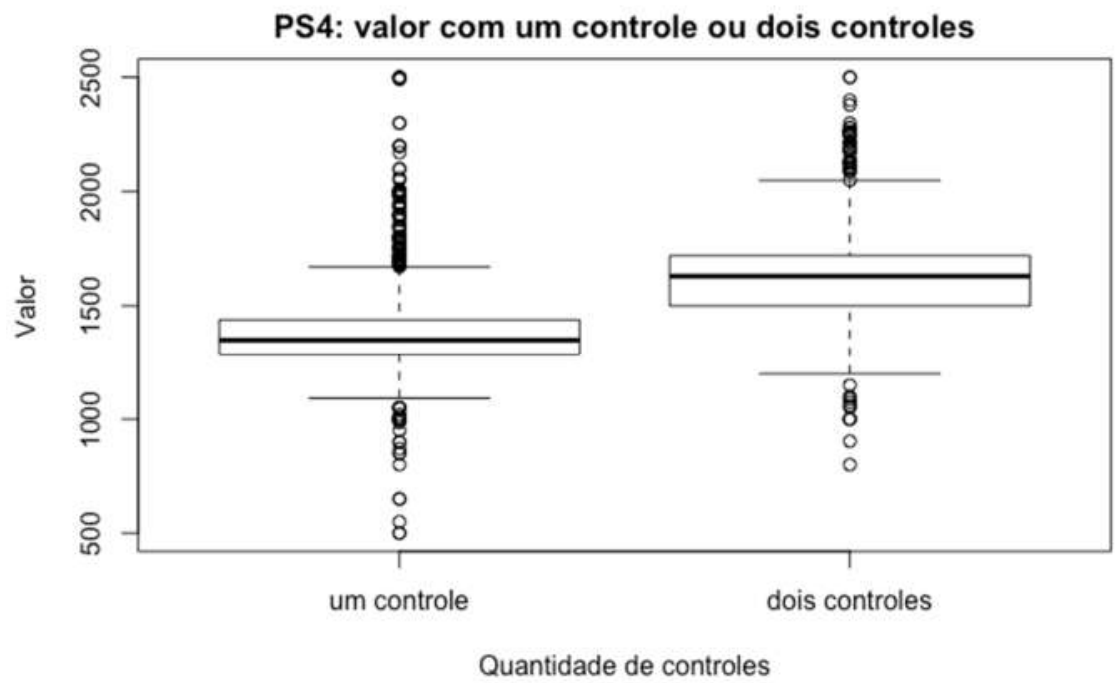

Fonte: Elaborado pelo autor. 
Tabela 23 - Características do produto nas vendas de Playstation 4

\begin{tabular}{|c|c|c|c|c|}
\hline \multirow{2}{*}{ NACAIXA } & Sim & Sim \% & Não & Não \% \\
\cline { 2 - 5 } & 1889 & 0,182 & 8471 & 0,818 \\
\hline \multirow{2}{*}{$\begin{array}{c}\text { ESTADO- } \\
\text { ITEM }\end{array}$} & Novo & Novo \% & Usado & Usado \% \\
\cline { 2 - 5 } DOISCON- & 9863 & 0,952 & 497 & 0,048 \\
\cline { 2 - 5 } TROLES & Sim & Sim \% & Não & Não \% \\
\hline
\end{tabular}

Assim como ocorreu com as vendas de iPhone, as vendas de Playstation 4 apresentaram preços em geral inferiores aos oferecidos no varejo "não-marketplace", sendo vendidos em média por $\mathrm{R} \$ 1.404,95$. O preço oficial divulgado pela Sony para o videogame PS4 na versão Slim de $500 \mathrm{gb}$ é $\mathrm{R} \$ 2.399,90^{10}$ mas ele pode ser facilmente encontrado por valores bem menores. No site do MagazineLuiza o videogame está anunciado por $\mathrm{R} \$ 1.899,00^{11}$ e no comparador de preços Zoom o menor valor ofertado atualmente é de $\mathrm{R} \$ 1.419,99$ (Figura 22). Nos últimos seis meses, o site chegou a registrar uma oferta o videogame sendo vendido por até $\mathrm{R} \$ 1.117,66$.

Figura 22 - Variação do preço ofertado de Playstation 4 nas lojas virtuais tradicionais

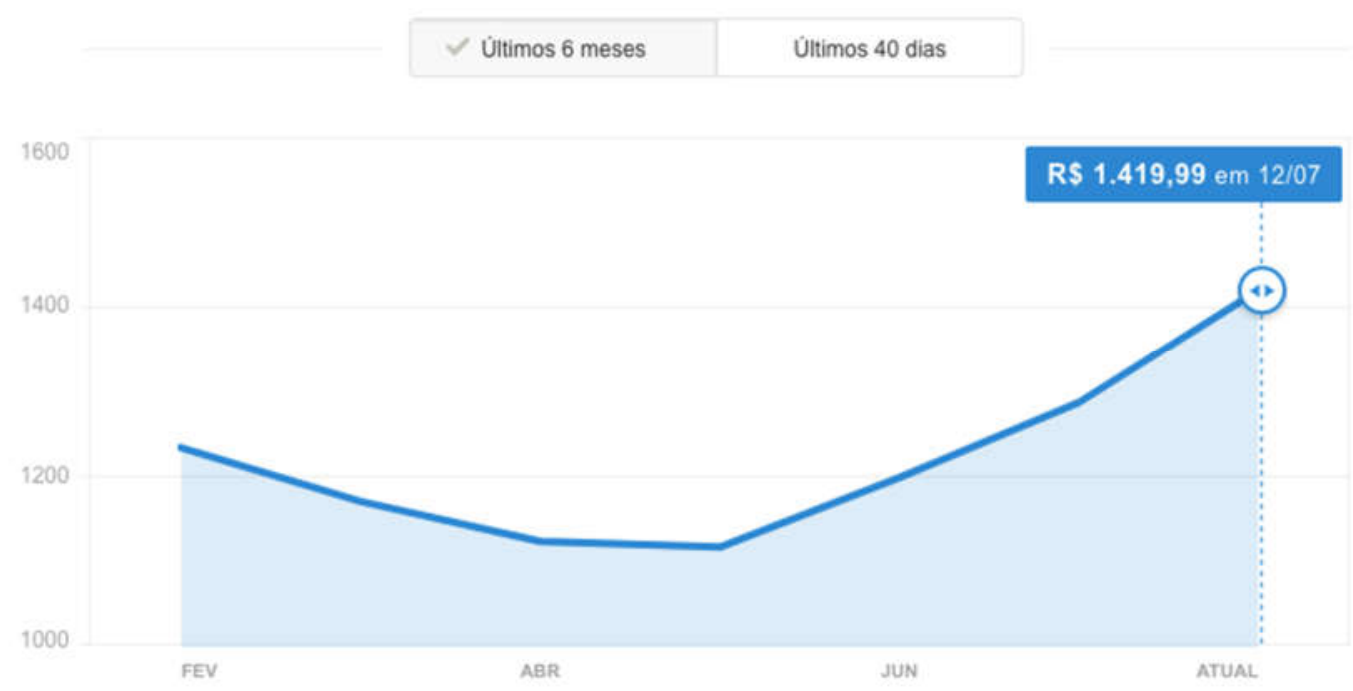

Fonte: Retirado do site Zoom.

\footnotetext{
${ }^{10} \mathrm{http}: / /$ games.tecmundo.com.br/noticias/ps4-slim-chega-brasil-preco-sugerido-r-2399_826462.htm

${ }^{11} \mathrm{http}$ //www.magazineluiza.com.br/playstation-4-slim-500gb-sony-1-controle-jogo-uncharted-4-nacional-com1-ano-de-garantia/p/0430755/ga/gps4/
} 


\subsubsection{Vendas de Tênis}

Com 849 unidades vendidas, os tênis femininos Osklen foram os produtos com menor quantidade de transações realizadas no período. Como observa-se na Tabela 24, diferente do que ocorreu nos anteriores, para este produto não ocorreram vendas em anúncios gratuitos. Também não ocorreram vendas a partir de anúncios com vídeo, mas os anúncios que realizaram vendas continham proporcionalmente mais fotos que nos outros produtos (mediana de 6 fotos).

Tabela 24 - Características do produto nas vendas de Tênis

\begin{tabular}{|c|c|c|c|c|c|c|}
\hline \multirow{2}{*}{$\begin{array}{l}\text { TIPODO- } \\
\text { ANUNCIO }\end{array}$} & Gratuito & Gra. \% & Clássico & Cl. \% & Premium & Prem. \% \\
\hline & 0 & 0,00 & 610 & 0,718 & 239 & 0,282 \\
\hline VIDEO & \multicolumn{2}{|c|}{ Sim } & Sim \% & Não & \multicolumn{2}{|c|}{ Não \% } \\
\hline & \multicolumn{2}{|l|}{0} & 0,000 & 849 & \multicolumn{2}{|c|}{1,000} \\
\hline MERCADO- & \multicolumn{2}{|c|}{ Sim } & Sim \% & Não & \multicolumn{2}{|c|}{ Não \% } \\
\hline ENVIOS & \multicolumn{2}{|c|}{849} & 1,000 & 0 & \multicolumn{2}{|c|}{0,000} \\
\hline FRETE- & \multicolumn{2}{|c|}{ Sim } & Sim \% & Não & \multicolumn{2}{|c|}{ Não \% } \\
\hline GRATUITO & \multicolumn{2}{|c|}{405} & 0,477 & 444 & \multicolumn{2}{|c|}{0,523} \\
\hline \multirow[t]{2}{*}{ GARANTIA } & \multicolumn{2}{|c|}{ Sim } & Sim \% & Não & \multicolumn{2}{|c|}{ Não \% } \\
\hline & 731 & & 0,861 & 118 & \multicolumn{2}{|c|}{0,139} \\
\hline \multirow{2}{*}{$\begin{array}{l}\text { IDADEDO- } \\
\text { ANUNCIO }\end{array}$} & Mínimo & Prim. Quad. & Mediana & Média & Terc. Quad. & Máximo \\
\hline & 1 & 194 & 374 & 353,9 & 517 & 587 \\
\hline QTDFOTOS & Mínimo & Prim. Quad. & Mediana & Média & Terc. Quad. & Máximo \\
\hline & 1 & 4 & 6 & 11,42 & 10 & 87 \\
\hline EMITENF & Sim & & im $\%$ & Nã & & \\
\hline & 63 & &, 074 & 78 & & \\
\hline
\end{tabular}

Fonte: Elaborado pelo autor.

A Tabela 25 mostra uma grande participação de vendas realizadas por vendedores no interior, possivelmente devido aos clusters calçadistas destas regiões. Apesar de existirem vendedores experientes, com contas criadas há mais de 13 anos (4821 dias), os vendedores são em geral menos experientes que os de iPhone ou PS4. Considerando o termômetro, os usuários que 
realizaram vendas possuem em geral uma reputação um pouco melhor que a dos vendedores de iPhone mas pior que a dos que trabalham com o videogame.

Tabela 25 - Características do vendedor nas vendas de Tênis

\begin{tabular}{|c|c|c|c|c|c|c|c|c|c|c|}
\hline \multirow[t]{2}{*}{ NACAPITAL } & \multicolumn{2}{|l|}{ Capital } & \multicolumn{2}{|c|}{ Capital \% } & \multicolumn{2}{|c|}{ Interior } & \multicolumn{4}{|c|}{ Interior \% } \\
\hline & \multicolumn{2}{|l|}{18} & \multicolumn{2}{|c|}{0,021} & \multicolumn{2}{|c|}{831} & \multicolumn{4}{|c|}{0,979} \\
\hline LOJA- & \multicolumn{2}{|l|}{ Sim } & \multicolumn{2}{|c|}{ Sim \% } & \multicolumn{2}{|c|}{ Não } & \multicolumn{4}{|c|}{ Não \% } \\
\hline OFICIAL & \multicolumn{2}{|l|}{0} & \multicolumn{2}{|c|}{0,000} & \multicolumn{2}{|c|}{849} & \multicolumn{4}{|c|}{1,000} \\
\hline IDADE- & Mínimo & \multicolumn{2}{|c|}{ Prim. Quad. } & Mediana & Média & \multicolumn{3}{|c|}{ Terc. Quad. } & \multicolumn{2}{|c|}{ Máximo } \\
\hline VENDEDOR & 78 & \multicolumn{2}{|c|}{664} & 1140 & 1331 & \multicolumn{3}{|c|}{1836} & \multicolumn{2}{|c|}{4821} \\
\hline \multirow[t]{2}{*}{$\begin{array}{l}\text { TERMO- } \\
\text { METRO }\end{array}$} & Nenhum N. \% & Verm. & V.\% & Lar. L. \% & Amar. & A. \% & $\begin{array}{l}\text { Verde } \\
\text { Claro }\end{array}$ & $\begin{array}{c}\text { V.C. } \\
\%\end{array}$ & $\begin{array}{l}\text { Verde } \\
\text { Escuro }\end{array}$ & $\begin{array}{c}\text { V.E. } \\
\%\end{array}$ \\
\hline & $2 \quad 0,002$ & 0 & 0,000 & \begin{tabular}{l|l|}
0 & 0,000
\end{tabular} & 3 & 0,004 & 97 & 0,114 & 9821 & 0,880 \\
\hline \multirow{2}{*}{$\begin{array}{c}\text { QTDVENDA- } \\
\text { ANUN }\end{array}$} & Mínimo & \multicolumn{2}{|c|}{ Prim. Quad. } & Mediana & Média & \multicolumn{3}{|c|}{ Terc. Quad. } & \multicolumn{2}{|c|}{ Máximo } \\
\hline & 0 & \multicolumn{2}{|c|}{16} & 107 & 343,5 & & 355 & & 426 & \\
\hline MERCADO- & Nenhum & N. $\%$ & Silver & S. $\%$ & Gold & G. $\%$ & Plat & tinum & P. ${ }^{\circ}$ & \\
\hline LIDER & 362 & 0,426 & 61 & 0,072 & 180 & 0,212 & & 246 & 0,29 & \\
\hline TRANSA- & Mínimo & Prim. & Quad. & Mediana & Média & Ter & c. Qua & ad. & Máxi & imo \\
\hline $\begin{array}{c}\text { ÇÕESCOM- } \\
\text { PLETAS }\end{array}$ & 0 & 11 & 25 & 6255 & 13500 & & 19570 & & 577 & \\
\hline PERCENT- & Mínimo & Prim. & Quad. & Mediana & Média & Ter & c. $Q u$ & ad. & Máxi & imo \\
\hline NEGATIVO & 0 & 0,0 & 10 & 0,010 & 0,013 & & 0,010 & & 1 & \\
\hline
\end{tabular}

Fonte: Elaborado pelo autor.

Os preços das vendas variaram de $\mathrm{R} \$ 59,90$ até $\mathrm{R} \$ 200,00$, apresentando uma média de $\mathrm{R} \$ 110,82$, mediana de $\mathrm{R} \$ 99,99$ e desvio padrão de $\mathrm{R} \$ 27,86$.

Tabela 26 - Variação de preços nas vendas de Playstation 4

\begin{tabular}{|c|c|c|c|c|c|c|}
\hline \multirow{2}{*}{ Preço } & Mínimo & Prim. Quad. & Mediana & Média & Terc. Quad. & Máximo \\
\cline { 2 - 7 } & 59,90 & 92,51 & 99,99 & 110,82 & 129,82 & 200 \\
\hline
\end{tabular}

Fonte: Elaborado pelo autor. 
A Figura 23 mostra a distribuição de preços das vendas de tênis.

Figura 23 - Distribuição de frequência para os preços das vendas de tênis

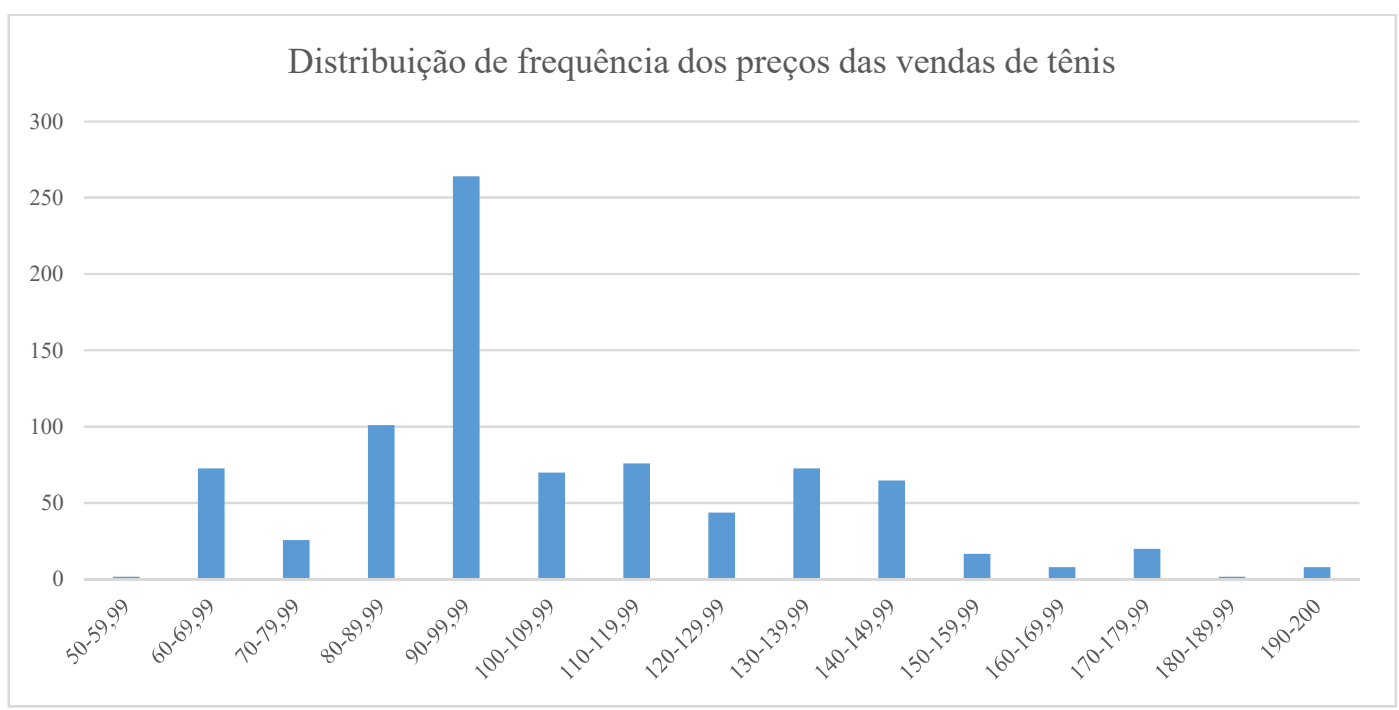

Fonte: Elaborado pelo autor.

Neste trabalho optou-se por não considerar as vendas de tênis usados pois, além do pequeno volume de transações há uma enorme variação de modelos e estados. Conforme exposto na Tabela 27, todas as 849 vendas foram de itens novos e a maioria não deixava explícito que o envio era feito na caixa original.

Tabela 27 - Características do produto nas vendas de Tênis

\begin{tabular}{|c|c|c|c|c|}
\hline \multirow{2}{*}{ NACAIXA } & Sim & Sim \% & Não & Não \% \\
\cline { 2 - 5 } & 150 & 0,177 & 699 & 0,823 \\
\hline \multirow{2}{*}{\begin{tabular}{c} 
ITEMADO- \\
\cline { 2 - 5 }
\end{tabular}} & Novo & Novo \% & Usado & Usado \% \\
\hline
\end{tabular}

Fonte: Elaborado pelo autor.

Os preços praticados na loja oficial da marca Osklen variam bastante de acordo com o modelo, mas são bem superiores aos que foram registrados no Mercado Livre (o modelo mais barato exibido no site da marca custa $\mathrm{R} \$ 247,00$ e o mais caro $\mathrm{R} \$ 1.247,00)^{12}$.

\footnotetext{
${ }^{12} \mathrm{http}$ ://store.osklen.com/shoes?PS=16\&O=OrderByPriceDESC
} 


\subsubsection{Anúncios}

Um vendedor que deseje vender mais de uma unidade de um mesmo produto não precisa criar vários anúncios semelhantes. Em uma mesma publicação ele pode informar quantas unidades

possui em estoque. É possível, inclusive, atualizar esta quantidade, para mais ou para menos, a qualquer momento. O Mercado Livre mantém o anúncio disponível por sessenta dias ou até todas as unidades serem vendidas, dependendo do tipo de anúncio contratado (gratuito, clássico ou premium).

No total, as 12.938 vendas foram realizadas através de 2.106 anúncios, em uma média de 6,14 vendas por anúncio. Este número de vendas por anúncio varia de acordo com o produto. No caso dos iPhones, há um volume maior de anúncios de itens únicos, que realizam apenas uma venda e fazem com que a média de vendas por anúncio seja menor. As 1729 vendas de iPhones foram realizadas através de 614 anúncios diferentes, com uma média de apenas 2,81 vendas por anúncio. Observa-se ainda a existência de 480 anúncios, ou seja, 78\% do total de anúncios, que realizaram apenas uma venda.

No outro extremo estão as vendas de Playstation 4, cujas 10.360 vendas foram realizadas por 1.299 anúncios, em uma média de 7,98 vendas por anúncio. O principal motivo desta média ser elevada é a presença de um pequeno conjunto de anúncios que realiza um grande número de vendas. Apesar de existirem 716 anúncios (55\% do total) que realizaram apenas uma venda, há também um grupo de 19 anúncios com mais de 100 vendas cada.

A Figura 24 mostra a distribuição de anúncios de iPhone de acordo com a quantidade de vendas realizadas e a Figura 25 apresenta estas informações referentes as vendas de Playstation 4.

Figura 24 - Distribuição de anúncios de iPhone pela quantidade de vendas realizadas 


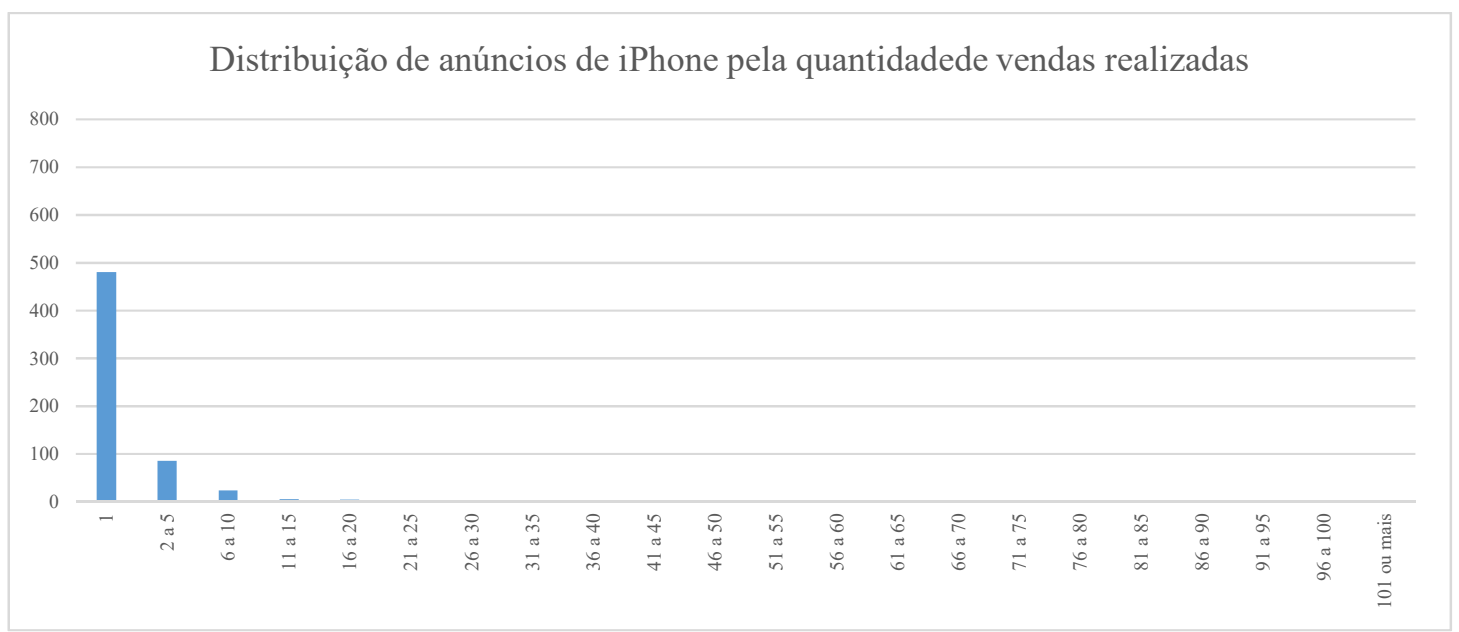

Fonte: Elaborado pelo autor.

Figura 25 - Distribuição de anúncios de PS4 pela quantidade de vendas realizadas

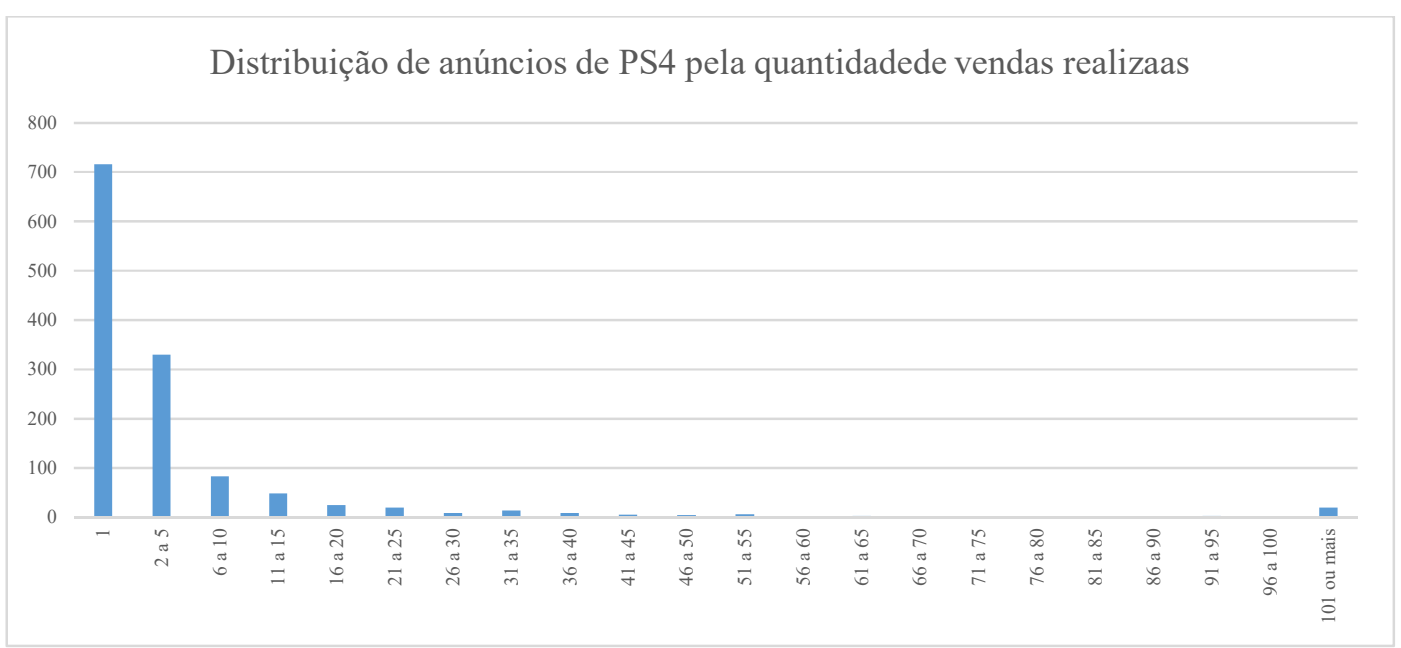

Fonte: Elaborado pelo autor.

Os anúncios de tênis possuem uma média de vendas superior aos de iPhone mas inferior aos de Playstation 4. As 849 vendas de tênis foram realizadas por 193 anúncios, com uma média de 4,40 vendas por anúncio.

A Figura 26 apresenta a distribuição dos anúncios de acordo com a quantidade de vendas realizadas por eles durante o período analisado. 
Figura 26 - Distribuição de anúncios de tênis pela quantidade de vendas realizadas

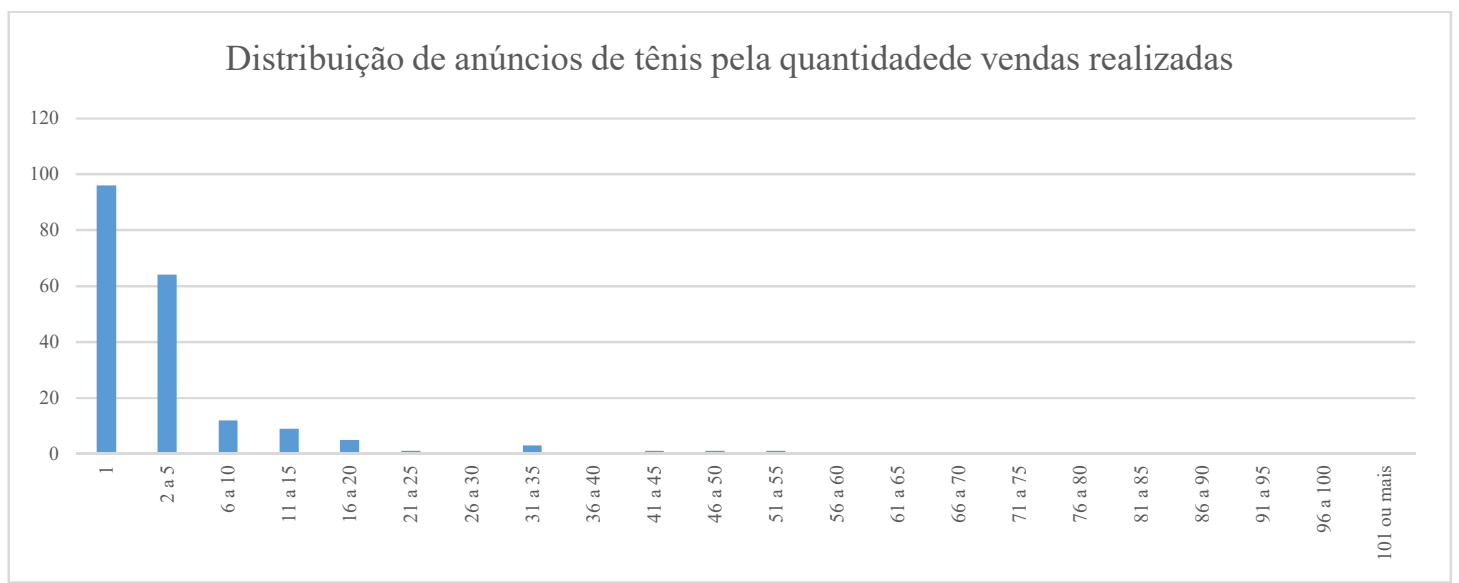

Fonte: Elaborado pelo autor.

Uma possível explicação para esta diferença seria existência de mais vendedores profissionais nos anúncios de Playstation que entre os anúncios de iPhone. Ou seja, no caso do videogame existem proporcionalmente menos vendedores, mas cada um possui um grande estoque. Já para o celular, há um grande número de vendedores pequenos, talvez pessoas físicas, vendendo um único aparelho. Novamente, as vendas de tênis apresentam um cenário intermediário. Não há anúncios com um grande volume de vendas, mas há proporcionalmente menos anúncios que realizaram apenas uma venda $(50 \%$ dos anúncios de tênis realizaram apenas uma venda, número mais próximo dos 55\% observados entre os de Playstation 4 que dos $78 \%$ referentes aos anúncios de iPhone). Isto pode indicar que, entre os anúncios de tênis há uma concentração de vendedores profissionais, mas estes não são tão grandes quanto os que trabalham com Playstation 4.

Estas conjecturas sobre o motivo da concentração de vendas em alguns anúncios estarem relacionadas ao porte do vendedor ganhariam mais força se cada vendedor publicasse apenas um anúncio concentrando todos os seus itens disponíveis, mas este não é o caso.

É oficialmente permitida a publicação de anúncios similares pelo mesmo vendedor no Mercado Livre apenas se estes apresentarem variações, como por exemplo uma versão com frete gratuito e outra com frete pago ou uma versão do anúncio na modalidade gratuita e outra com exposição adicional. É o caso, por exemplo, do vendedor BLACKSTOREBRASIL, que publicou um anúncio de iPhone com identificação “MLB788861379” por R\$2299,89 do tipo Premium e um 
anúncio similar por "MLB788864199” no valor de R $\$ 1999,90$ do tipo Clássico, chegando a realizar duas vendas do primeiro e uma do segundo no dia 12 de março de 2017.

Menos anúncios duplicados facilita a busca realizada pelos compradores, que conseguem visualizar todas as opções navegando em um menor conjunto de anúncios. Mas, por questões estratégicas, alguns vendedores preferem publicar vários anúncios similares ao mesmo tempo, mesmo que isto não respeite a política da plataforma e os deixem sujeitos a alguma punição. Um vendedor pode adotar esta prática, por exemplo, para tentar poluir o resultado das buscas, fazendo com que seus anúncios apareçam mais vezes que o dos concorrentes. Este é o caso, por exemplo, do vendedor AMERICANAELETRO, que publicou vários anúncios similares e que no dia 22 de fevereiro de 2017 realizou vendas tanto com o anúncio de código "MLB835507805" intitulado "Apple Iphone 6 16gb Original Lacrado Caixa Novo Vitrine" quanto com o anúncio “MLB835513060” com o título "Celular Smartphone Apple Iphone 6 $16 \mathrm{gb}$ Novo Original Vitrine”, ambas no valor de R\$1799,99.

Há ainda vendedores que ofertam, ao mesmo tempo, anúncios do mesmo produto, mas com pequenas variações. É o caso de diversos vendedores de iPhone que criam um anúncio para cada cor do aparelho ou de vendedores de Playstation 4 que dão um jogo de brinde e criam diversos anúncios, cada um com um jogo diferente.

A Tabela 16 mostra a participação dos anúncios no total de vendas realizadas. A maioria das vendas de iPhone foi realizada por anúncios que venderam dez unidades ou menos (52\%), ocorrendo principalmente entre os anúncios que venderam apenas uma unidade (28\%). Quase todas as vendas de tênis $(94 \%)$ também foram realizadas por anúncios que venderam dez ou menos unidades, mas neste produto a maior representação nas vendas é dos anúncios que venderam de 2 a 5 pares (45\%). Já para o Playstation 4, os 19 anúncios que venderam mais de 100 unidades cada foram responsáveis por $36 \%$ das vendas. 
Tabela 28 - Participação dos anúncios no total de vendas

\begin{tabular}{|c|c|c|c|c|c|c|c|c|c|}
\hline \multirow{2}{*}{$\begin{array}{c}\text { Vendas } \\
\text { por } \\
\text { anúncio }\end{array}$} & \multicolumn{3}{|c|}{ iPhone } & \multicolumn{3}{|c|}{ PS4 } & \multicolumn{3}{|c|}{ Tenis } \\
\hline & $\begin{array}{c}\text { Anúncios } \\
\text { Distintos }\end{array}$ & \begin{tabular}{|l|} 
Vendas \\
\end{tabular} & \begin{tabular}{|c|} 
Vendas \\
$(\%)$
\end{tabular} & $\begin{array}{l}\text { Anúncios } \\
\text { Distintos }\end{array}$ & Vendas & $\begin{array}{c}\text { Vendas } \\
(\%)\end{array}$ & $\begin{array}{l}\text { Anúncios } \\
\text { Distintos }\end{array}$ & Vendas & $\begin{array}{c}\text { Vendas } \\
(\%)\end{array}$ \\
\hline 1 & 480 & 480 & $28 \%$ & 716 & 716 & $7 \%$ & 96 & 96 & $11 \%$ \\
\hline 2 a 5 & 85 & 242 & $14 \%$ & 330 & 931 & $9 \%$ & 64 & 178 & $21 \%$ \\
\hline 6 a 10 & 24 & 174 & $10 \%$ & 83 & 643 & $6 \%$ & 12 & 99 & $12 \%$ \\
\hline 11 a 15 & 6 & 75 & $4 \%$ & 48 & 595 & $6 \%$ & 9 & 113 & $13 \%$ \\
\hline 16 a 20 & 5 & 88 & $5 \%$ & 25 & 439 & $4 \%$ & 5 & 95 & $11 \%$ \\
\hline 21 a 25 & 1 & 24 & $1 \%$ & 19 & 434 & $4 \%$ & 1 & 25 & $3 \%$ \\
\hline 26 a 30 & 2 & 54 & $3 \%$ & 8 & 231 & $2 \%$ & 0 & 0 & $0 \%$ \\
\hline 31 a 35 & 2 & 65 & $4 \%$ & 14 & 461 & $4 \%$ & 3 & 99 & $12 \%$ \\
\hline 36 a 40 & 3 & 111 & $6 \%$ & 8 & 305 & $3 \%$ & 0 & 0 & $0 \%$ \\
\hline 41 a 45 & 1 & 41 & $2 \%$ & 5 & 218 & $2 \%$ & 1 & 44 & $5 \%$ \\
\hline 46 a 50 & 2 & 97 & $6 \%$ & 4 & 196 & $2 \%$ & 1 & 47 & $6 \%$ \\
\hline 51 a 55 & 0 & 0 & $0 \%$ & 6 & 316 & $3 \%$ & 1 & 53 & $6 \%$ \\
\hline 56 a 60 & 0 & 0 & $0 \%$ & 1 & 60 & $1 \%$ & 0 & 0 & $0 \%$ \\
\hline 61 a 65 & 0 & 0 & $0 \%$ & 3 & 189 & $2 \%$ & 0 & 0 & $0 \%$ \\
\hline 66 a 70 & 0 & 0 & $0 \%$ & 1 & 70 & $1 \%$ & 0 & 0 & $0 \%$ \\
\hline 71 a 75 & 0 & 0 & $0 \%$ & 0 & 0 & $0 \%$ & 0 & 0 & $0 \%$ \\
\hline 76 a 80 & 1 & 80 & $5 \%$ & 1 & 78 & $1 \%$ & 0 & 0 & $0 \%$ \\
\hline 81 a 85 & 0 & 0 & $0 \%$ & 2 & 166 & $2 \%$ & 0 & 0 & $0 \%$ \\
\hline 86 a 90 & 0 & 0 & $0 \%$ & 2 & 174 & $2 \%$ & 0 & 0 & $0 \%$ \\
\hline 91 a 95 & 1 & 95 & $5 \%$ & 3 & 277 & $3 \%$ & 0 & 0 & $0 \%$ \\
\hline $\begin{array}{c}96 \mathrm{a} \\
100\end{array}$ & 0 & 0 & $0 \%$ & 1 & 96 & $1 \%$ & 0 & 0 & $0 \%$ \\
\hline $\begin{array}{c}101 \text { ou } \\
\text { mais }\end{array}$ & 1 & 103 & $6 \%$ & 19 & 3765 & $36 \%$ & 0 & 0 & $0 \%$ \\
\hline Total & 614 & 1729 & $100 \%$ & 1299 & 10360 & $100 \%$ & 193 & 849 & $100 \%$ \\
\hline
\end{tabular}

Fonte: Elaborado pelo autor.

É importante destacar que, apesar de um mesmo anúncio representar várias vendas no banco de dados desta pesquisa, isto não significa linhas repetidas. As vendas, mesmo que realizadas a partir do mesmo anúncio, possuem características próprias, como a quantidade de vendas realizadas anteriormente pelo anúncio, número de transações completas do vendedor e idades do anúncio e do vendedor. Todas as outras características do anúncio (como tipo, preço, título, descrição etc.) também podem ser alteradas ao longo do tempo.

Toma-se por exemplo o anúncio com maior quantidade de vendas, entre todos os produtos, que é o de código MLB687445178 do produto PS4. Este anúncio foi publicado originalmente em agosto de 2015 e realizou vendas todos os dias ao longo dos 58 dias em que os dados foram 
coletados, em um total de 545 unidades vendidas no período ( $5 \%$ do total de vendas deste produto). Durante estes dias, no entanto, o anúncio apresentou cinco títulos diferentes e realizou vendas com 12 preços diferentes, variando de $\mathrm{R} \$ 1.148,99$ até $\mathrm{R} \$ 1.439,99$. O percentual de avaliações negativas do vendedor também variou apresentando valores entre $0 \%$ e $1 \%$ entre estas vendas e o número de transações completas do vendedor aumentou de 13.768 na primeira venda coletada até 17.745 na última.

Consolidar as vendas em um único anúncio, como fez este vendedor, também pode uma estratégia. Ao invés encerrar o anúncio e publicar outros quando desejar efetuar alguma alteração, alguns vendedores preferem manter a publicação original e apenas modificar seu conteúdo. Como o Mercado Livre exibe a quantidade de vendas já realizadas por cada anúncio na própria publicação, um anúncio com muitas transações anteriores pode passar maior credibilidade para os compradores e facilitar vendas.

Além disso, ao concentrar as vendas em um único anúncio é possível divulgar o link para a oferta em outros locais e conseguir mais visitas. Em uma busca no Google pelo código deste anúncio é possível encontrar postagens em dois fóruns relacionados ao tema (Clube do Hardware $^{13}$ e Fórum de Jogos do $\mathrm{UOL}^{14}$ ) que possuem um link direto para este anúncio.

\subsubsection{Vendedores}

Observando-se apenas os anúncios, na seção anterior foi introduzida uma discussão sobre o porte dos vendedores de cada produto. Ainda que a quantidade de vendas por anúncio não fosse suficiente para comprovar esta questão, ela é um indício de que haveria um grande número de vendedores esporádicos com uma única venda entre no caso dos iPhone, um maior número de grandes vendedores profissionais no caso dos Playstation 4 e a existência vendedores profissionais de menor porte trabalhando com a venda tênis.

Analisando-se a quantidade de usuários distintos que realizaram vendas no período, tem-se a confirmação destas hipóteses. No total, as 12.938 vendas foram realizadas por 1.069 vendedores, com uma média de 12,10 para cada. Esta média é bem inferior para os iPhones,

\footnotetext{
${ }^{13} \mathrm{http}$ //www.clubedohardware.com.br/forums/topic/1206212-pessoal-algum-de-voc\%C3\%AAs-conseguemencontrar-uma-oferta-de-ps4-melhor-que-essa/

${ }^{14} \mathrm{http}$ ://forum.jogos.uol.com.br/entrando-no-mundo-ps-nessa-geracao-comprar-no-ml-ou-nao_t_3938368
} 
sendo apenas 3,94 unidades por vendedor. Na Figura 27 é apresentada a distribuição dos vendedores de iPhone de acordo com a quantidade de vendas que cada um realizou no período. O gráfico segue padrão similar ao da Figura 24, inclusive apresentando apenas um vendedor com mais de 100 unidades vendidas e uma grande quantidade de anúncios ou vendedores com apenas uma transação. Os 614 anúncios foram postados por 439 vendedores, com uma média de 1,40 anúncios por vendedor.

Figura 27 - Distribuição de vendedores de iPhone pela quantidade de vendas realizadas

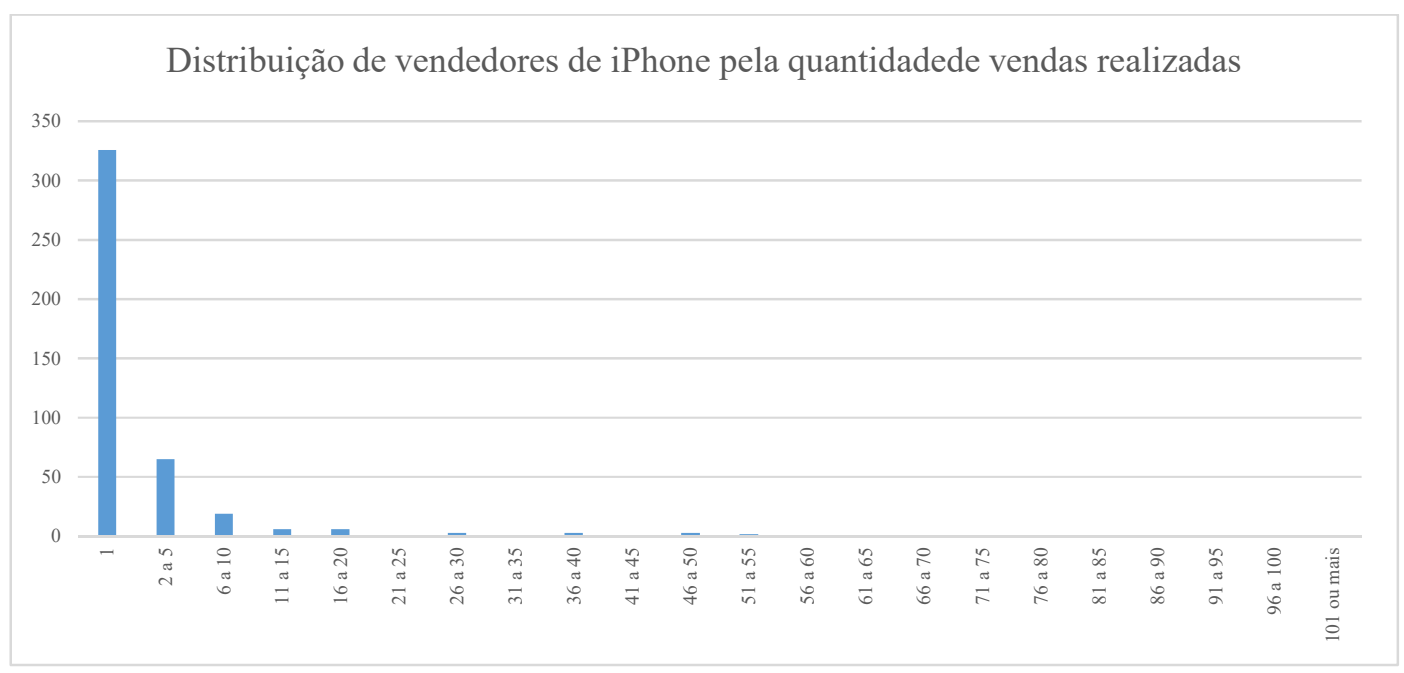

Fonte: Elaborado pelo autor.

Tanto os tênis quanto os Playstation 4 apresentam médias elevadas de vendas realizadas por usuário, sendo 18,05 e 15,16 respectivamente. Mas, para o videogame, observamos claramente na Figura 28 a existência de um grande número de vendedores (318) que fizeram apenas uma venda, seguindo por uma quantidade inferior de usuários com 2 a 5 unidades vendidas (128). Este número segue diminuindo a medida que a quantidade de transações realizadas aumenta, até chegar no grupo dos grandes vendedores com mais de 100 vendas e apresentar um salto para 25 vendedores.

Comparando este gráfico com aquele apresentado anteriormente na Figura 25, observa-se que apesar de existirem 716 anúncios que realizaram apenas uma venda, existem apenas 318 vendedores que venderam somente uma unidade. E apesar do primeiro gráfico mostrar apenas 19 anúncios com mais de cem vendas, há no segundo gráfico 25 vendedores que venderam mais que cem videogames. Isto indica que os vendedores de Playstation 4 adotam a prática de 
publicar mais de um anúncio do produto. Os 1299 anúncios foram publicados por 574 vendedores distintos (média de 2.26 anúncios por vendedor).

Figura 28- Distribuição de vendedores de PS4 pela quantidade de vendas realizadas

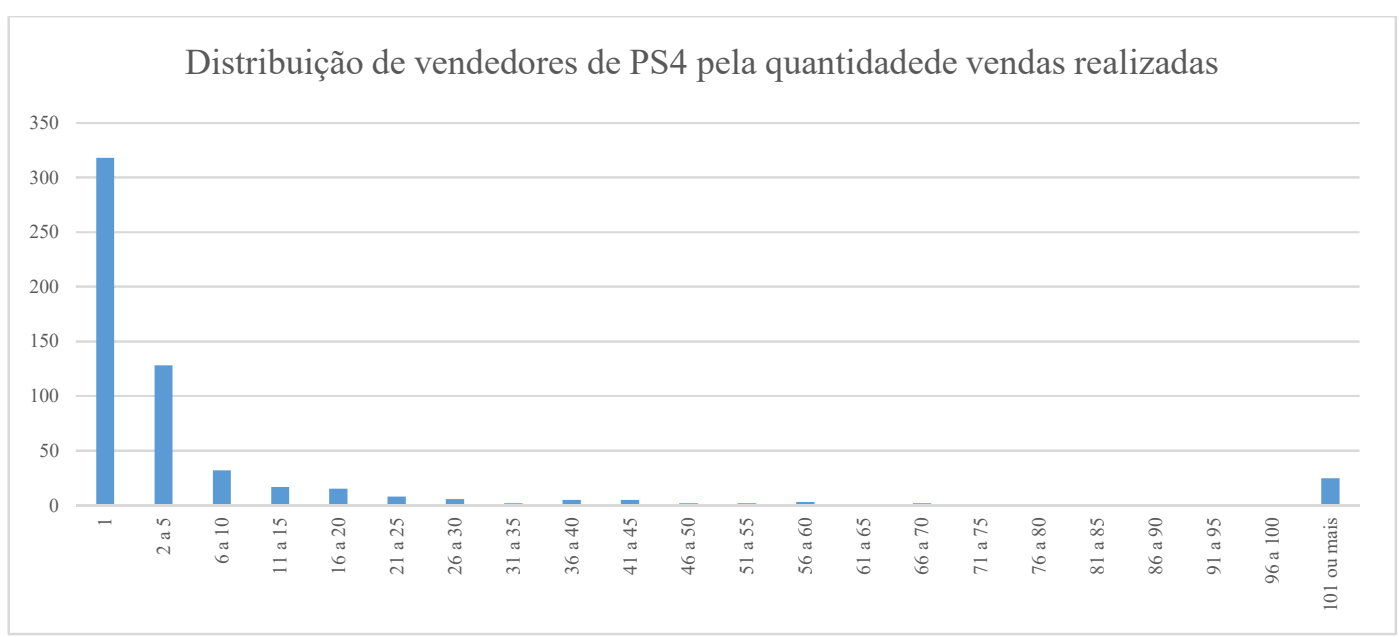

Fonte: Elaborado pelo autor.

Entre os vendedores de tênis, o número de usuários que realizaram apenas uma venda (15) é igual ao dos que realizaram 2 a 5 e há uma concentração em torno da faixa de 11 a 15 vendas, como pode ser observado na Figura 29. Isto é mais uma evidência que entre os vendedores de tênis há menos pessoas que vendem apenas uma unidade e há um grupo de vendedores de pequeno porte.

Figura 29 - Distribuiçào de vendedores de tênis pela quantidade de vendas relizadas

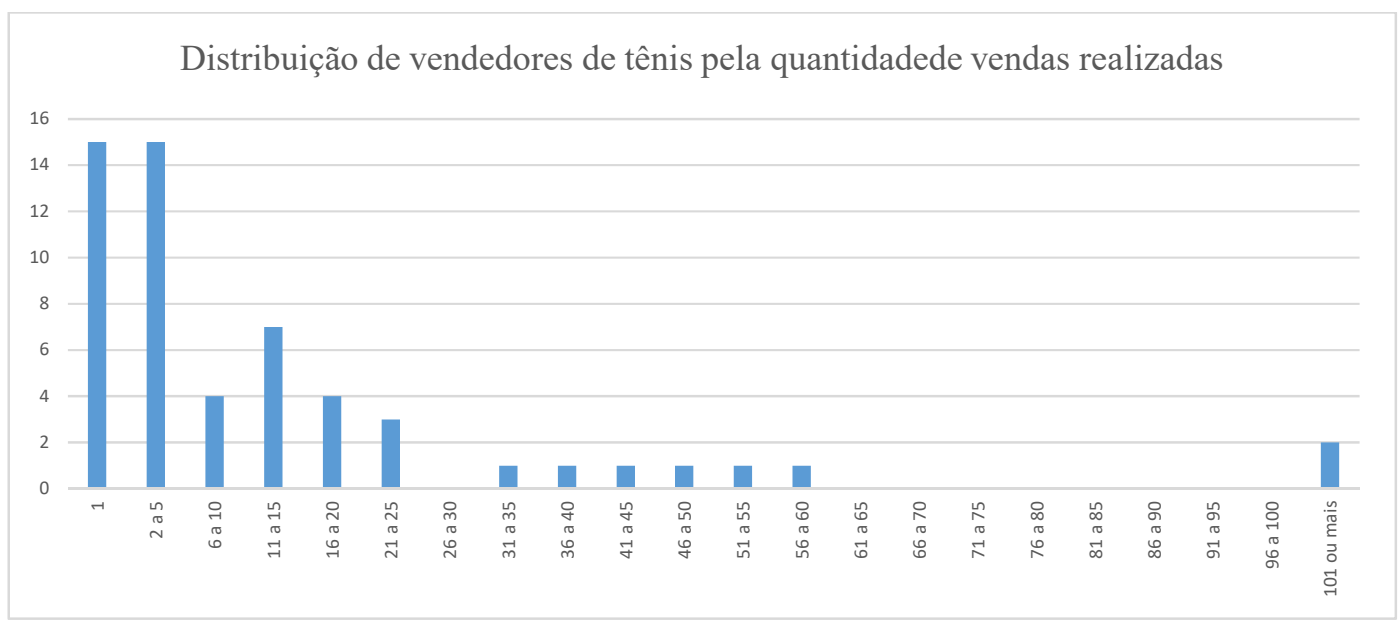

Fonte: Elaborado pelo autor. 
Diferente do que foi observado no caso dos iPhones e dos Playstations 4, o gráfico de distribuição dos vendedores de tênis de acordo com a quantidade de vendas (Figura 29) apresentou um formato ligeiramente diferente do gráfico de distribuição dos anúncios (Figura 26). Não há nenhum anúncio com mais de 100 unidades de tênis vendidas. $\mathrm{O}$ anúncio com mais vendas possui apenas 53 unidades. No entanto, há dois vendedores que realizaram mais de cem vendas. Os vendedores de tênis são os que mais publicam anúncios similares, possivelmente para destacar os diversos modelos, com uma média de 3,45 anúncios por vendedor (193 anúncios distintos publicados por 56 vendedores). A Tabela 20 sumariza a participação dos vendedores de cada porte no total de unidades vendidas.

Tabela 29 - Participação dos vendedores no total de vendas

\begin{tabular}{|c|c|c|c|c|c|c|c|c|c|}
\hline \multirow{2}{*}{$\begin{array}{l}\text { Vendas por } \\
\text { vendedor }\end{array}$} & \multicolumn{3}{|c|}{ iPhone } & \multicolumn{3}{|c|}{ PS4 } & \multicolumn{3}{|c|}{ Tênis } \\
\hline & \begin{tabular}{|c|} 
Vended. \\
Distintos
\end{tabular} & Vendas & $\begin{array}{c}\text { Vendas } \\
(\%)\end{array}$ & $\begin{array}{l}\text { Vended. } \\
\text { Distintos }\end{array}$ & Vendas & \begin{tabular}{|c|} 
Vendas \\
$(\%)$
\end{tabular} & \begin{tabular}{|c|} 
Vended. \\
Distintos
\end{tabular} & Vendas & \begin{tabular}{|c} 
Vendas \\
$(\%)$
\end{tabular} \\
\hline 1 & 326 & 326 & $19 \%$ & 318 & 318 & $3 \%$ & 15 & 15 & $2 \%$ \\
\hline 2 a 5 & 65 & 185 & $11 \%$ & 128 & 374 & $4 \%$ & 15 & 46 & $5 \%$ \\
\hline 6 a 10 & 19 & 145 & $8 \%$ & 32 & 253 & $2 \%$ & 4 & 34 & $4 \%$ \\
\hline 11 a 15 & 6 & 77 & $4 \%$ & 17 & 223 & $2 \%$ & 7 & 87 & $10 \%$ \\
\hline 16 a 20 & 6 & 109 & $6 \%$ & 15 & 260 & $3 \%$ & 4 & 71 & $8 \%$ \\
\hline 21 a 25 & 1 & 23 & $1 \%$ & 8 & 179 & $2 \%$ & 3 & 66 & $8 \%$ \\
\hline 26 a 30 & 3 & 80 & $5 \%$ & 6 & 167 & $2 \%$ & 0 & 0 & $0 \%$ \\
\hline 31 a 35 & 0 & 0 & $0 \%$ & 2 & 64 & $1 \%$ & 1 & 31 & $4 \%$ \\
\hline 36 a 40 & 3 & 112 & $6 \%$ & 5 & 191 & $2 \%$ & 1 & 38 & $4 \%$ \\
\hline 41 a 45 & 1 & 44 & $3 \%$ & 5 & 218 & $2 \%$ & 1 & 43 & $5 \%$ \\
\hline 46 a 50 & 3 & 143 & $8 \%$ & 2 & 96 & $1 \%$ & 1 & 49 & $6 \%$ \\
\hline 51 a 55 & 2 & 107 & $6 \%$ & 2 & 104 & $1 \%$ & 1 & 51 & $6 \%$ \\
\hline 56 a 60 & 0 & 0 & $0 \%$ & 3 & 177 & $2 \%$ & 1 & 58 & $7 \%$ \\
\hline 61 a 65 & 0 & 0 & $0 \%$ & 1 & 65 & $1 \%$ & 0 & 0 & $0 \%$ \\
\hline 66 a 70 & 0 & 0 & $0 \%$ & 2 & 136 & $1 \%$ & 0 & 0 & $0 \%$ \\
\hline 71 a 75 & 0 & 0 & $0 \%$ & 1 & 71 & $1 \%$ & 0 & 0 & $0 \%$ \\
\hline 76 a 80 & 1 & 80 & $5 \%$ & 1 & 77 & $1 \%$ & 0 & 0 & $0 \%$ \\
\hline 81 a 85 & 0 & 0 & $0 \%$ & 1 & 84 & $1 \%$ & 0 & 0 & $0 \%$ \\
\hline 86 a 90 & 0 & 0 & $0 \%$ & 0 & 0 & $0 \%$ & 0 & 0 & $0 \%$ \\
\hline 91 a 95 & 1 & 92 & $5 \%$ & 0 & 0 & $0 \%$ & 0 & 0 & $0 \%$ \\
\hline 96 a 100 & 1 & 96 & $6 \%$ & 0 & 0 & $0 \%$ & 0 & 0 & $0 \%$ \\
\hline $\begin{array}{c}101 \text { ou } \\
\text { mais }\end{array}$ & 1 & 110 & $6 \%$ & 25 & 7303 & $70 \%$ & 2 & 260 & $31 \%$ \\
\hline Total & 439 & 1729 & $100 \%$ & 574 & 10360 & $100 \%$ & 56 & 849 & $100 \%$ \\
\hline
\end{tabular}

Fonte: Elaborado pelo autor. 


\subsection{Fatores de influência do preço}

A partir dos dados expostos nas seções anteriores foi gerada uma regressão linear em que o preço é a variável dependente e as variáveis do modelo, introduzidas nos capítulos anteriores e mapeadas na Tabela 14 são as variáveis independentes.

Dois elementos apresentaram uma quantidade muito pequena de ocorrências. Praticamente todas as vendas permitiam o envio do produto através do Mercado Envios (variável MERCADOENVIOS). Como detalhado nas tabelas das seções anteriores, das 12955 vendas realizadas, em apenas $136(0,01 \%)$ o vendedor optou por não disponibilizar esta opção de frete. A mesma situação ocorreu com a variável LOJAOFICIAL. Ocorreram apenas 6 vendas através destas lojas. Por este motivo, estes dois fatores foram retirados do modelo.

Uma situação parecida ocorreu com o TERMÔMETRO. Há um volume considerável de transações realizadas por vendedores novos, sem indicação de cor no termômetro, e uma grande quantidade de vendas realizadas por vendedores nos níveis amarelo, verde claro e verde escuro. Porém, praticamente não foram realizadas por vendedores nas cores laranja e vermelho. Assim, excluiu-se do modelo as cores laranja e vermelho, deixando apenas as outras cores. Desta forma, entende-se que um vendedor sem indicação de cor, no modelo, pode ser um vendedor novo (sem termômetro) ou com cores laranja ou vermelho.

Finalmente, observou-se que os valores relacionados à IDADEDOVENDEDOR e a IDADEDOANÚNCIO, assim como à quantidade de TRANSAÇÕESCOMPLETAS e QTDVENDAANÚNCIO possuem uma enorme variação. Existem tanto vendedores que acabaram de realizar a primeira venda quanto vendedores com mais de 144 mil transações. É de interesse do estudo observar se um vendedor mais antigo e experiente consegue vender por um preço maior ou não que um vendedor novo, mas esta amplitude distorceria os resultados do modelo. Assim, foi considerado no modelo o valor do logaritmo natural destas variáveis ao invés do seu valor original.

Especificamente para as vendas de tênis também foi excluído do modelo a variável VÍDEO, pois não ocorreram vendas nos anúncios que adotavam este recurso. Também não houve vendas nos anúncios gratuitos deste produto. Por isso a variável TIPODEANUNCIOPREMIUM não foi considerada. Apesar de existirem vendas em anúncios premium, como não ocorreram 
vendas em anúncios gratuitos, a variável TIPODOANUNCIOCLASSICO é suficiente para a análise. Ou seja, todas as vendas de tênis que não possuem 1 como TIPODOANUNCIOCLASSICO, são do tipo premium.

A seguinte equação passou a representar o modelo:

PREÇO $=$ INTERCEPTO + TERMOMETROAMERALO +

TERMOMETROVERDECLARO + $\quad$ TERMOMETROVERDEESCURO +

PERCENTNEGATIVO + LNIDADEDOVENDEDOR + MERCADOLIDERSILVER +

MERCADOLIDERGOLD + MERCADOLIDERPLATINUM +

LNTRANSACOESCOMPLETAS + NACAPITAL + QTDFOTOS + VIDEO + EMITENF + GARANTIA + FRETEGRATIS + TIPODOANUNCIOCLASSICO + TIPODOANUNCIOPREMIUM + LNIDADEDOANUNCIO + LNQTDVENDANUN + ESTADODOITEMNOVO + NACAIXA

No caso do PS4 foi incluída também a variável DOISCONTROLES.

Para verificar a existência de multicolinearidade entre as variáveis preditoras do modelo foram examinados os fatores de inflação da variância (VIF), apresentados na Tabela 30.

Tabela 30 - Fatores de inflação da variância (VIF)

\begin{tabular}{|l|c|c|c|c|c|}
\hline Elemento & iPhone & PS4 & PS4 v2 & Tênis & Tênis v2 \\
\hline TERMOMETROAMERELO & 1,66 & 1,86 & 1,85 & 4,04 & 1,12 \\
\hline TERMOMETROVERDECLARO & 3,83 & 3,33 & 3,33 & 96,55 & N/A \\
\hline TERMOMETROVERDEESCURO & 4,69 & 4,82 & 4,81 & 100,08 & 2,45 \\
\hline PERCENTNEGATIVO & 1,12 & 1,13 & 1,13 & 2,05 & 1,25 \\
\hline LNIDADEDOVENDEDOR & 1,34 & 1,51 & 1,51 & 3,09 & 2,76 \\
\hline MERCADOLIDERSILVER & 1,18 & 1,24 & 1,24 & 1,34 & 1,32 \\
\hline MERCADOLIDERGOLD & 1,71 & 1,89 & 1,89 & 4,37 & 4,01 \\
\hline MERCADOLIDERPLATINUM & 3,04 & 5,49 & 5,48 & 6,50 & 5,95 \\
\hline LNTRANSACOESCOMPLETAS & 4,84 & 5,61 & 5,57 & 10,82 & 9,11 \\
\hline NACAPITAL & 1,52 & 1,21 & 1,21 & 1,11 & 1,09 \\
\hline QTDFOTOS & 1,36 & 1,20 & 1,19 & 1,35 & 1,34 \\
\hline VIDEO & 1,73 & 1,25 & 1,25 & $\mathrm{~N} / \mathrm{A}$ & N/A \\
\hline EMITENF & 1,17 & 1,10 & 1,10 & 1,49 & 1,28 \\
\hline GARANTIA & 2,03 & 1,47 & 1,48 & 2,00 & 1,64 \\
\hline FRETEGRATIS & 1,46 & 1,20 & 1,20 & 1,24 & 1,22 \\
\hline TIPODOANUNCIOCLASSICO & 3,32 & 23,35 & N/A & 1,81 & 1,80 \\
\hline
\end{tabular}




\begin{tabular}{|l|c|c|c|c|c|}
\hline TIPODOANUNCIOPREMIUM & 2,51 & 23,11 & 1,24 & 5,62 & 5,42 \\
\hline LNIDADEDOANUNCIO & 1,92 & 2,66 & 2,66 & 0,04 & 4,12 \\
\hline LNQTDVENDANUN & 2,77 & 2,80 & 2,80 & 160,54 & 2,57 \\
\hline ESTADODOITEMNOVO & 1,82 & 4,30 & 1,42 & N/A & N/A \\
\hline NACAIXA & 1,25 & 1,13 & 1,13 & 126,53 & N/A \\
\hline DOISCONTROLES & N/A & 1,22 & 1,22 & N/A & N/A \\
\hline
\end{tabular}

Fonte: Elaborado pelo autor

Para as vendas de iPhone, os valores de VIF encontrados para as variáveis estão todos entre 1 e 5, indicando que a correlação entre as variáveis é moderada, não sendo um problema para esta regressão.

No caso do Playstation 4, os valores de MERCADOLIDERPLATINUM e LNTRANSACOESCOMPLETAS são ligeiramente superiores a 5, indicando uma correlação mais forte mas ainda não forte o suficiente para invalidar os valores da regressão. Apenas as variáveis TIPODOANUNCIOCLASSICO e TIPODOANUNCIOPREMIUM apresentaram-se realmente como extremamente correlacionados. Optou-se então por retirar a variável TIPODOANUNCIOCLASSICO do modelo e todos os valores de VIF ficaram abaixo de 5, excetuando-se os dois que já estavam ligeiramente acima e assim permaneceram.

Mais casos problemáticos foram observados ao examinar-se as vendas de tênis. Valores de VIF indicando extrema correlação foram encontrados para as variáveis TERMOMETROVERDECLARO, TERMOMETROVERDEESCURO, NACAIXA, LNQTDVENDANUN e LNTRANSACOESCOMPLETAS. Optou-se, então, por retirar do modelo nas análises das vendas deste produto as variáveis TERMOMETROVERDECLARO e NACAIXA.

A Tabela 31 mostra o resultado desta regressão para cada um dos produtos. Nela, os valores assinalados com $* * *$ são extremamente significantes ( $\mathrm{p}$ menor que 0,001 ). Os sinalizados por ** são muito significantes ( $\mathrm{p}$ entre 0,001 e 0,01). Com apenas um asterisco estão os significantes ( $p$ entre 0,01 e 0,05). Assinalados com um “+” estão os valores menos significantes ( $p$ entre 0,05 e 0,1) e sem marcação os sem significância estatística. 
Tabela 31 - Resultado da regressão

\begin{tabular}{|l|c|c|c|}
\hline Elemento & iPhone & PS4 & Tênis \\
\hline INTERCEPTO & $1365.8715 * * *$ & $1175,8122 * * *$ & $45,6096 * * *$ \\
\hline TERMOMETROAMERELO & -25.7104 & $-15,3202$ & 14,4461 \\
\hline TERMOMETROVERDECLARO & $93.671 * * *$ & $25,4012 *$ & $10,3278 * * *$ \\
\hline TERMOMETROVERDEESCURO & $126.2233 * * *$ & $63,2430 * * *$ & 22,7703 \\
\hline PERCENTNEGATIVO & $-148.3239 * * *$ & $-154,5727 * * *$ & $-56,7094 * *$ \\
\hline LNIDADEDOVENDEDOR & $53.1554 * * *$ & $-7,5049 *$ & $6,3167 *$ \\
\hline MERCADOLIDERSILVER & $56.9073 * *$ & $36,6880 * * *$ & $-9,1776 * * *$ \\
\hline MERCADOLIDERGOLD & $117.0451 * * *$ & $16,9254 * *$ & $-9,1470 * *$ \\
\hline MERCADOLIDERPLATINUM & $49.4529 * *$ & $-18,9242 * *$ & $-9,0532 * *$ \\
\hline LNTRANSACOESCOMPLETAS & $-42.3645 * * *$ & $10,7266 * * *$ & 1,6046 \\
\hline NACAPITAL & $-29.1723 * *$ & $7,1434 *$ & $-0,5381$ \\
\hline QTDFOTOS & $-12.8579 * * *$ & $8,9977 * * *$ & $0,3949 * * *$ \\
\hline VIDEO & -25.7786 & $27,1314 * * *$ & N/A \\
\hline EMITENF & $37.9115 * *$ & $-20,4154 * * *$ & 4,9343 \\
\hline GARANTIA & 14.7208 & $45,5626 * * *$ & $-3,5486+$ \\
\hline FRETEGRATIS & $51.8027 * * *$ & $21,1239 * * *$ & $26,9697 * * *$ \\
\hline TIPODOANUNCIOCLASSICO & $110.2508 * * *$ & $95,1893 * * *$ & $21,2221 * * *$ \\
\hline TIPODOANUNCIOPREMIUM & 7.7137 & N/A & N/A \\
\hline LNIDADEDOANUNCIO & $60.378 * * *$ & $16,8101 * * *$ & $6,1686 *$ \\
\hline LNQTDVENDANUN & -0.7961 & $-12,1147 * * *$ & $-1,9099 * * *$ \\
\hline ESTADODOITEMNOVO & $200.7695 * * *$ & 0,3819 & N/A \\
\hline NACAIXA & $22.5643 *$ & $49,8104 * * *$ & N/A \\
\hline DOISCONTROLES & N/A & $218,9126 * * *$ & N/A \\
\hline $\mathrm{R}^{2}$ Múltiplo & 0,5208 & 0,4839 & 0,6446 \\
\hline R 2 Ajustado & 0,5149 & 0,4829 & 0,6378 \\
\hline
\end{tabular}

Fonte: Elaborado pelo autor

O erro residual padrão para as vendas de iPhone foi 161,20 (1707 graus de liberdade 1707), para o PS4 foi 126,50 (10.337 graus de liberdade) e para o tênis 17,48 (830 graus de liberdade).

\subsubsection{Influência da reputação do vendedor}

A primeira hipótese levantada no Capítulo 2 deste trabalho é sobre a influência da reputação do vendedor na geração do preço-prêmio. Diversas pesquisas destacam que vendedores que constroem uma boa pontuação consegue, realizar vendas com preços mais altos e vendedores com reputação negativa precisam trabalhar com preços menores (HOUSER e WOODERS, 2006; JOLIVET, JULLIEN e POSTEL-VINAY, 2016; LUCKING-REILEY, BRYAN, et al., 
2007; MELNIK e ALM, 2005; PRZEPIORKA, 2013; RESNICK, ZECKHAUSER, et al., 2006). Os resultados deste trabalho corroboram neste sentido.

Observou-se que vendas de iPhones realizadas pelos vendedores classificados com termômetro verde escuro atingem valores $\mathrm{R} \$ 125,56$ maiores que vendas similares realizadas por vendedores que não possuem esta sinalização de boa reputação. Como também esperado, os vendedores com uma classificação um pouco mais baixa, verde claro, vendem por um preço superior aos classificados em nível inferior ou sem classificação, mas inferior aos de melhor classificação. Este comportamento, com diferentes intensidades (e com valores de maior ou menor significância), é observado para todos os produtos.

Assim como uma reputação positiva, indicada pela cor do termômetro, leva a preços mais altos, observou-se que uma reputação negativa, indicada pelo percentual de avaliações negativas recebidas, tem o efeito oposto. Vendedores que recebem feedbacks negativos de seus compradores anteriores são penalizados nos valores de suas vendas. Este impacto foi percebido em todos os produtos. No entanto, diferente do que ocorreu com os sinais positivos, que os efeitos foram maiores no iPhone, o efeito da pontuação negativa é muito parecido entre as vendas de iPhone e de PS4.

Em relação às vendas realizadas por vendedores que estão na cor amarela, percebeu-se que este sinal de reputação impacta nos valores das vendas e faz com que estes sejam valores inferiores ao dos vendedores novos (sem termômetro). Apesar de não serem estatisticamente significantes, estes valores indicam que o consumidor entende o amarelo como um indicador da reputação negativa do vendedor. Os compradores pagam mais pela incerteza de comprar de um vendedor novo que para o risco percebido ao transacionar com um vendedor mal avaliado.

O último fator relacionado à reputação observado foi a "idade" do vendedor na plataforma. Isto é, a quantidade de dias a partir da criação da conta do usuário vendedor. Vendedores que conseguem se manter na plataforma por mais tempo poderiam ser vistos como mais confiáveis pelos compradores que, consequentemente, estariam dispostos a pagar mais.

Conseguimos observar um comportamento neste sentido para as vendas de iPhone e de tênis. Quanto mais antiga era a conta do vendedor, maior o preço de suas vendas. Mas, contraintuitivamente, o mesmo não foi observado nas vendas de videogame. $\mathrm{O}$ fato da conta do 
vendedor ser antiga, para este produto, acabou contribuindo para que suas vendas fossem de menor valor.

\subsubsection{Influência do porte do vendedor}

Uma expectativa inicial era que vendedores de maior porte, que já realizaram muitas vendas na plataforma, seriam preferidos pelos compradores e, por isso, conseguiriam praticar maiores preços. Observando-se os valores adicionais nas transações dos vendedores com selos de MercadoLíder, principalmente para o iPhone, há indícios de que esta hipótese é verdadeira.

No entanto, um resultado que discorda deste argumento é encontrado quando se observa que um vendedor de iPhone com selo de MercadoLíder Platinum realiza transações por um valor menor que um MercadoLíder Gold. Nas vendas de PS4, esta tendência é ainda mais clara. Para este produto quanto maior é o porte do vendedor, de acordo com a escala de MercadoLíder, menor é o preço de suas vendas. O preço praticado por um vendedor de tênis MercadoLíder Silver é superior ao de um MercadoLíder Gold, que, por sua vez, é superior ao de um MercadoLíder Platinum. Neste caso, observa-se inclusive que os vendedores que possuem o selo Platinum chegam a realizar vendas por valores inferiores aos que não são MercadoLíder. O mesmo acontece para as vendas de tênis mas, para este produto, todos os valores são negativos e bastante próximos.

É importante lembrar que para ser MercadoLíder o vendedor precisa estar na classificado como verde escuro no termômetro. Um valor negativo para a presença de selos do MercadoLíder, principalmente quando estes valores são de menor grandeza que os apresentados para a variável do termômetro verde escuro, não significa que estes vendedores estão praticando preços inferiores que novos usuários ou que vendedores mal avaliados. Mas, levando-se em consideração que a classificação de MercadoLíder utiliza como critério o faturamento do usuário, significa que vendedores que faturam alto praticam menores preços.

Os compradores de iPhone valorizam mais os selos que os dos outros produtos e pagam mais caro por isso. Os usuários que adquirem tênis, possivelmente por este ser um produto de menor valor, não pagam a mais pelo selo de MercadoLíder. Já para PS4, os compradores enxergam valor nos selos e compram mais caro na presença deles. Mas possivelmente devido a concorrência entre o alto número de grandes vendedores deste produto faz com que vendedores 
Platninum, que possuem faturamento trimestral acima de $\mathrm{R} \$ 320.000,00$, pratiquem preços tão agressivos que os benefícios da presença do selo para o valor da venda não é percebido.

O número de transações realizadas anteriormente pelo perfil do vendedor, representado pela variável LNTRANSACOESCOMPLETAS, é um indicador de porte do vendedor que não leva em consideração o seu faturamento, mas o número absoluto de transações realizadas. Entre estas transações anteriores podem constar, por exemplo, acessórios como capinhas de celular, jogos e controles.

Vendedores de Playstation e de Tênis com um histórico de muitas transações anteriores acabam transacionando com preços maiores que os vendedores com poucas vendas. Ao contrário do esperado, mais antigo é o vendedor de iPhone, menor é o preço das suas vendas.

\subsubsection{Influência da localização do vendedor}

A terceira hipótese levantada por este trabalho é que vendedores localizados grandes centros vendem com preços diferentes dos vendedores localizados em cidades menores. Entende-se que a maioria dos compradores estão nos grandes centros e estariam dispostos a pagar um pouco mais caro para comprar de alguém na mesma cidade para receber seu item mais rapidamente, economizar os custos do frete ou simplesmente por uma questão de confiança. Por outro lado, também há maior disponibilidade de itens nas cidades maiores e, devido à concorrência, vendedores destas cidades poderiam trabalhar com preços menores.

Analisando os dados observamos que, conforme esperado, há de fato a influência da localização no preço e que esta influência é diferente de acordo com o produto. Compradores de iPhone, possivelmente pelo seu tamanho reduzido que facilita o envio, não pagam mais caro se o item está disponível na capital. O mesmo, possivelmente pelo mesmo motivo, mas com valores nãosignificantes, foi observado nas vendas de tênis. Já os consumidores de PS4, que é maior e mais pesado, estão dispostos a pagar um pouco mais por um videogame que não esteja em uma cidade do interior.

\subsubsection{Influência dos recursos multimídia do anúncio}


Em um produto mais homogêneo, como o iPhone novo e o PS4 novo, o comprador sabe exatamente o que espera do produto apenas pela sua descrição. Não era esperado que a fotos e vídeos fossem muito relevantes para o preço final da venda. Já para produtos que carecem de maior explicação, como itens usados ou tênis, os recursos multimídia poderiam ajudar na explicação do produto e, por consequência, possibilitarem a realização de vendas com valores maiores.

Analisando os resultados da regressão percebe-se que, realmente, quanto mais fotos foram inseridas nos anúncios de tênis, maior foi o valor das vendas. O mesmo foi observado nas vendas de Playstation 4. Cada foto adicional que o vendedor inclui do videogame representou um adicional de $\mathrm{R} \$ 9,00$ no valor de suas vendas e um vídeo representou um aumento de $\mathrm{R} \$ 27,13$. Para os iPhones foi observado que as vendas que mais possuíam fotos ocorreram com valores mais baixos. Assim como ocorreu com os anúncios de PS4, a utilização de vídeos intensificou o efeito.

Não está claro o que causa esta diferença. Uma possibilidade, que poderia ser explorada em mais detalhes em outro estudo, é que não há qualquer variação entre os modelos de iPhone vendidos (exceto a cor e o país de fabricação) mas há diferenças de versões do videogame sendo negociadas (edições especiais, versão slim ou tradicional, com jogos de brinde etc.). A utilização de muitos recursos multimídia, para este produto serviria para mostrar diferenciais que aumentam o preço, já para o telefone seria para explicar problemas (como arranhões, vidros trincados etc.).

\subsubsection{Influência da nota fiscal e garantia}

Evidenciar no anúncio que o item será enviado com nota fiscal permite ao vendedor de iPhone realizar vendas por $\mathrm{R} \$ 37,91$ a mais que um vendedor que não emite a nota, ou não deixa esta informação evidente no anúncio. Novamente, um comportamento diferente foi observado para as vendas de Playstation 4. Para este produto, os compradores pagam mais caro quando não foi mencionado que o item seria enviado com nota fiscal.

Este estudo não explica os motivos deste comportamento. Talvez uma explicação possa estar na expectativa do consumidor quando compra um item no Mercado Livre e na importância que ele dá para a nota físcal. As pessoas que estão comprando neste site, em geral, procuram preços 
mais baratos que os encontrados em lojas convencionais. Quando um anúncio informa que envia com nota fiscal, o comprador pode ter a sensação que está comprando de uma loja tradicional e apenas seguir com a transação ao certificar-se que está realmente conseguindo um menor preço. Este comportamento não ocorreria no caso dos telefones pois os consumidores de celular, que ocasionalmente precisam apresentar a nota fiscal na operadora ou para acionar a garantia do fabricante, valorizariam mais este documento e pagam mais por isso.

Uma forma que vendedores de produtos de preço mais alto (iPhone e Playstation) podem conseguir realizar vendas com maior valor é oferecendo uma garantia adicional. Os compradores destes produtos valorizam a garantia. Esta diferença foi maior para os videogames (acréscimo de $\mathrm{R} \$ 45,56)$ que para os celulares (acréscimo de $\mathrm{R} \$ 14,72$, não significantes). Possivelmente isto ocorre pois há um grande volume de celulares e videogames importados sendo comercializados. A Apple oferece garantia de um ano para todos os iPhones dos modelos comercializados oficialmente no Brasil, independente de qual o país de origem deles. Já a Sony, fabricante do Playstation, apenas oferece garantia para videogames fabricados no Brasil. Com isso, os compradores valorizam mais a garantia do vendedor para este produto. Este posicionamento do fabricante possivelmente também reforça a pouca importância atribuída a nota fiscal para o Playstation 4.

\subsubsection{Influência do frete gratuito no preço}

Ao anunciar que um item possui frete gratuito, o vendedor está, na realidade, responsabilizando-se pelo pagamento do envio. O custo de todos os envios somados será incorporado aos custos operacionais do vendedor e pode ser acrescentado ao valor final. Por isso, espera-se que as vendas realizadas com frete gratuito tenham um valor superior as vendas cujo frete é cobrado separadamente. Na comparação de preços, o comprador leva em consideração que há valores de entrega e aceita pagar um pouco a mais pelo produto se não precisar arcar com este custo.

Este comportamento ficou bastante claro em todos os produtos, principalmente entre as vendas de iPhone. Oferecer frete gratuito possibilita aos vendedores de iPhone realizar transações com preços $\mathrm{R} \$ 51,80$ mais elevados. O frete gratuito representou um aumento de $\mathrm{R} \$ 21,12$ para as vendas de videogame e de $\mathrm{R} \$ 26,97$ para as vendas de tênis. 
Os celulares são produtos pequenos, compactos, de fácil logística. Mesmo pagando pelo envio, este acréscimo aparenta ser vantajoso ao vendedor. Vale ressaltar que, ao definir se irá ou não adotar esta estratégia, o vendedor também deve levar em consideração outros fatores. Por exemplo, é possível que a oferta de frete gratuito seja um diferencial e facilite a realização de mais vendas. Ou que o aumento do preço acabe espantando compradores. Esta discussão está fora do escopo deste estudo. Observou-se apenas que o volume de vendas com frete gratuito foi elevado em todos os produtos: $61,5 \%$ das vendas de iPhone, $21,8 \%$ das vendas de Playstation e $47,8 \%$ das vendas de tênis.

\subsubsection{Influência do tipo do anúncio no preço}

Anúncios no Mercado Livre que não pagam por mais visibilidade e recursos adicionais são completamente gratuitos. Os vendedores que optarem por um anúncio com maior exibição, chamado de Clássico, pagam uma taxa de $11 \%$ a cada venda. Se preferirem ainda mais exposição podem pagar 16\% de taxa por um anúncio Premium. Este tipo de anúncio também permite que os compradores possam pagar o valor parcelado no cartão sem juros.

Nas regressões do Playstation 4 e do tênis, excluiu-se a variável referente aos anúncios premium. Como todas as vendas de tênis foram realizadas por anúncios pagos, para este produto, isto significa que o valor de referência é o anúncio premium. Ou seja as vendas que tiveram o valor 0 atribuído para a variável dummy referente aos anúncios clássicos foram realizdas através de anúncios premium. Já para o videogame, a eliminação da variável ocorreu para reduzir os efeitos da multicolinearidade. O valor de referência é o anúncio gratuito e a variável TIPODOANUNCIOCLASSICO agrupa os anúncios clássicos e premium.

A maior exposição dos anúncios possibilitou aos vendedores trabalharem com preços superiores em todos os produtos. Anúncios do tipo Clássico fizeram vendas de iPhone por $\mathrm{R} \$ 110,25$ a mais que os gratuitos. Pagar por exposição possibilitou aos vendedores de Playstation 4 fechar negócios por $\mathrm{R} \$ 95,19$ a mais que os anúncios gratuitos.

Nas vendas de tênis observamos apenas que os anúncios clássicos conseguem vender por preços maiores que os anúncios premium. Este cenário indica que, desconsiderando outros fatores, não é vantajoso utilizar anúncios deste tipo. Outros fatores, aqui não explorados, como a 
possibilidade de realizar mais vendas ou de vender um item mais rapidamente, podem tornar este anúncio atrativo para o vendedor.

O número de vendas realizadas por anúncios pagos, nas duas modalidades, é realmente mais alto. Apenas 5\% das vendas de videogame e 19\% das vendas de celular foram realizadas por anúncios gratuitos. Por este motivo, é possível que vendedores que querem maior escala prefiram trabalhar com anúncios pagos. Para pessoas que desejam vender apenas uma unidade e podem esperar até a venda ocorrer, pode ser mais vantajoso anunciar gratuitamente por um preço um pouco inferior e evitar o pagamento da taxa.

\subsubsection{Influência do histórico do anúncio no preço}

O comprador não consegue facilmente saber quando um anúncio foi publicado. Mas anúncios mais antigos vão sendo aperfeiçoados pelo vendedor ao longo do tempo, que aprende o que dá resultado, melhora o seu discurso e a apresentação do produto. Estes anúncios, como apresentado na seção 4.2.4, também podem conseguir construir uma notoriedade em outros sites, passando a receber visitas diretamente (e não só pelas buscas do Mercado Livre).

Além disso, em cada anúncio há uma seção na qual compradores potenciais fazem perguntas para o vendedor. Se um comprador fica com dúvidas e precisa fazer uma pergunta perde-se a chance de realizar a venda naquele momento. No tempo entre a pergunta e a resposta, o consumidor pode encontrar o produto em outro lugar e preferir comprar nele (ou simplesmente desistir da compra). Anúncios mais antigos constroem um histórico de perguntas e respostas que ajudam a explicar melhor o anúncio e já apresentam a resposta para as perguntas mais frequentes.

Como esperado, os anúncios mais antigos apresentaram vendas com valores mais altos que anúncios mais novos. Isso foi percebido em todos os produtos, sendo mais intenso e estatisticamente significante nos produtos de preço mais elevado.

Inicialmente esperava-se que a quantidade de unidades vendidas por cada anúncio, que é visível ao comprador, exercesse influência na confiança percebida e, por isso, também permitisse a venda por valores mais altos. Mas este efeito não foi confirmado. Quanto mais unidades foram vendidas por um anúncio, menor foi o valor de cada venda. Apesar de não corresponder com a 
expectativa inicial, este resultado é coerente quando consideramos que há grandes vendedores na plataforma. Alguns anúncios apresentam margens menores e realizam muitas vendas. Neles os vendedores esperam lucrar através do grande volume de transações.

\subsubsection{Influência do produto no preço}

Durante as análises apresentadas nas seções anteriores, em diversos momentos ficou claro um comportamento distinto entre os produtos. Estas diferenças foram desde que a intensidade da importância de determinado elemento, como o termômetro do vendedor na cor verde escuro, até o sentido da sua influência, como na emissão ou não de nota físcal.

Além do ajuste dos coeficientes das varáveis que caracterizam o vendedor e o anúncio, há alguns elementos específicos do produto que influenciam seu preço. O primeiro fator observado foi o estado do item. Produtos novos apresentam preços superiores aos usados. $\mathrm{O}$ fato de um iPhone ser novo fez com que o valor de suas vendas fossem $\mathrm{R} \$ 200,77$ mais altos que um outro aparelho usado. Para os videogames, este incremento foi menor, mas também estatisticamente significante. A venda de tênis usados não foi considerada neste trabalho.

Outro fator também valorizado pelos compradores é o envio do item na caixa. Mais do que simplesmente enviar o produto na caixa original, é interessante para o vendedor deixar isto claro em seu anúncio.

Por último, conforme introduzido na seção 4.2.2, é prática comum entre os anúncios de Playstation 4 a inclusão de um controle adicional. Formar um pacote com o aparelho e um controle em uma mesma venda é uma forma de aumentar o valor final da transação. $\mathrm{O}$ valor acrescentado nas vendas que possuíam dois controles $(\mathrm{R} \$ 218,99)$ deixa evidente que, de fato, o segundo controle não é um brinde e os consumidores aceitam pagar mais caro por ele. 


\section{CONSIDERAÇÕES FINAIS}

Este trabalho revisou estudos anteriores para encontrar seus principais achados em relação a geração de preço-prêmio em e-marketplaces voltados para o consumidor (B2C e C2C). Os achados destas pesquisas foram adaptados à realidade brasileira, com mais vendas em formato de preço fixo (classificado) que variável (leilão) e um modelo foi proposto.

No modelo apresentado a geração de preço-prêmio de uma venda em um EM é influenciada pelas características do anúncio, do vendedor e do produto. A partir do modelo, foram elaboradas nove hipóteses sobre os elementos controláveis pelo vendedor e sua influência no preço das vendas. Em seguida, um estudo empírico foi realizado para verificar estas hipóteses. Foram coletados dados de vendas de iPhone, Playstation 4 e tênis Osklen femininos realizadas no MercardoLivre nos dois primeiros meses de 2017.

A primeira hipótese, $\mathrm{H1}$, que considera a influência da reputação do vendedor no preço da venda, foi validada. O efeito, medido a partir do termômetro do vendedor no Mercado Livre e do percentual de avaliações negativas, foi percebido tanto no bônus pago aos vendedores com boa reputação quanto na punição dos mal avaliados. A importância do número de dias desde a criação da conta do vendedor como indicador de reputação capaz de influenciar o preço das vendas apresentou resultados não conclusivos.

A hipótese $\mathrm{H} 2$, que trata da influência do porte do vendedor, não apresentou resultados tão claros. A presença de selos de MercadoLider, que caracterizam porte, inicialmente ajudam na realização de vendas com preços mais altos. Mas quando o porte dos vendedores é muito grande, os preços das vendas são até menores que os demais vendedores. A partir de qual porte um vendedor começa a vender mais barato que os demais, e a intensidade disso, varia de acordo com o produto. No tênis, desde a primeira faixa de MercadoLíder já há uma redução de preço, que repete-se nas demais faixas. No videogame, o vendedor do primeiro nível do MercadoLíder consegue vender mais caro, mas o valor diminui nas faixas superiores e chega a ser negativo na última. O melhor nível de MercadoLíder para o telefone é o intermediário (Gold), onde consegue-se o maior preço.

A última característica do vendedor considerada é que sua localização exerce influência no preço, discutida na hipótese H3. A hipótese não afirma que vendedores na capital ou no interior 
conseguem preços maiores ou menores, apenas que estes valores são diferentes. A hipótese é validada pelo estudo. A intensidade e o sentido desta importância varia de acordo com o produto.

As quatro hipóteses seguintes tratam das características do anúncio. A primeira delas, H4, sobre influência positiva da utilização de recursos multimídia foi validada para o tênis e para o videogame. Recursos multimídia ajudam a explicar os diferenciais destes produtos e geram preço-prêmio. No entanto, para o iPhone, estes recursos são utilizados principalmente nas vendas de menor valor.

A hipótese seguinte, H5, considera que há uma influência positiva pelo serviço prestado no anúncio, mais especificamente, quando há garantia e emissão de nota fiscal. Observa-se que o oferecimento a presença da nota fiscal é importante para o iPhone, e gera um valor adicional, mas não para o videogame e tênis. Nestes produtos os compradores até pagam menos quando ela é mencionada. Já a garantia adicional é uma boa forma de se conseguir vender com preços maiores, principalmente para o videogame. A influência da garantia no iPhone não é estatisticamente significante e é negativa para o tênis. Um fator que gerou preços maiores em todos os produtos, validando a hipótese H6, é o oferecimento de frete gratuito.

A hipótese seguinte, H7, considera que anúncios com maior exposição alcançam preços maiores. Isto foi confirmado entre os anúncios que pagam por mais destaque. A penúltima hipótese do trabalho e a última relacionada ao anúncio, H8, considera que um anúncio com um bom histórico influencia positivamente a geração de preço-prêmio. Esta hipótese é validada para todos os produtos quando consideramos a quantidade de dias desde a publicação do anúncio até a realização da venda. Mas não é verdadeira, também para todos os produtos, se observarmos a quantidade de vendas realizadas.

Finalmente, a hipótese H9 considera que há peculiaridades em cada categoria de produto e que a magnitude das influências observadas nas outras hipóteses varia de acordo com o que está sendo anunciado. As discussões anteriores validam esta hipótese. Além disso, há algumas características específicas do produto que influenciam positivamente a geração de preçoprêmio, como a presença de caixa, o estado do item e, no caso do videogame, o envio de um controle adicional. 


\subsubsection{Limitações}

Uma limitação técnica observada neste trabalho, já mencionada na metodologia, é realização das medições apenas uma vez por dia. Com isso, foram perdidas as vendas que foram anunciadas e realizadas no mesmo dia. Além disso, oscilações de preços ou de qualquer outra característica ao longo do dia também não foram capturadas (foram considerados sempre os valores apresentados no início do dia).

Outra limitação técnica está relacionada ao porte dos vendedores. Este estudo considera que cada usuário é um vendedor diferente. Mas há relatos em guias e tutoriais de vendedores que sugerem a criação de múltiplos usuários para um mesmo vendedor. Esta tática seria utilizada para facilitar a publicação de anúncios duplicados sem que haja punição do Mercado Livre (que também considera cada usuário como um vendedor diferente) e para evitar a interrupção completa das atividades caso uma das contas seja suspensa ou cancelada pelo EM. Não há pesquisas que expliquem quão comum é a adoção desta estratégia.

Este trabalho também observa apenas um conjunto limitado de fatores. Não levou-se em consideração outros elementos importantes como, por exemplo, a experiência do usuário comprador e a concorrência dos outros anúncios exibidos na plataforma a cada momento

\subsubsection{Sugestões para estudos futuros}

A coleta dos anúncios realizada por este trabalho gerou um banco de dados com milhares de anúncios que não realizaram nenhuma venda e, por não compor o escopo desta pesquisa, acabaram sendo descartados. Entre estes anúncios existem ofertas com diversos preços, de vários vendedores diferentes, com anúncios gratuitos e pagos. Sugere-se um estudo para entender os inibidores que fizeram com que estes anúncios não resultassem em vendas enquanto outros, muito similares, anunciados ao mesmo tempo, conseguiram seus objetivos.

Na mesma linha, entre os anúncios considerados neste trabalho, há um conjunto que apresentou um volume enorme de vendas. Um estudo sobre os fatores que influenciaram nesta quantidade de vendas também é interessante. Um estudo sobre este tema pode, inclusive, ser complementar a este e ajudaria a entender como balancear as características para se atingir um melhor resultado (preço x quantidade). Este trabalho ajudaria a entender quando aplicar determinada 
estratégia, como frete gratuito ou venda combinada com acessórios (como controle adicional) e quando é mais vantajoso trabalhar com preços mais baixos.

Outra sugestão de trabalho é a investigação dos e-marketplaces concorrentes do Mercado Livre, que apresentam um formato mais próximo de catálogo (e não de classificados). É o caso, por exemplo, do e-marketplace do Submarino, do MagazineLuiza ou do Extra. Nestes emarketplaces, cada produto possui apenas uma página. Ou seja, diferente do Mercado Livre, onde cada vendedor desenvolve seu anúncio, nestes EMs o anúncio é único e elaborado pelo administrador da plataforma. $\mathrm{O}$ vendedor possui menos recursos de personalização e apenas determina o preço da venda. Há vendedores que utilizam tanto o Mercado Livre quanto estas outras plataformas. Um estudo pode ser realizado para determinar a eficiência, as vantagens e desvantagens destas variações.

Finalmente, fica como sugestão para pesquisas futuras, aprofundar, talvez qualitativamente, nos pontos da análise realizada por este trabalho que apresentaram valores em sentidos opostos dependendo do produto. Por exemplo, seria interessante um estudo que ajudasse a explicar por que os anúncios de Playstation 4 que mencionam nota fiscal atingem preços de venda menores que os que não citam a emissão do documento. 


\section{REFERÊNCIAS}

ADAMS, C. P. Estimating demand from eBay prices. International Journal of Industrial Organization, v. 25, n. 6, p. 1213-1232, 2007.

AHN, T.; RYU, S.; HAN, I. The impact of Web quality and playfulness on user acceptance of online retailing, 44, n. 3, 2007. 263-275.

ALADWANI, A.; PALVIA, P. C. Developing and validating an instrument for measuringuser-perceived web quality. Information \& Management, 39, n. 6, 2002. 467-476.

ALEXA. Top Sites in Vrazil, 2016. Disponivel em: $<$ http://www.alexa.com/topsites/countries/BR>. Acesso em: 25 Maio 2016.

ALMENDRA, V. D. S.; SCHWABE, D. Um estudo de identificação de fraudadores em mercados eletrônicos através da computação humana. Tese de Doutorado - Departamento de Informática, Rio de Janeiro, 2008.

ALMENDRA, V. D. S.; SCHWABE, D. Analysis of Fraudulent Activity in a Brazilian Auction Site. 16th international conference on World Wide Web, Latin American Alternate Track. Madrid, Spain: [s.n.]. 2009.

ANDERSON, S. et al. Buy it now: A hybrid internet market institution, 9, n. 2, 2004. 1-41.

ANDERSON, S. et al. Seller strategies on eBay: Does size matter? International Journal of Electronic Business, 5, n. 6, 2007. 643-669.

BA, S.; PAVLOU, P. Evidence of the Effect of Trust Building Technology in Electronic Markets: Price Premiums and Buyer Behavior. MIS Quarterly, 26, n. 3, 2002. 243-268.

BAI, B.; LAW, R.; WEN, I. The impact of website quality on customer satisfaction and purchase intentions: Evidence from Chinese online visitors. International Journal of Hospitality Management, 27, n. 3, 2008. 391-402.

BAILEY, J. P.; BAKOS, Y. An exploratory study of the emerging role of electronic intermediaries. International Journal of Electronic Commerce, v. 1, n. 3, p. 7-10, 1997.

BAJARI, P.; HORTACSU, A. The Winner's Curse, Reserve Prices, and Endogenous Entry: Empirical Insights from eBay Auctions. The RAND Journal of Economics, v. 34, n. 99, p. 329-355, 2003.

BAKOS, Y. The emerging role of electronic marketplaces on the internet. Communications of the ACM, v. 41, n. 8, p. 35-42, 1998.

BAPNA, R.; JANK, W.; SHMUELI, G. Consumer surplus in online auctions. Information Systems Research, v. 19, n. 4, p. 400-416, 2008.

BELDAD, A.; JONG, M. D.; STEEHOUDER, M. How shall I trust the faceless and the intangible? A literature review on the antecedents of on-line trust. Computers in Human Behavior, 26, n. 5, 2010. 857-869. 
BENTE, G.; BAPTIST, O.; LEUSCHNER, H. To buy or not to buy: Influence of seller photos and reputation on buyer trust and purchase behavior. International Journal of Human Computer Studies, 70, n. 1, 2012. 1-13.

BLAND, E. M.; BLACK, G. S.; LAWRIM, K. Determinants of effectiveness and success for eBay auctions. The Coastal Business Journal , 4, n. 1, 2005. 5-15.

BRUCE, N.; HARUVY, E.; RAO, R. Seller rating, price, and default in online auctions. Journal of Interactive Marketing, v. 18, n. 4, p. 37-50, 2004.

BRUNN, P.; JENSEN, M.; SKOVGAARD, J. e-Marketplaces: Crafting A Winning Strategy. European Management Journal, v. 20, n. 3, p. 286-298, 2002.

CABRAL, L.; HORTACSU, A. The dynamics of seller reputation: Evidence from eBay. The Journal of Industrial Economics, v. 58, n. 1, p. 54-78, 2010.

CERVI, E. U. Métodos quantitativos nas ciências sociais: uma abordagem alternativa ao fetichismo dos números e ao debate com qualitativistas. Pesquisa Social, p. 125-143, 2009.

CHEN, S.; DHILLON, G. Interpreting Dimensions of Consumer Trust in E-commerce. Information Technology and Management, v. 4, p. 303-318, 2003.

CHO, N.; PARK, S. Development of electronic commerce user-consumer satisfaction index (ECUSI) for Internet shopping. Industrial Management \& Data Systems, 101, 2001. 400406.

CONSTANTINIDES, E. Influencing the online consumer's behavior: the Web experience. Internet Research, 24, n. 2, 2004. 111-126.

CORBITT, B.; THANASANKIT, T.; YI, H. Trust and e-commerce: a study of consumer perceptions. Electronic Commerce Research and Applications, 2, n. 3, 2003. 203-2015.

CORRITORE, C.; KRACHER, B.; WIEDENBECK, S. On-line trust: Concepts, evolving themes, a model. International Journal of Human Computer Studies, v. 58, n. 6, p. $737-$ $758,2003$.

DALZOCHIO, M. S.; HOFFMANN, W. Fez um bom negócio? Análise das estratégias publicitárias do classificado on-line bomnegocio.com. Revista Advérbio, v. 9, n. 18, 2014.

DELLAROCAS, C. The digitization of word of mouth: Promise and challenges of online feedback mechanisms. Management Science, 49, n. 10, 2003. 1407-1424.

DELONE, W. H.; MCLEAN, E. R. The DeLone and McLean Model of Information Systems Success: A Ten-Year Update. Journal of Management Information Systems, v. 19, n. 4, p. 9-30, 2003.

DEWALLY, M.; EDERINGTON, L. Reputation, Certification, Warranties , and Information as Remedies for Seller-Buyer Information Asymmetries : Lessons from the Online Comic Book Market. Journal of Business, 79, n. 2, 2006. 693-729. 
DUARTE, D.; PEREIRA, A.; MEIRA JR., W. Práticas de Comercialização em Mercados Eletrônicos. Workshop de Trabalhos de Iniciação Científica - WTIC/WebMedia '09: Proceedings of the 15th Brazilian Symposium on Multimedia and the Web. New York, USA: [s.n.]. 2009.

EBIT. Webshoppers - Edições de 2001 a 2013, 2014. Disponivel em: $<$ http://img.ebit.com.br/webshoppers/pdf/01a28_webshoppers.pdf $>$. Acesso em: 16 Maio 2016.

EBIT. Webshoppers $31^{\text {a }}$ Edição, 2016. Disponivel em: $<$ http://img.ebit.com.br/webshoppers/pdf/31_webshoppers.pdf>. Acesso em: 16 Maio 2016. EUROMONITOR INTERNATIONAL. Amazon vs Alibaba: The Fight to be the World's Largest Internet Retailer. [S.1.]. 2017.

FECOMERCIOSP. Dados e tendências sobre e-commerce, 2015. Disponivel em: $<$ http://pt.slideshare.net/tutufischer/dados-e-tendncias-sobre-ecommerce $>$. Acesso em: 25 maio 2016.

FUCHS, M.; EYBL, A.; HÖPKEN, W. Successfully selling accommodation packages at online auctions-The case of eBay Austria. Tourism Management, v. 32, n. 5, p. 1166-1175, 2011.

GEFFEN, D.; KARAHANNA, E.; STRAUB, D. W. Trust and TAM in online shopping: an integrated model. MIS Quarterly, 27, n. 1, 2003. 51-90.

GIL, A. C. Métodos e técnicas de pesquisa social. 6 ed. ed. São Paulo: Editora Atlas, 2008.

GREGG, D. G.; WALCZAK, S. Dressing Your Online Auction Business for Success: An Experiment Comparing Two eBay Businesses. MIS Quarterly, 32, n. 3, 2008. 653-670.

GREGG, D. G.; WALCZAK, S. The relationship between website quality, trust and price premiums at online auctions. Electronic Commerce Research, v. 10, n. 1, p. 1-25, 2010.

GRIEGER, M. Electronic marketplaces: A literature review and a call for supply chain management research. European journal of operational research, 144, 2003. 280-294.

HOFFMAN, D.; NOVAK, T.; CHATTERJEE, P. Commercial Scenarios for the Web: Opportunities and Challenges. Journal of Computer-Mediated Communication, v. 1, n. 3, 1995.

HONG, I.; CHO, H. he impact of consumer trust on attitudinal loyalty and purchase intentions in B2C e-marketplaces: Intermediary trust vs. seller trust. International Journal of Information Management, v. 31, n. 5, p. 469-479, 2011.

HOUSER, D.; WOODERS, J. Reputation in Auctions: Theory, and Evidence from eBay. Journal of Economics \& Management Strategy, 15, n. 2, 2006. 353-369.

HUI, X. et al. Reputation and Regulations: Evidence from eBay. Management Science, v. 62, n. 12, p. 3604-3616, 2016. 
INMON, W. H. Building the data warehouse. 4. ed. Indianapolis: Wiley Publishing, 2005.

JARVENPAA, S.; TRACTINSKY, N.; VITALE, M. Consumer trust in an Internet store. Information Technology and Management, v. 1, n. 1-2, p. 45-71, 2000.

JIN, G. Z.; KATO, A. Price, Quality and Reputation: Evidence from an Online Field Experiment. The RAND Journal of Economics, v. 37, n. 4, p. 983-1005, 2006.

JOLIVET, G.; JULLIEN, B.; POSTEL-VINAY, F. Reputation and prices on the e-market: Evidence from a major French platform. International Journal of Industrial Organization, v. 45, p. 59-75, March 2016.

KALAKOTA, R.; WHINSTON, A. B. Electronic Commerce: A Manager's Guide. 1 ed. ed. Boston: Addison-Wesley Professional, 1997.

KIM, M.-S.; AHN, J.-H. Management of trust in the e-marketplace: The role of the buyer's experience in building trust. Journal of Information Technology, v. 22, n. 2, p. 119-132, 2007.

KIM, M.-S.; AHN, J.-H. Management of trust in the e-marketplace: the role of the buyer's experience in building trust. Journal of Information Technology, v. 22, n. 2, p. 119-132, 2007.

LAUDON, K.; LAUDON, J. Sistemas de Informações Gerenciais. São Paulo: Pearson Prentice Hall, 2010.

LE, T. T. Pathways to leadership for business-to- business electronic marketplaces.

Electronic Markets, v. 12, n. 2, p. 112-119, 2002.

LEMES, A. D. et al. Um. olhar sobre o relacionamento e a fidelização do cliente em ecommerce: caso do site Mercado Livre. Borges, v. 4, n. 1, p. 85-110, 2004.

LI, D.; LI, J.; LIN, Z. Online consumer-to-consumer market in China-a comparative study of Taobao and eBay. Electronic Commerce Research and Applications, v. 7, n. 1, p. 55-67, 2008.

LI, et al. Are all signals equal? Investigating the differential effects of online signals on the sales performance of e-marketplace sellers. Information Technology \& People, v. 28, n. 3, p. 699-723, 2015.

LI, S.; SRINIVASAN, K.; SUN, B. Internet Auction Features as Quality Signals. Journal of Marketing, 73, n. 1, 2009. 75-92.

LIN, H.-F. The impact of website quality dimensions on customer satisfaction in the B2C ecommerce context. Total Quality Management \& Business Excellence, 18, n. 4, 2007. 363378.

LIN, H.-F. The Impact of Website Quality Dimensions on Customer Satisfaction in the B2C E-commerce Context. Total Quality Management \& Business Excellence, v. 18, n. 8, p. 363-378, 2010. 
LIVINGSTON, J. A. How valuable is a good reputation? A sample selection model of Internet auctions. The Review of Economics and Statistics, 87, n. 3, 2005. 453-465.

LUCKING-REILEY, D. et al. Pennies from ebay: the determiants of price in online auctions. The Journal of Industrial Economics, v. 55, n. 2, p. 223-233, June 2007.

LUMSDEN, J.; MACKAY, L. How does personality affect trust in B2C e-commerce? 8th International Conference on Electronic Commerce: The New E-Commerce: Innovations for Conquering Current Barriers, Obstacles and Limitations to Conducting Successful Business on the Internet. Fredericton, Canadá: [s.n.]. 2006. p. 471-481.

MARANZATO, R. et al. Feature Extraction for Fraud Detection in Electronic Marketplaces. LA-WEB '09. Latin American. Yucatan, Mexico: [s.n.]. 2009.

MARANZATO, R. et al. Fraud detection in reputation systems in e-markets using logistic regression and stepwise optimization. ACM SIGAPP Applied Computing Review, v. 11, n. 1, p. 14-26, Junho 2010.

MCLEAN, E. R.; DELONE, W. H. The DeLone and McLean model of information systems success: a ten-year update. Journal of management information systems, 19, n. 4, 2003. 930 .

MELNIK, M.; ALM, J. Reputation, information signals, and willingness to pay for heterogeneous goods in online auctions, 2003.

MELNIK, M.; ALM, J. Seller Reputation, Information Signals, and Prices for Heterogeneous Coins on eBay. Southern Economic Journal, 72, n. 2, 2005.

MERCADO LIVRE. Palestra FastCommerce, 2014. Disponivel em: $<$ https://www.fastcommerce.com.br/dnload/PalestraMercado Livre24042014.pdf $>$. Acesso em: 25 Maio 2016.

MERCADO LIVRE. MercadoLibre Developers, 2016. Disponivel em: $<$ http://developers.mercadolibre.com/pt-br/>. Acesso em: 2 Jun 2016.

NASDAQ. Amazon Vs. Alibaba: GMV, Revenue \& EBITDA, 2016. Disponivel em: $<$ http://www.nasdaq.com/article/amazon-vs-alibaba-gmv-revenue-ebitda-cm605342>. Acesso em: 28 Maio 2016.

NETO, J. Q. F.; CORBETT, C.; BLOEMHOF, J. Market prices of remanufactured, used and new items: Evidence from eBay. International Journal of Production Economics, v. 171, p. 371-380, 2016.

NEWBERRY, P. W. The effect of competition on eBay. International Journal of Industrial Organization, 40, 2015. 107-118.

NEXTECOMMERCE. B2W fatura quase 25\% do e-commerce brasileiro, 2015. Disponivel em: <http://nextecommerce.com.br/b2w-fatura- quase-25- do-e- commerce- brasileiro/>. Acesso em: 28 Maio 2016. 
NORRIS, B.; HARUVY, E.; RAM, R. Seller rating, price, and default in online auctions. Journal of Interactive Marketing, 18, n. 4, 2004. 37-50.

ONUR, I. Bidding behavior in dynamic auction settings: An empirical analysis of eBay. Electronic Commerce Research and Applications, v. 9, n. 2, p. 103-110, 2010.

PAUL, P.; DIMOKA, A. The nature and role of feedback text comments in online marketplaces: implications for trust building, price premiums, and seller differentiation. Information Systems Research, 17, n. 4, 2006. 392-414.

PAVLOU, P. Consumer Acceptance of Electronic Commerce: Integrating Trust and Risk with the Technology Acceptance Model. nternational Journal of Electronic Commerce, v. 7, n. 3, p. 101-134, 2003.

PAVLOU, P. A.; GEFEN, D. Building effective online marketplaces with institution-based trust. Information systems research, v. 15, n. 1, p. 37-59, 2004.

PEREIRA, A. C. M. et al. Selling Practices in Online Fixed-price Marketplaces. Applications and the Internet, 2009. SAINT '09. Ninth Annual International Symposium on. Bellevue, EUA: IEEE. 2009a. p. 71-77.

PEREIRA, A. C. M. et al. Assessing success factors of selling practices in electronic marketplaces. International Conference on Management of Emergent Digital EcoSystems, MEDES '09. Lyon, France: [s.n.]. 2009b. p. 261-268.

PEREIRA, A. C. M. et al. Evaluating success factors of selling practices in electronic marketplaces. International Journal of Electronic Business, v. 9, n. 5/6, p. 454-483, 2011.

PRZEPIORKA, W. Buyers Pay For and Sellers Invest in a Good Reputation: More Evidence from eBay. The Journal of Socio-Economics, v. 42, p. 31-42, 2013.

RAMOS, M. P. Métodos Quantitativos e Pesquisa em Ciências Sociais: Lógica e Utilidade do Uso da Quantificação nas Explicações dos Fenômenos Sociais. Mediações - Revista de Ciências Sociais, v. 18, n. 1, p. 55-65, 2013.

RESNICK, P. et al. The value of reputation on eBay: A controlled experiment. Experimental Economics, 9, n. 2, 2006. 79-101.

RITALA, P.; GOLNAM, A.; WEGMANN, A. Coopetition-based business models: The case of Amazon.com. Industrial Marketing Management, v. 43, n. 2, p. 236-249, 2014.

RYAN, J.; SUN, D.; ZHAO, X. Competition and Coordination in Online Marketplaces. Production and Operations Management, v. 21, n. 6, p. 997-1014, 2012.

SALAM, A. F. et al. Trust in E-Commerce. Communications of the ACM, 48, n. 2, 2005. 73-77.

SCHNEIDER, G. Electronic Commerce. Boston: Cengage Learning, 2011. 
SILVA, E. L. D.; MENEZES, E. M. Metodologia da Pesquisa e Elaboração de

Dissertação. 4 ed. ed. Florianópolis: [s.n.], 2005.

TADELIS, S. Reputation and Feedback Systems in Online Platform Markets. Annual Review of Economics, v. 8, p. 321-340, 2016.

TEO, T.; LIU, J. Consumer trust in e-commerce in the United States, Singapore and China. Omega, v. 35, n. 1, p. 22-38, 2007.

THOMPSON, T. S.; LIU, J. Consumer trust in e-commerce in the United States, Singapore and China. Omega, 35, n. 1, 2007.

TURBAN, E. et al. Electronic Commerce: A Managerial and Social Networks Perspective. 8 ed. ed. [S.1.]: Springer, 2015.

UTZ, S.; MATZAT, U.; CHRIS, S. Online Reputation Systems: The Effects of Feedback Comments and Reactions on Building. International Journal of Electronic Commerce, 13, n. 3, 2009. 95-118.

VERHAGEN, T.; SELMAR, M.; YAO-HUA, T. Perceived risk and trust associated with purchasing at electronic marketplaces. European Journal of Information Systems, v. 15, n. 6, p. 542-555, 2006.

VILA, N.; KUSTER, I. Consumer feelings and behaviours towards well designed websites. Information and Management, v. 48, n. 4-5, p. 166-177, 2011.

WANG, S.; ARCHER, N. P. Electronic marketplace definition and classification: literature review and clarifications. Enterprise Information Systems, 1, n. 1, 2007. 89-112.

WANG, Y. D.; EMURIAN, H. H. An overview of online trust: Concepts, elements, and implications. Computers in Human Behavior, 21, n. 1, 2005. 105-125.

ZHANG, H.; LI, H. Factors affecting payment choices in online auctions: A study of eBay traders. Decision Support Systems, 42, n. 2, 2006. 1076-1088.

ZHANG, J. The roles of players and reputation: Evidence from eBay online auctions. Decision Support Systems, v. 42, n. 3, p. 1800-1818, 2006.

ZWASS, V. Electronic Commerce: Structures and Issues. International Journal of Electronic Commerce, v. 1, n. 1, p. 3-23, 1996. 


\section{APÊNDICES}

APÊNDICE A - Dados do Anúncio

APÊNDICE B - Dados do Vendedor 


\section{APÊNDICE A - Dados do Anúncio}

\begin{tabular}{|c|c|c|}
\hline Coluna & Valor de Exemplo & Comentário \\
\hline id & 11230 & $\begin{array}{l}\text { Código interno único que identifica esta } \\
\text { linha na tabela. }\end{array}$ \\
\hline id_ad & MLB825608731 & $\begin{array}{l}\text { Código único de identificação do anúncio } \\
\text { no Mercado Livre. No banco de dados } \\
\text { cada anúncio possui vários registros (um } \\
\text { para cada coleta). }\end{array}$ \\
\hline etl_date & 2017-01-10 01:00:00 & $\begin{array}{l}\text { Data em que os dados foram coletados. } \\
\text { Cada anúncio possui um registro para cada } \\
\text { data, mostrando como se encontrava o } \\
\text { anúncio naquele momento. Na prática, há } \\
\text { uma coluna etl_id e a data da coleta está } \\
\text { salva em outra tabela referenciada por este } \\
\text { número. A data foi inserida diretamente } \\
\text { aqui para facilitar o entendimento. }\end{array}$ \\
\hline Id_site & MLB & $\begin{array}{l}\text { Código único de identificação do país no } \\
\text { Mercado Livre. Como estamos analisando } \\
\text { apenas o Brasil, todos os anúncios } \\
\text { possuem o código MLB. }\end{array}$ \\
\hline title & $\begin{array}{l}\text { Iphone } 6 \text { Apple } 16 \mathrm{gb} \\
\text { Cinza Espacial 4g } \\
\text { Tela 4,7 - Retina Câm }\end{array}$ & Título do anúncio \\
\hline seller_id & 98191390 & $\begin{array}{l}\text { Código único de identificação do vendedor } \\
\text { no Mercado Livre }\end{array}$ \\
\hline category & MLB169490 & $\begin{array}{l}\text { Código único de identificação da categoria } \\
\text { (produto) no Mercado Livre }\end{array}$ \\
\hline id_official_store & Nulo & $\begin{array}{l}\text { Código único de identificação da loja } \\
\text { oficial do vendedor no Mercado Livre. A } \\
\text { maioria dos vendedores não possuem. }\end{array}$ \\
\hline
\end{tabular}




\begin{tabular}{|c|c|c|}
\hline price & 2350 & $\begin{array}{l}\text { Preço que o produto está sendo ofertado no } \\
\text { momento }\end{array}$ \\
\hline currency & BRL & $\begin{array}{l}\text { Código único de identificação da moeda } \\
\text { utilizada na negociação. Como estamos } \\
\text { analisando apenas o Brasil, todos os } \\
\text { anúncios possuem o código BRL. }\end{array}$ \\
\hline qty_start & 1 & $\begin{array}{l}\text { Não é exibido para o comprador. É a } \\
\text { quantidade de itens disponíveis neste } \\
\text { anúncio assim que ele foi publicado. }\end{array}$ \\
\hline $\begin{array}{l}\text { available_quantit } \\
\mathrm{y}\end{array}$ & 1 & $\begin{array}{l}\text { Não é exibido para o comprador. É a } \\
\text { quantidade de itens disponíveis neste } \\
\text { anúncio no momento atual. }\end{array}$ \\
\hline sold_quantity & 0 & $\begin{array}{l}\text { Exibido para o comprador. É a quantidade } \\
\text { de itens já vendidos por este anúncio até a } \\
\text { data atual. }\end{array}$ \\
\hline buy_mode & buy_it_now & $\begin{array}{l}\text { Informa se o anúncio é uma venda normal } \\
\text { (preço fixo) ou um leilão. Todos os } \\
\text { anúncios de leilão foram desconsiderados e } \\
\text { por isso todos os anúncios possuem o tipo } \\
\text { buy_it_now. }\end{array}$ \\
\hline ad_type & gold_special & $\begin{array}{l}\text { Identifica se o vendedor está pagando } \\
\text { alguma taxa para maior exposição do } \\
\text { anúncio. Valores possíveis: free (gratuito), } \\
\text { gold_pro (clássico) e gold_special } \\
\text { (preemium). }\end{array}$ \\
\hline start_time & 2016-12-30 23:07:17 & Data que o anúncio foi publicado. \\
\hline stop_time & 2036-12-25 23:07:17 & $\begin{array}{l}\text { Data que o anúncio foi finalizado. } \\
\text { Enquanto o anúncio estiver ativo, o valor } \\
\text { do campo é uma data futura distante. } \\
\text { Quando o anúncio é finalizado, o campo é } \\
\text { atualizado com a data correta. }\end{array}$ \\
\hline item_condition & new & $\begin{array}{l}\text { Novo ou usado. Valores possíveis: new e } \\
\text { used. }\end{array}$ \\
\hline
\end{tabular}




\begin{tabular}{|c|c|c|}
\hline link & $\begin{array}{l}\text { http://produto.Mercad } \\
\text { o Livre.com.br/MLB- } \\
\text { 825608731-iphone-6- } \\
\text { apple-16gb-cinza- } \\
\text { espacial-4g-tela-47- } \\
\text { retina-cm-_JM }\end{array}$ & Endereço da página do anúncio \\
\hline thumbnail & $\begin{array}{l}\text { http://mlb-s1- } \\
\text { p.mlstatic.com/14351 } \\
\text { 5- } \\
\text { MLB25255561136_1 } \\
\text { 22016-I.jpg }\end{array}$ & $\begin{array}{l}\text { Endereço da miniatura da principal } \\
\text { imagem do anúncio. }\end{array}$ \\
\hline video & Nulo & Endereço do vídeo presente no anúncio. \\
\hline mercadopago & Verdadeiro & $\begin{array}{l}\text { Indica se o vendedor aceita pagamento via } \\
\text { MercadoPago. Praticamente todos os } \\
\text { anúncios aceitam MercadoPago. }\end{array}$ \\
\hline delivery_mode & me2 & $\begin{array}{l}\text { Indica se o vendedor pode enviar o produto } \\
\text { utilizando MercadoEnvio para este } \\
\text { anúncio. }\end{array}$ \\
\hline delivery_person & Falso & $\begin{array}{l}\text { Indica se o comprador pode retirar o } \\
\text { produto pessoalmente. }\end{array}$ \\
\hline delivery_free & Falso & $\begin{array}{l}\text { Indica se o frete é gratuito (pago pelo } \\
\text { vendedor). }\end{array}$ \\
\hline ad_status & Active & $\begin{array}{l}\text { Situação do anúncio no momento. } \\
\text { Possíveis valores são: ativo (active), } \\
\text { finalizado (closed), pausado pelo vendedor } \\
\text { (paused), em revisão pelo Mercado Livre } \\
\text { (under_review - geralmente são casos de } \\
\text { fraude) e inativo (inactive). }\end{array}$ \\
\hline warranty & Nulo & $\begin{array}{l}\text { Campo textual com a garantia oferecida } \\
\text { pelo vendedor. No caso deste anúncio, não } \\
\text { foi oferecida garantia. }\end{array}$ \\
\hline date_create & 2016-12-30 23:07:17 & $\begin{array}{l}\text { Data que o anúncio foi criado. Geralmente } \\
\text { coincide com a data de publicação, mas é }\end{array}$ \\
\hline
\end{tabular}




\begin{tabular}{|c|c|c|}
\hline & & $\begin{array}{l}\text { possível criar o anúncio em um momento e } \\
\text { deixar para publicá-lo depois. }\end{array}$ \\
\hline date_last_update & 2017-01-01 05:26:36 & Data de última atualização do anúncio. \\
\hline qty_photos & 1 & Número do total de fotos no anúncio. \\
\hline photo_1_id & $\begin{array}{l}\text { 143515- } \\
\text { MLB25255561136_1 } \\
22016\end{array}$ & $\begin{array}{l}\text { Código único de identificação da foto no } \\
\text { Mercado Livre. }\end{array}$ \\
\hline photo_1_url & $\begin{array}{l}\text { http://mlb-s1- } \\
\text { p.mlstatic.com/14351 } \\
\text { 5- } \\
\text { MLB25255561136_1 } \\
\text { 22016-O.jpg }\end{array}$ & Endereço da foto. \\
\hline photo_1_size & $500 \times 375$ & Tamanho original (em pixels) da foto. \\
\hline photo_1_maxsize & $912 \times 684$ & $\begin{array}{l}\text { Tamanho máximo que o Mercado Livre } \\
\text { vai permitir esticar a foto em sua exibição. }\end{array}$ \\
\hline photo_2_id & Nulo & $\begin{array}{l}\text { Campos a seguir não estão preenchidos } \\
\text { pois o anúncio possui apenas uma foto. }\end{array}$ \\
\hline photo_2_url & Nulo & \\
\hline photo_2_size & Nulo & \\
\hline photo_2_maxsize & Nulo & \\
\hline photo_3_id & Nulo & \\
\hline photo_3_url & Nulo & \\
\hline photo_3_size & Nulo & \\
\hline photo_3_maxsize & Nulo & \\
\hline photo_4_id & Nulo & \\
\hline photo_4_url & Nulo & \\
\hline photo_4_size & Nulo & \\
\hline photo_4_maxsize & Nulo & \\
\hline photo_5_id & Nulo & \\
\hline photo_5_url & Nulo & \\
\hline photo_5_size & Nulo & \\
\hline
\end{tabular}




\begin{tabular}{|c|c|c|}
\hline photo_5_maxsize & Nulo & \\
\hline photo_6_id & Nulo & \\
\hline photo_6_url & Nulo & \\
\hline photo_6_size & Nulo & \\
\hline photo_6_maxsize & Nulo & \\
\hline id_description & $\begin{array}{l}\text { MLB726116606- } \\
979743505\end{array}$ & $\begin{array}{l}\text { Código único de identificação da descrição } \\
\text { deste anúncio no Mercado Livre. }\end{array}$ \\
\hline description_html & $\begin{array}{l}<\text { h3 style="text-align: } \\
\text { center;"><span } \\
\text { style="font-size: } \\
\text { large;">iPhone } 6 \\
\text { Apple 16GB Cinza } \\
\text { Espacial 4G Tela 4,7" } \\
\text { - Retina Câmera 8MP } \\
\text { iOS } 8 \text { Proc. M8 Bivolt } \\
\text {-Cinza } \\
\text { Espacial</span></h3> } \\
<\text { p style="text-align: } \\
\text { center;"> ... }\end{array}$ & $\begin{array}{l}\text { Conteúdo em HTML da descrição. Na } \\
\text { prática este conteúdo foi salvo em uma } \\
\text { tabela separada. Ele está listado nesta } \\
\text { relação para facilitar o entendimento. Por } \\
\text { questões práticas, o conteúdo na coluna de } \\
\text { exemplo foi cortado e está exibindo apenas } \\
\text { as primeiras linhas. }\end{array}$ \\
\hline description_plain & Nulo & $\begin{array}{l}\text { Conteúdo em texto puro da descrição. Na } \\
\text { prática este conteúdo foi salvo em uma } \\
\text { tabela separada. Ele está listado nesta } \\
\text { relação para facilitar o entendimento. É } \\
\text { permitido ao vendedor, mas não } \\
\text { obrigatório, informar um conteúdo sem } \\
\text { formatação para a descrição. Este conteúdo } \\
\text { é exibido em dispositivos que não exibem } \\
\text { o HTML (ex.: o aplicativo do Mercado } \\
\text { Livre). }\end{array}$ \\
\hline city_id & BR-RJ-01 & $\begin{array}{l}\text { Código único de identificação da cidade no } \\
\text { Mercado Livre }\end{array}$ \\
\hline city & Rio de Janeiro & Cidade de onde será enviado o produto \\
\hline
\end{tabular}




\begin{tabular}{|l|l|l|}
\hline state_id & BR-RJ & $\begin{array}{l}\text { Código único de identificação do estado no } \\
\text { Mercado Livre }\end{array}$ \\
\hline state & Rio de Janeiro & Estado de onde será enviado o produto \\
\hline item_visits & \multirow{2}{*}{630} & $\begin{array}{l}\text { Quantidade de visitas que o anúncio } \\
\text { recebeu desde sua publicação até a data } \\
\text { atual. Na prática esta informação está em } \\
\text { uma tabela separada. Ela está exposta na } \\
\text { mesma tabela aqui para facilitar o } \\
\text { entendimento. }\end{array}$ \\
\hline etl_cicle & search & $\begin{array}{l}\text { Identifica se o anúncio foi capturado na } \\
\text { primeira parte do processo (busca por } \\
\text { anúncios por categoria) ou na etapa } \\
\text { seguinte (busca por anúncios que estavam } \\
\text { no dia anterior e não retornaram na busca } \\
\text { deste dia). Na prática, há uma coluna etl_id } \\
\text { e esta informação está salva em outra } \\
\text { tabela, sendo referenciada por este número. } \\
\text { A informação está exposta aqui para } \\
\text { facilitar o entendimento. }\end{array}$ \\
\hline
\end{tabular}

APÊNDICE B - Dados do Vendedor

\begin{tabular}{|l|l|l|}
\hline Coluna & Valor de Exemplo & \multicolumn{1}{|c|}{ Comentário } \\
\hline id & 6915 & $\begin{array}{l}\text { Código interno único que identifica esta } \\
\text { linha na tabela. }\end{array}$ \\
\hline & $\begin{array}{l}\text { Data em que os dados foram coletados. } \\
\text { Cada vendedor possui um registro para } \\
\text { cada data, mostrando como se encontrava } \\
\text { o anúncio naquele momento. Na prática, há } \\
\text { uma coluna etl_id na tabela e a data da } \\
\text { coleta está salva em outra tabela } \\
\text { referenciada por este número. A data foi }\end{array}$ \\
\hline
\end{tabular}




\begin{tabular}{|c|c|c|}
\hline & & $\begin{array}{l}\text { inserida diretamente aqui para facilitar o } \\
\text { entendimento. }\end{array}$ \\
\hline nickname & $\begin{array}{l}\text { MAGAZINEATA } \\
\text { CADOCELL }\end{array}$ & Nome do usuário do vendedor. \\
\hline date_register & $\begin{array}{l}2006-09-14 \\
17: 50: 26\end{array}$ & Data de criação da conta do vendedor. \\
\hline country & BR & $\begin{array}{l}\text { País do vendedor. Como estamos } \\
\text { considerando apenas o Mercado Livre } \\
\text { brasileiro, todos os vendedores possuem } \\
\text { 'BR'. }\end{array}$ \\
\hline seller_type & normal & $\begin{array}{l}\text { Tipo do vendedor. Valores possíveis são } \\
\text { 'normal' ou 'brand' (marca). Os vendeores } \\
\text { 'brand' são aqueles classificados como loja } \\
\text { oficial. Quase todos os vendedores neste } \\
\text { trabalho são do tipo 'normal'. }\end{array}$ \\
\hline $\log 0$ & Nulo & $\begin{array}{l}\text { Endereço da imagem da logomarca do } \\
\text { vendedor, caso este seja uma loja oficial. }\end{array}$ \\
\hline points & 20 & $\begin{array}{l}\text { Soma de todas as avaliações positivas } \\
\text { subtraído das avaliações negativas } \\
\text { recebidas pelo usuário recebidas pelo } \\
\text { usuário como vendedor ou comprador. } \\
\text { Esta informação não é exibida na página } \\
\text { do anúncio, apenas no perfil do vendedor. } \\
\text { No caso deste usuário, } 19 \text { pontos foram em } \\
\text { compras que ele realizou e apenas um foi } \\
\text { com venda realizada. }\end{array}$ \\
\hline rep_level & Nulo & $\begin{array}{l}\text { Classificação do vendedor no termômetro, } \\
\text { baseado em seu histórico de transações. } \\
\text { Valores possíveis: Nulo, 1_red, 2_range, } \\
\text { 3_yellow, 4_light_green, 5_green }\end{array}$ \\
\hline
\end{tabular}




\begin{tabular}{|l|l|l|}
\hline rep_power & Nulo & $\begin{array}{l}\text { Classificação do vendedor como } \\
\text { MercadoLíder. Valores possíveis: Nulo, } \\
\text { silver, gold e platinum. }\end{array}$ \\
\hline rep_trans_total & 1 & $\begin{array}{l}\text { Quantidade de transações realizadas como } \\
\text { vendedor (vendas). }\end{array}$ \\
\hline rep_trans_complete & 1 & $\begin{array}{l}\text { Quantidade de vendas realizadas que } \\
\text { foram concluídas com sucesso. }\end{array}$ \\
\hline rep_trans_cancel & 0 & $\begin{array}{l}\text { Quantidade de vendas iniciadas mas não } \\
\text { concluídas, pois alguma das partes desistiu } \\
\text { (ex: comprador clicou em comprar, mas } \\
\text { não pagou). A soma de rep_trans_complete } \\
\text { com rep_trans_cancel é igual ao } \\
\text { rep_trans_total. }\end{array}$ \\
\hline rep_trans_point_pos & 1 & $\begin{array}{l}\text { Percentual de vendas realizadas cuja } \\
\text { avaliação foi positiva. Varia de 0 a 1. }\end{array}$ \\
\hline rep_trans_point_neu & 0 & $\begin{array}{l}\text { Percentual de vendas realizadas cuja } \\
\text { avaliação foi neutra. Varia de 0 a 1. }\end{array}$ \\
\hline & 0 & $\begin{array}{l}\text { Percentual de vendas realizadas cuja } \\
\text { avaliação foi negativa. Varia de 0 a 1. }\end{array}$ \\
\hline
\end{tabular}

